Prepared in cooperation with the Rosebud Sioux Tribe

\title{
Simulated Groundwater Flow in the Ogallala and Arikaree Aquifers, Rosebud Indian Reservation Area, South Dakota-Revisions with Data Through Water Year 2008 and Simulations of Potential Future Scenarios
}

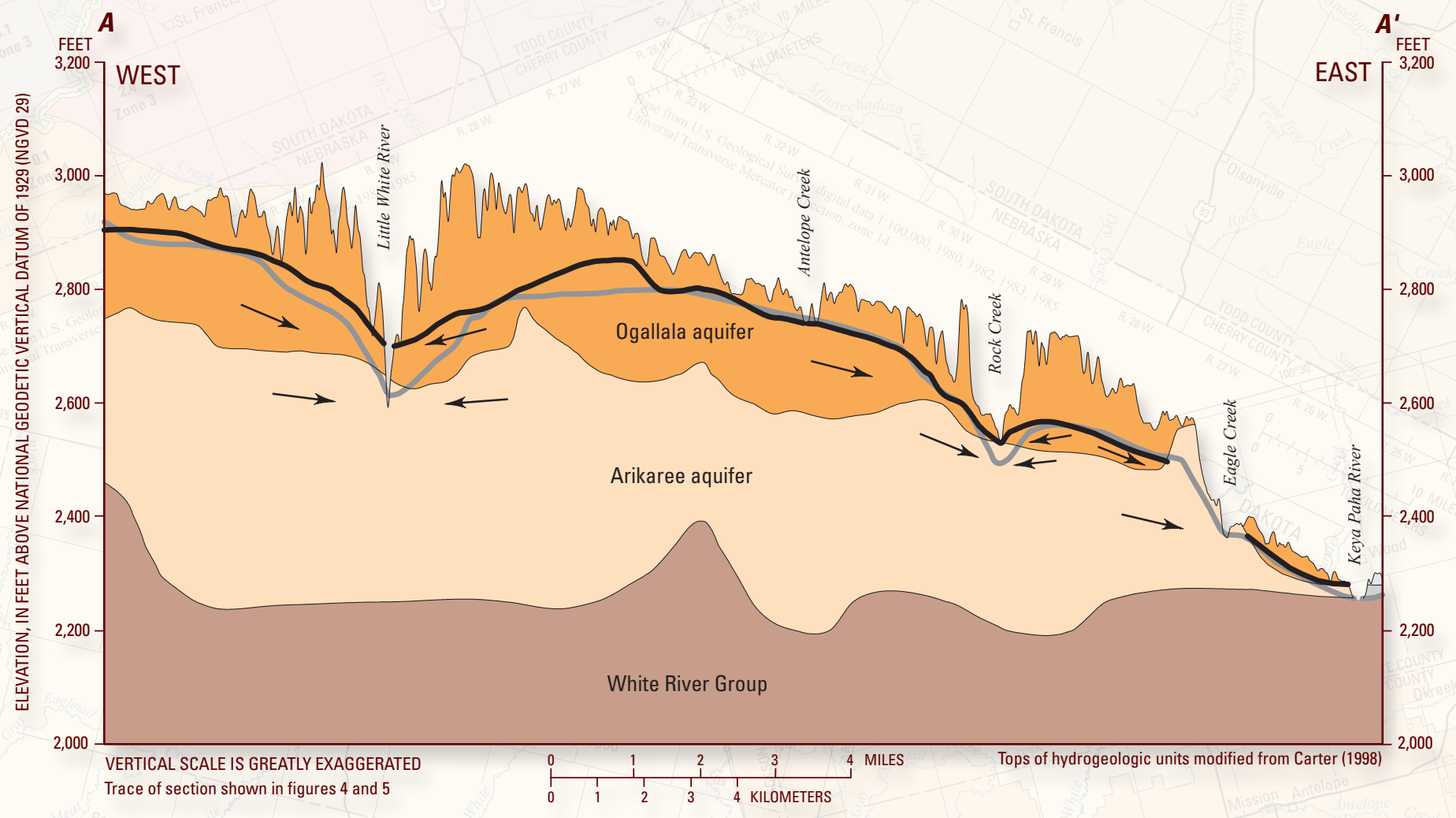

Scientific Investigations Report 2010-5105 
EXPLANATION FOR THE COVER ILLUSTRATION (figure 6 from this report)

\footnotetext{
Average hydraulic head in Arikaree aquifer, water years 1979-98

Average hydraulic head in Ogallala aquifer, water years 1979-98

$\longrightarrow$ General direction of groundwater flow
} 


\section{Simulated Groundwater Flow in the Ogallala and Arikaree Aquifers, Rosebud Indian Reservation Area, South Dakota-Revisions with Data Through Water Year 2008 and Simulations of Potential Future Scenarios}

By Andrew J. Long and Larry D. Putnam

Prepared in cooperation with the Rosebud Sioux Tribe

Scientific Investigations Report 2010-5105 


\title{
U.S. Department of the Interior \\ KEN SALAZAR, Secretary \\ U.S. Geological Survey \\ Marcia K. McNutt, Director
}

\section{U.S. Geological Survey, Reston, Virginia: 2010}

\author{
For more information on the USGS — the Federal source for science about the Earth, its natural and living resources, \\ natural hazards, and the environment, visit http://www.usgs.gov or call 1-888-ASK-USGS \\ For an overview of USGS information products, including maps, imagery, and publications, \\ visit http://www.usgs.gov/pubprod \\ To order this and other USGS information products, visit http://store.usgs.gov
}

Any use of trade, product, or firm names is for descriptive purposes only and does not imply endorsement by the U.S. Government.

Although this report is in the public domain, permission must be secured from the individual copyright owners to reproduce any copyrighted materials contained within this report.

Suggested citation:

Long, A.J., and Putnam, L.D., 2010, Simulated groundwater flow in the Ogallala and Arikaree aquifers, Rosebud Indian Reservation area, South Dakota-Revisions with data through water year 2008 and simulations of potential future scenarios: U.S. Geological Survey Scientific Investigations Report 2010-5105, 64 p. 


\section{Contents}

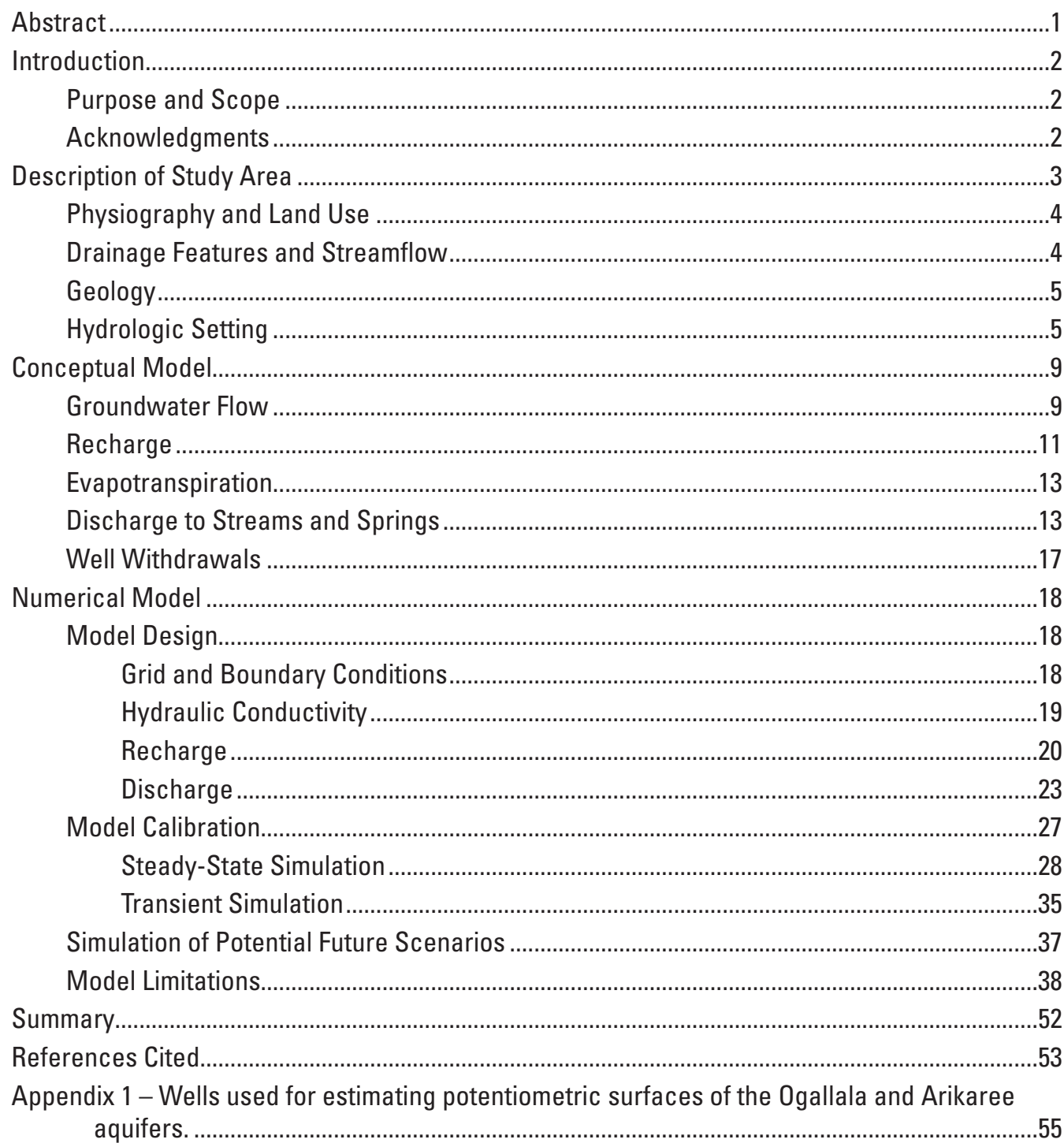

\section{Figures}

1-5. Maps showing:

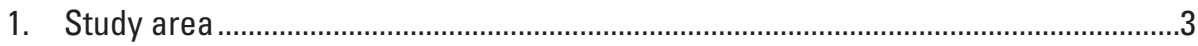

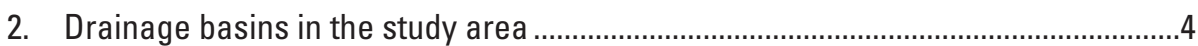

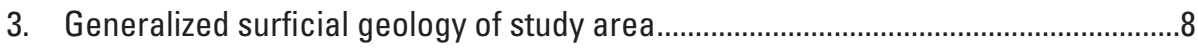

4. Estimated average potentiometric surface of the Ogallala aquifer ..........................10

5. Estimated average potentiometric surface of the Arikaree aquifer ........................11

6. Cross section showing relation between hydraulic head, hydrogeologic units, and

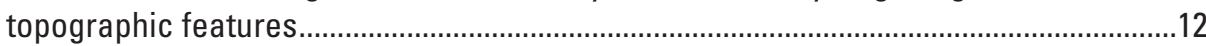

7-16. Maps showing:

7. Streamflow measurement sites for seepage runs during 1999 and $2006 \ldots \ldots \ldots \ldots . . . . .14$

8. Recharge areas and locations of water-supply wells.............................................19 
9. Cell types in the Ogallala aquifer (layer 1), observation wells completed in the Ogallala aquifer, and row and column widths for the Ogallala and Arikaree aquifers.

10. Cell types in the Arikaree aquifer (layer 2) and observation wells completed in the

Arikaree aquifer .....

11. Estimated horizontal hydraulic conductivity of the Ogallala aquifer, in feet per day. $\ldots 22$

12. Estimated horizontal hydraulic conductivity of the Arikaree aquifer, in feet per day.

13. Estimated vertical hydraulic conductivity $(K)$, in feet per day, for the Arikaree aquifer in five parameter zones where overlain by the Ogallala aquifer

14. River cells, evapotranspiration zones, spring cells, and water-supply wells in the Ogallala and Arikaree aquifers.

15. Potentiometric surface of the Ogallala aquifer for steady-state simulation ............30

16. Potentiometric surface of the Arikaree aquifer for steady-state simulation............31

17-20. Graphs showing:

17. Histogram of residuals of average observed and steady-state simulated hydraulic head for 383 wells, water years 1979-98

18. Linear regression of average observed and simulated steady-state hydraulic heads for 383 wells, water years 1979-98.

19. Relative parameter sensitivities as a fractional change in the objective function (sum of the squared weighted residuals) resulting from a 5-percent change in parameter values.

20. Relative sensitivities of parameter classes as a percent change in the objective function (sum of the squared weighted residuals) resulting from a 5-percent change in parameter values

21-23. Hydrographs showing:

21. Simulated and observed data for State observation wells for calibrated transient model

22. Simulated and observed data for Tribal observation wells for calibrated transient model

23. Differences of water levels in wells between results of the calibrated model and the assumed potential drought scenario for the 30 -year simulation period for selected sites for the Ogallala aquifer

24. Map showing simulated potentiometric surfaces for the calibrated model and the drought scenario at the end of a 30 -year simulation period for the Ogallala aquifer .....49

25. Hydrographs showing the differences in water levels in wells between results of the calibrated model and the scenario of pumping increased by 50 percent for the 30-year simulation period for selected sites for the Ogallala aquifer....

26. Map showing simulated potentiometric surfaces for the calibrated model and the scenario of pumping increased by 50 percent at the end of a 30 -year simulation period for the Ogallala aquifer 


\section{Tables}

1. Generalized stratigraphic column showing geologic units and hydrologic characteristics

2. Estimated maximum evapotranspiration rate during summer stress periods, water years 1979-2008

3. Measured streamflow at selected sites during seepage runs during 1999 and 2006 . Estimates of base flow for each drainage basin are shown

4. Estimated groundwater withdrawals for irrigation and public supply in the study area, 1979-2008 .17

5. Revisions to the model described by Long and others (2003) ..........................................18

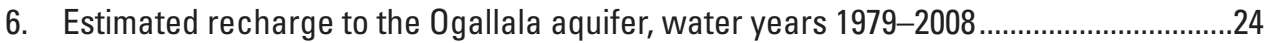

7. Selected data for Tribal observation wells in the study area.............................................28

8. Selected data for State observation wells in the study area ............................................29

9. Comparison of steady-state simulated and estimated base flows for six surface-water

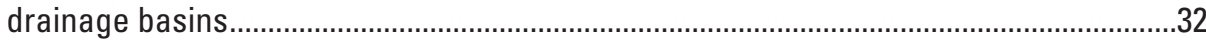

10. Parameter values estimated by inverse modeling for the steady-state simulation ........34

11. Water budget for steady-state simulation compared with the water budget from Long

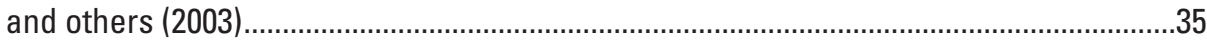

12. Parameter correlation matrix showing correlation coefficients for all parameter pair

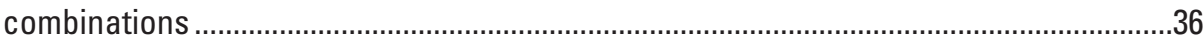

13. Comparison of estimated hydraulic conductivity values for the model described by Long and others (2003) and the revised model described in this report 


\section{Conversion Factors, Abbreviations, and Datums}

\begin{tabular}{|c|c|c|}
\hline Multiply & By & To obtain \\
\hline \multicolumn{3}{|c|}{ Length } \\
\hline inch (in.) & 2.54 & centimeter $(\mathrm{cm})$ \\
\hline inch (in.) & 25.4 & millimeter $(\mathrm{mm})$ \\
\hline foot (ft) & 0.3048 & meter $(\mathrm{m})$ \\
\hline mile (mi) & 1.609 & kilometer (km) \\
\hline mile, nautical (nmi) & 1.852 & kilometer (km) \\
\hline \multicolumn{3}{|c|}{ Area } \\
\hline acre & 4,047 & square meter $\left(\mathrm{m}^{2}\right)$ \\
\hline acre & 0.4047 & hectare (ha) \\
\hline acre & 0.4047 & square hectometer $\left(\mathrm{hm}^{2}\right)$ \\
\hline acre & 0.004047 & square kilometer $\left(\mathrm{km}^{2}\right)$ \\
\hline square mile $\left(\mathrm{mi}^{2}\right)$ & 259.0 & hectare (ha) \\
\hline square mile $\left(\mathrm{mi}^{2}\right)$ & 2.590 & square kilometer $\left(\mathrm{km}^{2}\right)$ \\
\hline \multicolumn{3}{|c|}{ Volume } \\
\hline acre-foot (acre-ft) & 1,233 & cubic meter $\left(\mathrm{m}^{3}\right)$ \\
\hline acre-foot (acre-ft) & 0.001233 & cubic hectometer $\left(\mathrm{hm}^{3}\right)$ \\
\hline \multicolumn{3}{|c|}{ Flow rate } \\
\hline foot per day (ft/d) & 0.3048 & meter per day $(\mathrm{m} / \mathrm{d})$ \\
\hline cubic foot per second $\left(\mathrm{ft}^{3} / \mathrm{s}\right)$ & 0.02832 & cubic meter per second $\left(\mathrm{m}^{3} / \mathrm{s}\right)$ \\
\hline gallon per minute (gal/min) & 0.06309 & liter per second (L/s) \\
\hline inch per year (in/yr) & 25.4 & millimeter per year (mm/yr) \\
\hline \multicolumn{3}{|c|}{ Hydraulic conductivity } \\
\hline foot per day (ft/d) & 0.3048 & meter per day (m/d) \\
\hline
\end{tabular}

Temperature in degrees Celsius $\left({ }^{\circ} \mathrm{C}\right)$ may be converted to degrees Fahrenheit $\left({ }^{\circ} \mathrm{F}\right)$ as follows:

$$
{ }^{\circ} \mathrm{F}=\left(1.8 \mathrm{x}^{\circ} \mathrm{C}\right)+32
$$

Temperature in degrees Fahrenheit $\left({ }^{\circ} \mathrm{F}\right)$ may be converted to degrees Celsius $\left({ }^{\circ} \mathrm{C}\right)$ as follows:

$$
{ }^{\circ} \mathrm{C}=\left({ }^{\circ} \mathrm{F}-32\right) / 1.8
$$

Vertical coordinate information is referenced to the National Geodetic Vertical Datum of 1929 (NGVD 29).

Horizontal coordinate information is referenced to the North American Datum of 1927 (NAD 27).

Altitude, as used in this report, refers to distance above the vertical datum.

Water year is the 12-month period, October 1 through September 30, and is designated by the calendar year in which it ends. 


\section{Abbreviations and Acronyms}

K

$\mathrm{R}^{2}$

RMSE

SWUDS

USGS hydraulic conductivity

coefficient of determination

root mean square error

U.S. Geological Survey's Site-Specific Water-Use Data System

U.S. Geological Survey

\section{Well-Numbering System}

The well number consists of the township number, followed by " $\mathrm{N}$," the range number followed by " $\mathrm{W}$," and the section number followed by a maximum of four uppercase letters that indicate, respectively, the 160-, 40-, 10-, and 2 $1 / 2$-acre tract in which the well is located. These letters are assigned in a counterclockwise direction beginning with "A" in the northeast quarter. A serial number following the last letter is used to distinguish between wells in the same $21 / 2$-acre tract.

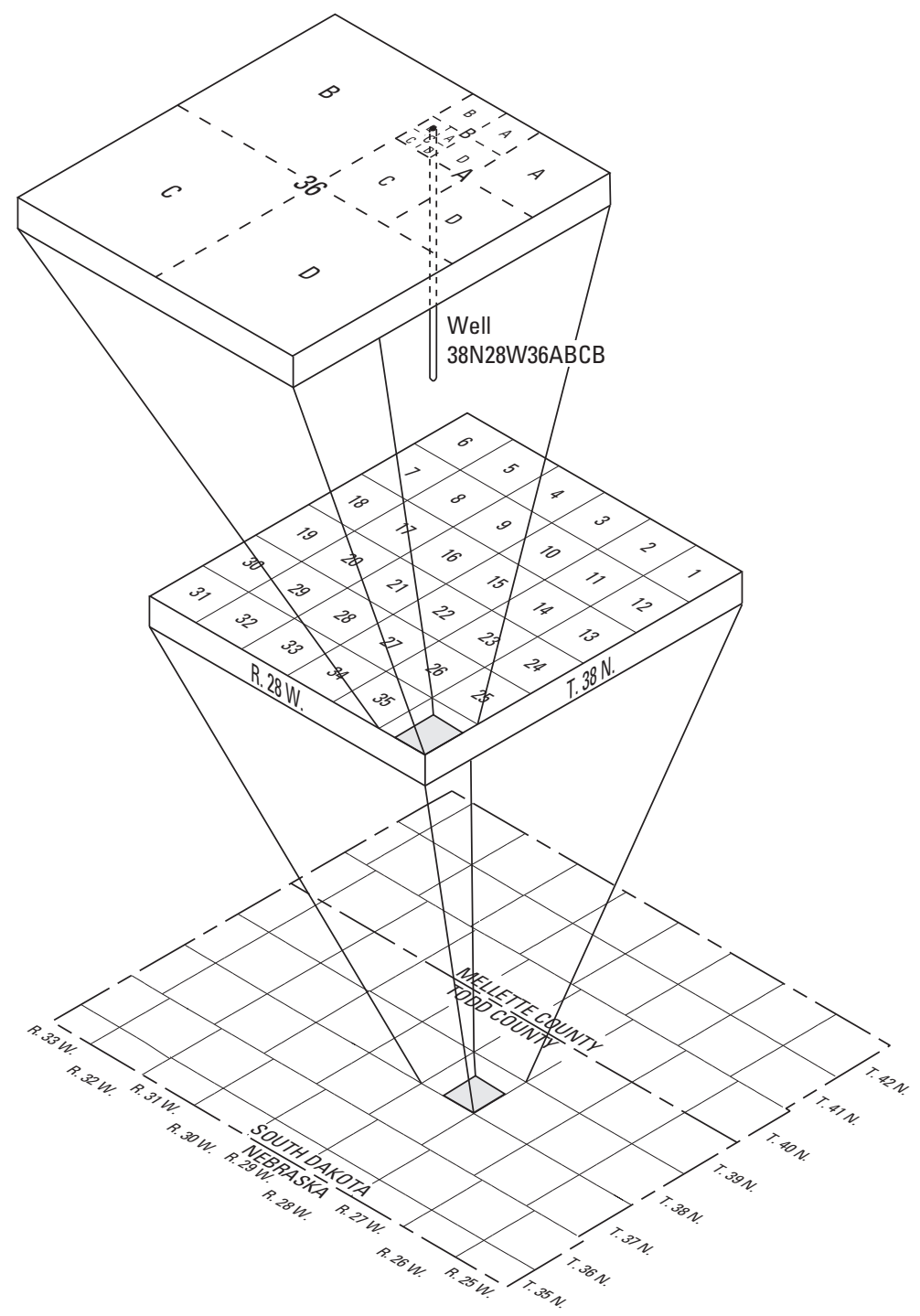





\title{
Simulated Groundwater Flow in the Ogallala and Arikaree Aquifers, Rosebud Indian Reservation Area, South Dakota-Revisions with Data through Water Year 2008 and Simulations of Potential Future Scenarios
}

\author{
By Andrew J. Long and Larry D. Putnam
}

\section{Abstract}

The Ogallala and Arikaree aquifers are important water resources in the Rosebud Indian Reservation area and are used extensively for irrigation, municipal, and domestic water supplies. Drought or increased withdrawals from the Ogallala and Arikaree aquifers in the Rosebud Indian Reservation area have the potential to affect water levels in these aquifers. This report documents revisions and recalibration of a previously published three-dimensional, numerical groundwater-flow model for this area. Data for a 30-year period (water years 1979 through 2008) were used in steady-state and transient numerical simulations of groundwater flow. In the revised model, revisions include (1) extension of the transient calibration period by 10 years, (2) the use of inverse modeling for steady-state calibration, (3) model calibration to base flow for an additional four surface-water drainage basins, (4) improved estimation of transient aquifer recharge, (5) improved delineation of vegetation types, and (6) reduced cell size near large capacity water-supply wells. In addition, potential future scenarios were simulated to assess the potential effects of drought and increased groundwater withdrawals.

The model comprised two layers: the upper layer represented the Ogallala aquifer and the lower layer represented the Arikaree aquifer. The model's grid had 168 rows and 202 columns, most of which were 1,640 feet (500 meters) wide, with narrower rows and columns near large watersupply wells. Recharge to the Ogallala and Arikaree aquifers occurs from precipitation on the outcrop areas. The average recharge rates used for the steady-state simulation were 2.91 and 1.45 inches per year for the Ogallala aquifer and Arikaree aquifer, respectively, for a total rate of 255.4 cubic feet per second $\left(\mathrm{ft}^{3} / \mathrm{s}\right)$. Discharge from the aquifers occurs through evapotranspiration, discharge to streams as base flow and spring flow, and well withdrawals. Discharge rates for the steady-state simulation were $171.3 \mathrm{ft}^{3} / \mathrm{s}$ for evapotranspiration, $74.4 \mathrm{ft}^{3} / \mathrm{s}$ for net outflow to streams and springs, and $11.6 \mathrm{ft}^{3} / \mathrm{s}$ for well withdrawals. Estimated horizontal hydraulic conductivity used for the numerical model ranged from 0.2 to 84.4 feet per day $(\mathrm{ft} / \mathrm{d})$ in the Ogallala aquifer and from 0.1 to $4.3 \mathrm{ft} / \mathrm{d}$ in the Arikaree aquifer. A uniform vertical hydraulic conductivity value of $4.2 \times 10^{-4} \mathrm{ft} / \mathrm{d}$ was estimated for the Ogallala aquifer. Vertical hydraulic conductivity was estimated for five zones in the Arikaree aquifer and ranged from $8.8 \times 10^{-5}$ to $3.7 \mathrm{ft} / \mathrm{d}$. Average rates of recharge, maximum evapotranspiration, and well withdrawals were included in the steady-state simulation, whereas the time-varying rates were included in the transient simulation.

Inverse modeling techniques were used for steady-state model calibration. These methods were designed to estimate parameter values that are, statistically, the most likely set of values to result in the smallest differences between simulated and observed hydraulic heads and base-flow discharges. For the steady-state simulation, the root mean square error for simulated hydraulic heads for all 383 wells was 27.3 feet. Simulated hydraulic heads were within \pm 50 feet of observed values for 93 percent of the wells. The potentiometric surfaces of the two aquifers calculated by the steady-state simulation established initial conditions for the transient simulation. For the transient simulation, the difference between the simulated and observed means for hydrographs was within \pm 40 feet for 98 percent of 44 observation wells.

A sensitivity analysis was used to examine the response of the calibrated steady-state model to changes in model parameters including horizontal and vertical hydraulic conductivity, evapotranspiration, recharge, and riverbed conductance. The model was most sensitive to recharge and maximum evapotranspiration and least sensitive to riverbed and spring conductances.

To simulate a potential future drought scenario, a synthetic recharge record was created, the mean of which was equal to 64 percent of the average estimated recharge rate for the 30 -year calibration period. This synthetic recharge record was used to simulate the last 20 years of the calibration period under drought conditions. Compared with results of the calibrated model, decreases in hydraulic-head values for the drought scenario at the end of the simulation period 
were as much as 39 feet for the Ogallala aquifer. To simulate the effects of potential increases in pumping, well withdrawal rates were increased by 50 percent from those estimated for the 30-year calibration period for the last 20 years of the calibration period. Compared with results of the calibrated model, decreases in hydraulic-head values for the scenario of increased pumping at the end of the simulation period were as much as 13 feet for the Ogallala aquifer.

This numerical model is suitable as a tool to help understand the flow system, to help confirm that previous estimates of aquifer properties were reasonable, and to estimate aquifer properties in areas without data. The model also is useful to help assess the effects of drought and increases in pumping by simulations of these scenarios, the results of which are not precise but may be considered when making water management decisions.

\section{Introduction}

The Ogallala and Arikaree aquifers are included in the High Plains aquifer system that underlies parts of eight States and extends from southern South Dakota to Texas. In 2000, the High Plains aquifer supplied 23 percent of all groundwater used for irrigation, public supply, and industry, and 30 percent of groundwater used for irrigation in the United States (Maupin and Barber, 2005).

The High Plains aquifer underlies about 4,750 square miles $\left(\mathrm{mi}^{2}\right)$ in south-central South Dakota (Gutentag and others, 1984) including most of the Rosebud Indian Reservation. In this area, the Ogallala and Arikaree aquifers are important water resources and are used extensively for irrigation, municipal, and domestic water supplies. From about 1950, when little water use for irrigation occurred, to 2007, groundwater storage declines in the High Plains aquifer nationwide ranged from 0.6 million acre-feet (acre-ft) in South Dakota to 140 million acre-ft in Texas (McGuire, 2009). Continued or increased withdrawals from the Ogallala and Arikaree aquifers in the Rosebud Indian Reservation area have the potential to affect water levels in these aquifers and base-flow discharge to area streams.

The Rosebud Sioux Tribe has identified a need for water-resource tools to evaluate management issues associated with the Ogallala and Arikaree aquifers, such as planning for source-water protection, describing potential effects of contamination, and evaluating effects of drought cycles. A primary tool conceived by the Tribe was a numerical groundwater-flow model of these aquifers for the Rosebud Indian Reservation. Therefore, the Tribe has worked in cooperation with the U.S. Geological Survey (USGS) to develop an initial model (Long and others, 2003) and more recently to revise the model with data through September 30, 2008.

Model revisions include (1) extension of the transient calibration period by 10 years to include data measured through 2008, (2) the use of inverse modeling for steady-state calibration that minimized the squares of the differences between measured and simulated flow metrics, (3) model calibration to base flow for an additional four surface-water drainage basins, (4) improved estimation of transient aquifer recharge using a method that considers antecedent rainfall effects, (5) improved estimation of vegetation types based on satellite imagery for evapotranspiration processes, and (6) reduced cell size near municipal water-supply wells. In addition, potential future scenarios were simulated to assess the effects of potential future hydrologic stresses such as drought conditions and increased groundwater withdrawals.

\section{Purpose and Scope}

The purpose of this report is to describe a conceptual and numerical model developed to simulate groundwater flow in the Ogallala and Arikaree aquifers in the Rosebud Indian Reservation area. The numerical model is a revision of that described in Long and others (2003). Steady-state simulation of average conditions (based on measured data for water years 1979-1998) was used for model calibration. Transient simulations were executed for a 30 -year period of measured data consisting of water years 1979-2008 (October 1, 1978, through September 30, 2008). For convenience of the reader, much of the background material and description of the conceptual model covered in the report by Long and others (2003) is included in this report.

\section{Acknowledgments}

The authors would like to recognize important contributions by the Rosebud Sioux Tribe to the development of the groundwater-flow model described in this report. Development of a calibrated numerical model has resulted from the Tribe's long-term commitment to obtaining hydrologic information, which has been obtained through a series of water-resource investigations that the Tribe has participated in and by data-collection networks operated or supported by the Tribe. Characterization of the Ogallala and Arikaree aquifers was enabled by a substantial program of test-hole drilling and installation of observation wells that was a major component of a water-resource investigation (Carter, 1998) involving the USGS, Rosebud Sioux Tribe, and Geological Survey Program of the South Dakota Department of Environment and Natural Resources. Water-level data from the resulting network of observation wells and from other State and Tribal observation wells have been instrumental for calibration of the numerical model. Tribal support and involvement in collection of streamflow data has been critical for estimation of groundwater discharge rates. The Tribe also was actively involved in study design, conceptualization of the groundwater-flow system, technical evaluation of model performance, and review of this report. 


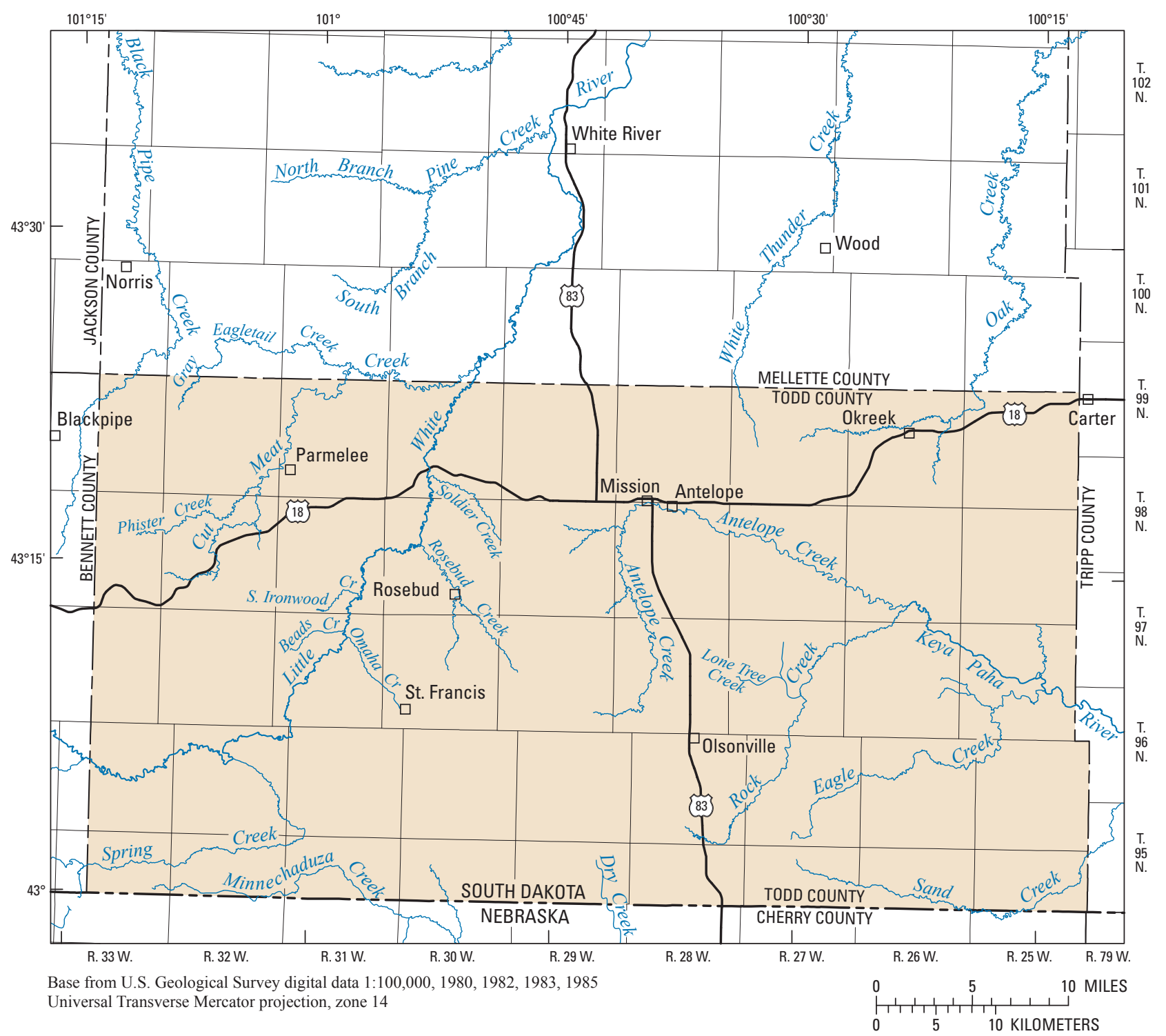

EXPLANATION

Rosebud Indian Reservation

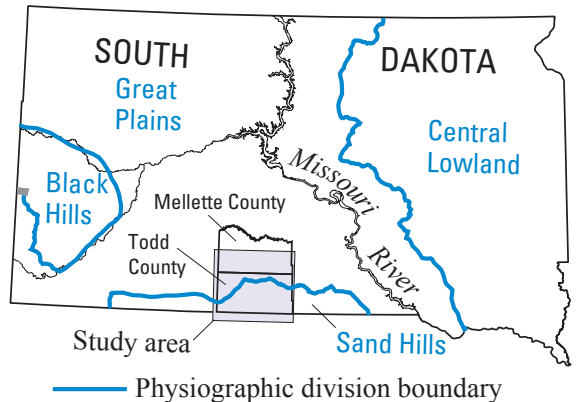

Figure 1. Study area (from Long and others, 2003; physiographic divisions modified from Fenneman, 1946; Flint, 1955).

\section{Description of Study Area}

The study area includes areas within and immediately surrounding the Rosebud Indian Reservation where the Ogallala and Arikaree aquifers are present (fig. 1). The original boundaries of the Rosebud Indian Reservation included all or nearly all of Mellette, Todd, Tripp, and Gregory (east of Tripp) Counties, and a small portion of Lyman County (east of northern Tripp County). Various revisions to the Rosebud Indian Reservation boundary have occurred (Carter, 1998); the boundary was revised to include only Todd County in 1975 (fig. 1). 


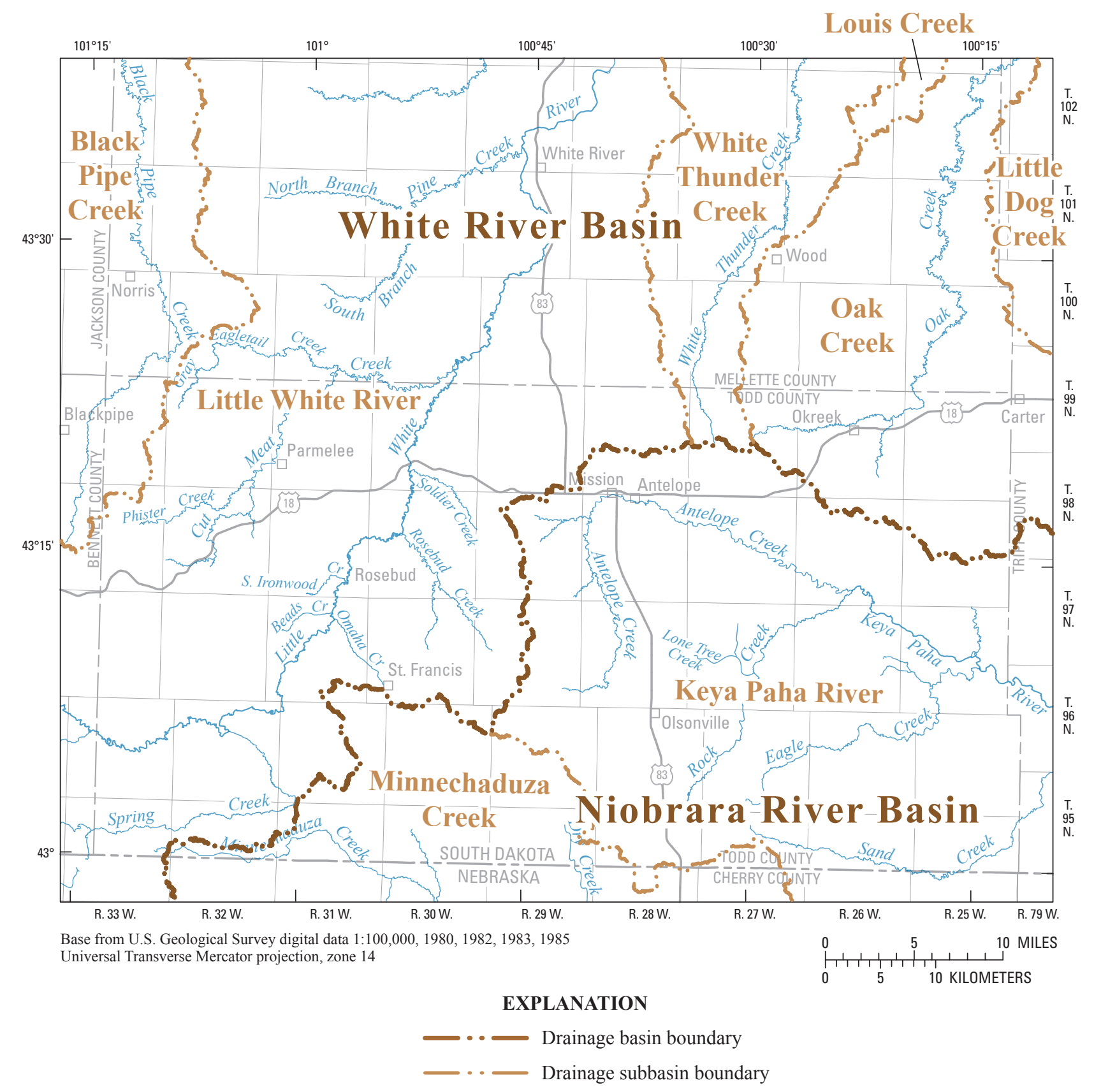

Figure 2. Drainage basins in the study area (from Long and others, 2003).

\section{Physiography and Land Use}

The northern part of the study area is in the Great Plains physiographic province, and the southern part is in the Sand Hills physiographic province (fig. 1). Much of the study area has rolling topography, and numerous deep valleys drain into the White River to the north. Agriculture is the primary land use within the study area. Cattle ranching is the primary agricultural activity with most land used for grazing or hay production. Less than 15 percent of the land is used for crops, which include wheat, sorghum, oats, corn, and alfalfa (Springer, 1974). Most of the crop land is located in south-central Todd County, where extensive irrigation from the Ogallala aquifer occurs. The climate is subhumid with an annual precipitation of about 20 inches (National Climatic Data Center, 2010; Mission station 395620 in Todd County). About 8 percent of the average annual precipitation becomes streamflow; however, this quantity varies because of climatic conditions (Carter, 1998).

\section{Drainage Features and Streamflow}

The major streams that drain the study area (fig. 2) are the Little White River, which flows into the White River in 
northern Mellette County, and the Keya Paha River, which flows into the Niobrara River in Nebraska. Groundwater discharge from the Ogallala and Arikaree aquifers provides base flow to the Little White River, Keya Paha River, and several smaller creeks. These streams generally receive more than one-half of their flow from groundwater discharge, especially during the winter months (Carter, 1998). Direct runoff is the largest component of streamflow for streams with minimal discharge from the Ogallala and Arikaree aquifers. In addition, numerous ephemeral springs occur along the Little White River.

\section{Geology}

The exposed rocks and sediments in the study area range from sedimentary rocks of Cretaceous age to unconsolidated deposits of Quaternary age. Deeper rocks include rocks of Precambrian age, the Ordovician-age Red River and Winnipeg Formations, the Mississippian-age Madison Limestone, and the Permian- and Pennsylvanian-age Minnelusa Formation. Cretaceous-age rocks include the Inyan Kara Group, Skull Creek Shale, Dakota Formation, Graneros Shale, Greenhorn Formation, Carlile Shale, Niobrara Formation, and Pierre Shale. Tertiary-age rocks include the White River Group, Arikaree Formation, and Ogallala Formation. Unconsolidated deposits include terrace, windblown, and alluvial deposits (table 1).

The following descriptions of the Arikaree and Ogallala Formations are from Ellis and others (1971). The Arikaree Formation consists of silicified claystone, silty clays, siltstone, and poorly consolidated sandstone, all of which are a light pinkish tan. The basal 50 to 150 feet (ft) generally is composed of silty and sandy beds that commonly are separated from the upper clayey part by 5 to $10 \mathrm{ft}$ of thin-bedded limestone. Thickness of the Arikaree Formation ranges from 0 to $620 \mathrm{ft}$. The Arikaree Formation forms gently rolling grasscovered hills similar to those formed by the Ogallala Formation, but the banks formed by the Arikaree Formation along streams commonly are steeper.

The Ogallala Formation consists of an upper unit composed of well-cemented, fine- to medium-grained sandstone and a lower unit composed of poorly consolidated clay, silt, and sand. The contact between the units commonly is marked by a bed of silty volcanic ash in the base of the upper unit. This marker bed ranges in thickness from 1 to $4 \mathrm{ft}$. Locally, however, silty limestone or gravel beds may be found at the base of the upper unit. The composition of the beds in the lower unit ranges from silty clay to coarse sand and varies vertically and horizontally. A 5- to 20 -ft thick bed of coarse sand and gravel commonly occurs in the basal part of the lower unit. Thickness of the upper unit ranges from 0 to $40 \mathrm{ft}$ and the lower unit ranges from 0 to $200 \mathrm{ft}$. The upper unit forms the caprock on the isolated buttes and ridges in the southeastern and northwestern parts of Todd County. The lower unit forms the gently rolling grasslands in south-central
Todd County. The upper unit of the Ogallala Formation also is known as the Ash Hollow Formation, and the lower unit also is known as the Valentine Formation.

\section{Hydrologic Setting}

The shallow aquifers in the study area are the alluvial, Ogallala, Arikaree, and White River aquifers. These shallow aquifers consist primarily of unconsolidated sand and gravel or poorly consolidated sandstones and siltstones. The deeper, bedrock aquifers are the Pierre, Dakota Sandstone, Inyan Kara, Minnelusa, and Madison aquifers. In the southern part of the study area, groundwater generally can be obtained from shallow wells (less than $300 \mathrm{ft}$ ) completed in Quaternary-age alluvial deposits or in Tertiary-age deposits (Ogallala Formation, Arikaree Formation, or White River Group). Groundwater is more difficult to obtain in the northern part of the study area where the Tertiary deposits have been eroded resulting in surface exposure of the Pierre Shale (fig. 3).

The Ogallala aquifer comprises the saturated sandstone and silt of the Ogallala Formation. The upper unit of the Ogallala Formation has relatively low permeability, but small seeps occur near its base (Ellis and others, 1971). The lower unit of the Ogallala Formation generally is water bearing; however, the permeability of that unit varies with lithology (Ellis and others, 1971).

The Ogallala aquifer is present throughout most of the southern part of the study area where it underlies $950 \mathrm{mi}^{2}$ in Todd County with an estimated 17 million acre- $\mathrm{ft}$ of water in storage (Carter, 1998). The Ogallala aquifer is not present in the northern part of the study area. The saturated thickness of the Ogallala aquifer in the study area averages $137 \mathrm{ft}$ (Carter, 1998), and the aquifer is fully saturated in some areas. In the study area, the aquifer generally is thickest in the central part of Todd County where withdrawals from the aquifer for irrigation are highest. The Ogallala aquifer is overlain by unconsolidated deposits consisting of alluvium near streams and windblown sand deposits composed of fine- to mediumgrained sand, similar to that of the Ogallala Formation, in the southwestern part of the study area (fig. 3).

The Ogallala aquifer is unconfined except in the southwestern part of the study area where the aquifer is confined by well-cemented layers or concretion beds in the upper part of the formation (Carter, 1998). Where unconfined, the depth to water ranges from 0 to greater than $150 \mathrm{ft}$ below land surface (Carter, 1998). In some areas, the water table in the Ogallala aquifer can be considerably above the altitude of stream bottoms, and numerous seeps occur along hillsides and cliffs in these areas. The Ogallala aquifer has the highest yield potential of all aquifers in the study area with wells yielding from 1 to 1,250 gallons per minute (gal/min; Carter, 1998). Long and others (2003) estimated hydraulic conductivity to be in the range of $0.2-120$ feet per day (ft/d).

The Arikaree aquifer generally comprises the saturated sandstones and siltstones of the Arikaree Formation. The 
Table 1. Generalized stratigraphic column showing geologic units and hydrologic characteristics.

[From Carter, 1998]

\begin{tabular}{|c|c|c|c|c|c|}
\hline Era & System & $\begin{array}{c}\text { Formation or } \\
\text { deposit }\end{array}$ & $\begin{array}{l}\text { Thickness } \\
\text { (feet) }\end{array}$ & Description and origin & Hydrologic characteristics \\
\hline \multirow{6}{*}{ 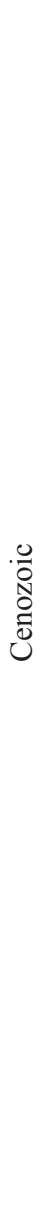 } & \multirow{3}{*}{ 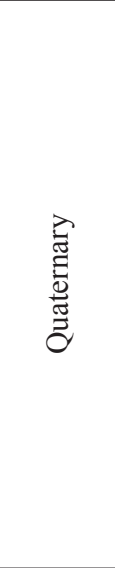 } & Alluvium & $0-35$ & $\begin{array}{l}\text { Brown, varies between clay, silts, fine to coarse sand, } \\
\text { and gravel. Generally sandy along the Little White } \\
\text { River and other streams that flow over deposits of } \\
\text { Tertiary age. Generally clayey with some thin sand } \\
\text { beds along intermittent streams that flow over the } \\
\text { Pierre Shale. Fluvial. }\end{array}$ & $\begin{array}{l}\text { Locally, deposits are moderately permeable along the Little White River } \\
\text { and relatively impermeable along streams that flow over the Pierre } \\
\text { Shale. Yields generally are adequate to supply domestic and stock } \\
\text { wells except along streams that flow over the Pierre Shale. Water is } \\
\text { fresh, low in concentrations of dissolved solids, and soft to moder- } \\
\text { ately hard except in deposits underlain by the Pierre Shale. }\end{array}$ \\
\hline & & $\begin{array}{l}\text { Windblown sand } \\
\text { deposits }\end{array}$ & $0-150$ & $\begin{array}{l}\text { Brown, unconsolidated, very fine to medium grained, } \\
\text { uniform, quartz sand; characterized by dune topog- } \\
\text { raphy and blowouts. Eolian. }\end{array}$ & $\begin{array}{l}\text { Generally very permeable and water bearing; yields are adequate to sup- } \\
\text { ply stock and domestic wells except where deposits are small. }\end{array}$ \\
\hline & & Terrace deposits & $0-105$ & $\begin{array}{l}\text { Brown, silty clay, sand, and gravel. Commonly, the } \\
\text { silty and sandy layers are partly cemented, and the } \\
\text { gravel and sand beds commonly are interbedded } \\
\text { with laminated silty clay. Fluvial. }\end{array}$ & $\begin{array}{l}\text { Generally water bearing in the basal portion of the deposits. Yields are } \\
\text { usually adequate to supply stock and domestic wells. Water is fresh, } \\
\text { low in concentrations of dissolved solids, and soft to moderately hard } \\
\text { except in areas where the water-bearing deposits are underlain by the } \\
\text { Pierre Shale. }\end{array}$ \\
\hline & \multirow{3}{*}{ : } & Ogallala Formation & $0-240$ & $\begin{array}{l}\text { Tan to olive, fine- to medium-grained sandstone with } \\
\text { some silty clay. Upper unit of Ogallala Formation } \\
\text { also is known as the Ash Hollow Formation and the } \\
\text { lower unit as the Valentine Formation. Fluvial. }\end{array}$ & $\begin{array}{l}\text { The upper part of the formation generally has low permeability, but } \\
\text { small seeps occur near its base. The lower part of the formation can } \\
\text { be very permeable and generally is water-bearing; yields are adequate } \\
\text { to supply stock and domestic wells and can supply irrigation wells in } \\
\text { some areas. Water is fresh, low in concentrations of dissolved solids, } \\
\text { and soft to moderately hard. }\end{array}$ \\
\hline & & Arikaree Formation & $0-620$ & $\begin{array}{l}\text { Pinkish tan to red; consists of poorly consolidated, } \\
\text { tuffaceous sandstone, siltstone, shale, and silty clay. } \\
\text { The Rosebud Formation sometimes is differentiated } \\
\text { as a unit within the Arikaree Formation. Basal unit is } \\
\text { composed mostly of silts and sands. Fluvial. }\end{array}$ & $\begin{array}{l}\text { The upper part of the formation generally has low permeability, but can } \\
\text { yield small amounts of water from fractures, joints, and silty layers. } \\
\text { The basal part is moderately permeable and can supply water for } \\
\text { domestic and stock wells. Water is fresh, low in concentrations of dis- } \\
\text { solved solids, and soft to moderately hard. }\end{array}$ \\
\hline & & $\begin{array}{l}\text { White River Group } \\
\text { (undifferentiated) }\end{array}$ & $0-470$ & $\begin{array}{l}\text { Yellow to brown, poorly consolidated siltstone and } \\
\text { claystone with some beds of fine sand. Units of the } \\
\text { White River Group sometimes are differentiated into } \\
\text { the Brule and Chadron Formations. Fluvial. }\end{array}$ & $\begin{array}{l}\text { Permeability varies from low to moderate, depending on the clay } \\
\text { content. Yields are usually adequate to supply water to stock and } \\
\text { domestic wells. Water is slightly saline, moderate in concentrations of } \\
\text { dissolved solids, and hard depending on the proximity of the aquifer } \\
\text { to the Pierre Shale. }\end{array}$ \\
\hline
\end{tabular}


Table 1. Generalized stratigraphic column showing geologic units and hydrologic characteristics.—Continued

[From Carter, 1998]

\begin{tabular}{|c|c|c|c|c|c|}
\hline Era & System & Formation or deposit & $\begin{array}{l}\text { Thickness } \\
\text { (feet) }\end{array}$ & Description and origin & Hydrologic characteristics \\
\hline \multirow{8}{*}{ 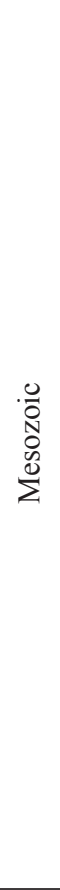 } & \multirow{8}{*}{ 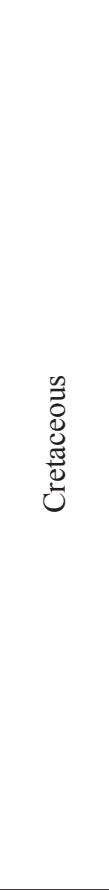 } & Pierre Shale & $600-1,395$ & Bluish-black shale with some layers of bentonite. Marine. & $\begin{array}{l}\text { Most of the formation is relatively impermeable. Can yield } \\
\text { small amounts of water if fractures or sandy zones are pres- } \\
\text { ent. Typically not considered an aquifer. Water is saline, high } \\
\text { in concentrations of dissolved solids, and very hard. }\end{array}$ \\
\hline & & Niobrara Formation & $125-175$ & $\begin{array}{l}\text { Tan to gray, highly calcareous shale. Commonly de- } \\
\text { scribed by drillers as "chalk." Marine. }\end{array}$ & $\begin{array}{l}\text { Water-bearing traits are largely unknown. May yield sufficient } \\
\text { water for some purposes. }\end{array}$ \\
\hline & & Carlile Shale & $300-400$ & Light grayish blue to black, noncalcareous shale. Marine. & Very low permeability. Water-bearing traits are largely unknown. \\
\hline & & Greenhorn Formation & $100-120$ & Tan, bluish, white, or gray calcareous shale. Marine. & Water-bearing traits are largely unknown. \\
\hline & & Graneros Shale & $130-200$ & Dark-gray non-calcareous shale. Marine. & Very low permeability. Water-bearing traits are largely unknown. \\
\hline & & $\begin{array}{l}\text { Dakota Formation } \\
\text { (Dakota Sandstone) }\end{array}$ & $270-340$ & $\begin{array}{l}\text { Interbedded tan to white sandstone and dark-colored } \\
\text { shale. Sandstone is composed of loose to well- } \\
\text { cemented, very fine to coarse quartz sand; cement most } \\
\text { commonly is calcium carbonate. Marine. }\end{array}$ & $\begin{array}{l}\text { Permeable sandstone beds yield moderate quantities of water } \\
\text { under artesian pressure for stock and domestic wells. The } \\
\text { water is highly mineralized and cannot be used for irrigation } \\
\text { purposes. }\end{array}$ \\
\hline & & Skull Creek Shale & $95-150$ & Dark bluish-gray shale. Marine. & Very low permeability. Water-bearing traits are largely unknown. \\
\hline & & $\begin{array}{l}\text { Inyan Kara Group } \\
\quad \text { (undifferentiated) }\end{array}$ & $100-275$ & $\begin{array}{l}\text { White to light-gray or tan sandstone and siltstone; con- } \\
\text { tains beds of gray to black and reddish to buff shale. } \\
\text { The Inyan Kara Group sometimes is divided into the } \\
\text { Fall River and Lakota Formations. Continental to } \\
\text { marginal marine. }\end{array}$ & $\begin{array}{l}\text { Permeable sandstone beds yield moderate quantities of water } \\
\text { under artesian pressure for stock and domestic wells. The } \\
\text { water is highly mineralized and cannot be used for irrigation } \\
\text { purposes. }\end{array}$ \\
\hline \multirow{3}{*}{ 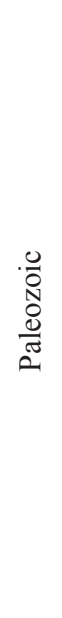 } & 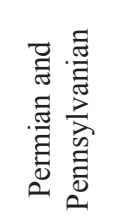 & Minnelusa Formation & $300-530$ & $\begin{array}{l}\text { Consists of interbedded sandstone, siltstone, dolomite, } \\
\text { limestone, anhydrite, and shale. Marine. }\end{array}$ & $\begin{array}{l}\text { Permeable zones can yield adequate water for stock and domes- } \\
\text { tic wells under artesian pressure. Water is lower in dissolved } \\
\text { solids than the Dakota Sandstone and Inyan Kara aquifers. } \\
\text { Can be used for irrigation on crops that are tolerant of salt } \\
\text { with proper salinity management. }\end{array}$ \\
\hline & 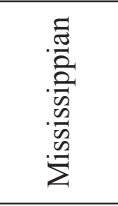 & Madison Formation & $90-240$ & $\begin{array}{l}\text { Light gray to buff, varies from pure limestone to pure do- } \\
\text { lomite with various combinations of the two. Marine. }\end{array}$ & $\begin{array}{l}\text { Permeable zones can yield adequate water for stock and domes- } \\
\text { tic wells under artesian pressure. Water is lower in dissolved } \\
\text { solids than the Dakota Sandstone and Inyan Kara aquifers. } \\
\text { Can be used for irrigation on crops that are tolerant of salt } \\
\text { with proper salinity management. }\end{array}$ \\
\hline & 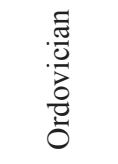 & $\begin{array}{l}\text { Red River and Win- } \\
\text { nipeg Formations } \\
\text { (undifferentiated) }\end{array}$ & $0-170$ & $\begin{array}{l}\text { The Red River Formation mostly consists of dolomite, } \\
\text { and the Winnipeg Formation mostly consists of sand- } \\
\text { stones. Marine. }\end{array}$ & $\begin{array}{l}\text { Water-bearing traits largely unknown. Not used as an aquifer in } \\
\text { vicinity of study area. }\end{array}$ \\
\hline \multicolumn{2}{|c|}{ Precambrian } & & & Granite. & $\begin{array}{l}\text { Water-bearing traits largely unknown. Not used as an aquifer in } \\
\text { vicinity of study area. }\end{array}$ \\
\hline
\end{tabular}




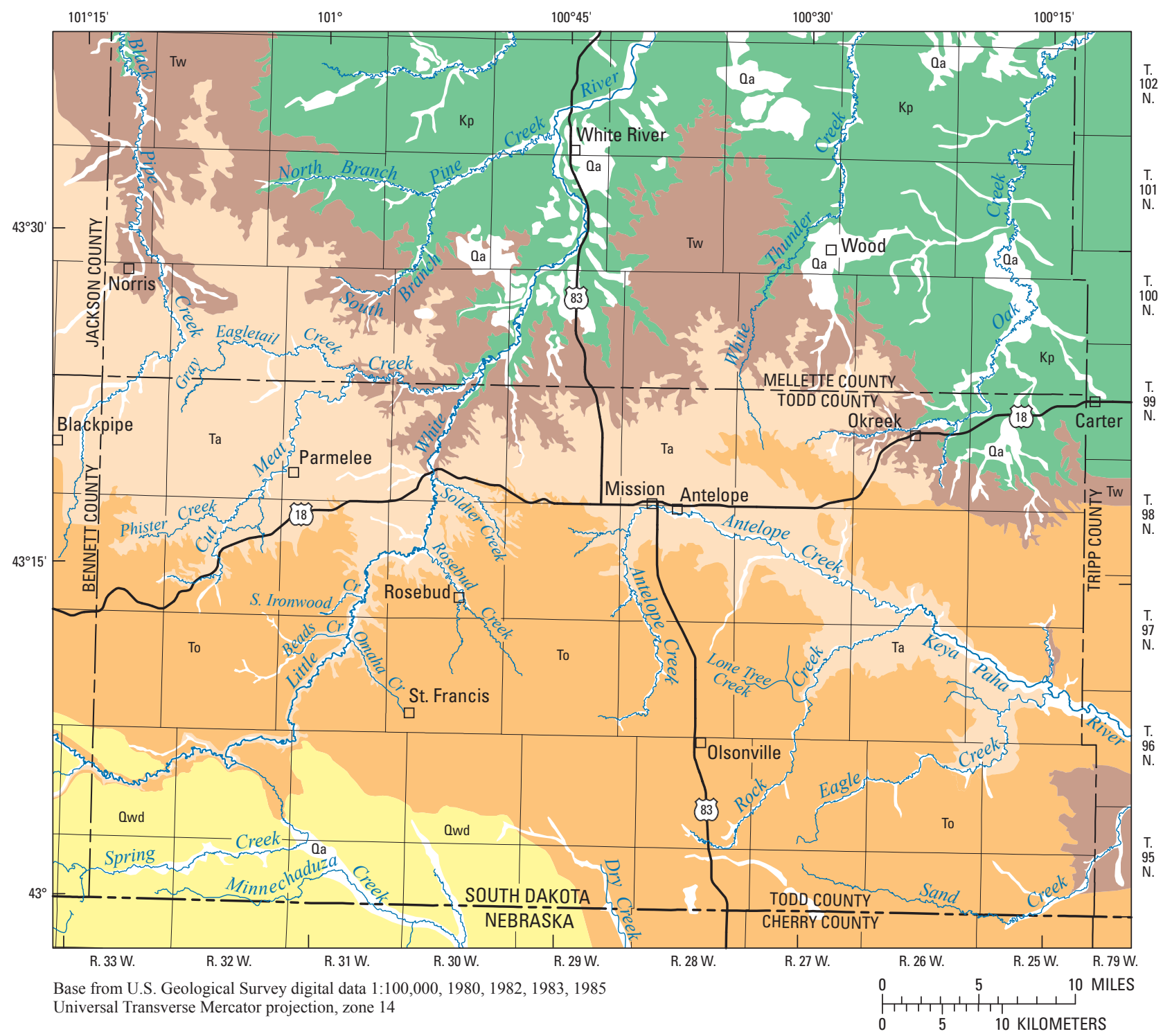

EXPLANATION

Quaternary-age unconsolidated deposits

Qa Alluvium and terrace deposits

awd Windblown sand deposits

Tertiary-age sedimentary deposits

Ogallala Formation

Ta Arikaree Formation

Tw White River Group

Cretaceous-age sedimentary deposits

Pierre Shale

Figure 3. Generalized surficial geology of study area (modified from Ellis and others, 1971).

Ogallala aquifer, where present, overlies the Arikaree aquifer in the study area except in the extreme eastern part of Todd County where the Arikaree Formation does not exist. Beds in the upper clayey part of the Arikaree Formation are composed of relatively low-permeability material, but generally yield water from fractures, joints, and thin silty zones (Ellis and others, 1971). The basal sandy and silty part of the formation is moderately permeable (Ellis and others, 1971). Long and others (2003) estimated hydraulic conductivity to be in the range of $0.1-5.4 \mathrm{ft} / \mathrm{d}$. 
The Arikaree aquifer underlies $1,360 \mathrm{mi}^{2}$ in Todd and Mellette Counties with an estimated 50 million acre- $\mathrm{ft}$ of water in storage (Carter, 1998). The thickness of the Arikaree aquifer ranges from 0 to $618 \mathrm{ft}$, with an average of $290 \mathrm{ft}$ (Carter, 1998). In the study area, the Arikaree aquifer is thickest in southern Todd County. Hydraulic heads in the Arikaree aquifer range from 0 to greater than $150 \mathrm{ft}$ below land surface (Carter, 1998). Like the Ogallala aquifer, the water table in the Arikaree aquifer can be considerably higher in some areas than the altitude of stream bottoms, and numerous seeps occur along hillsides and cliffs in these areas. Well yields range from 1 to $1,005 \mathrm{gal} / \mathrm{min}$ depending on clay content in the aquifer, consolidation of the materials, and well construction; yields generally are less than those from the Ogallala aquifer but are substantially greater than yields from the underlying White River aquifer (Carter, 1998).

\section{Conceptual Model}

The windblown sand deposits overlying the Ogallala aquifer in the southwestern part of the study area have similar hydrogeological properties and are in direct connection with the Ogallala aquifer, and therefore, these units are conceptualized as a single water-bearing unit. The Ogallala and Arikaree aquifers were assumed to be hydraulically connected with the limiting factor of the low permeability of the Arikaree aquifer, which is enhanced by fractures. The White River Group contains an aquifer but was considered an underlying confining unit because of numerous clay lenses that impede vertical groundwater movement.

Recharge to the Ogallala and Arikaree aquifers occurs from precipitation on the outcrop areas, and regional flow enters the study area from the west. Groundwater originating from precipitation recharge moves from areas of higher altitude toward streams that gain flow from the Ogallala and Arikaree aquifers. Discharge by evapotranspiration from the aquifers occurs in areas where the water table is near the land surface, which generally occurs in topographically low areas. Many of the springs that discharge along the banks of the Little White and Keya Paha Rivers probably flow from the Ogallala aquifer because the Arikaree aquifer generally has lower permeability than the Ogallala aquifer. The Arikaree aquifer discharges to springs and seeps on the northern boundary of the aquifer where the surface drainage is towards the north. In addition, discharge from the aquifers occurs through withdrawals from irrigation, public supply, domestic, and stock wells.

For analysis of groundwater flow, data for a 30-year period (water years 1979-2008) were analyzed. Each water year was subdivided into three periods (hereinafter referred to as stress periods) for a total of 90 stress periods for analysis based on the hydrologic characteristics of each period: (1) a fall and winter period, which included the months of October through February; (2) a spring period, which included the months of March through May; and (3) a summer period, which included the months of June through September. The 90 stress periods are numbered 1 through 90 starting with the fall and winter period of water year 1979. During most of the fall and winter period, evapotranspiration is very small because the ground is frozen, plant growth is limited, and precipitation is less than in the spring or summer periods. During the spring period, precipitation is greater than during the fall and winter period, and the evapotranspiration rate is less than during the summer period. During the summer period, evapotranspiration is greatest and irrigation withdrawals are largest.

\section{Groundwater Flow}

Carter (1998) constructed average potentiometric surfaces for the Ogallala and Arikaree aquifers for water years 1979-98 and evaluated hydraulic gradients, flow directions, and aquifer boundaries. Long and others (2003) revised these potentiometric surfaces (figs. 4 and 5). Water levels measured during 1996 for more than 350 wells, primarily domestic, open to the Ogallala and Arikaree aquifers were documented by Carter (1998). Water levels also are available for 44 Tribal and State observation wells open to the Ogallala and Arikaree aquifers for 1979-2008. Of these, 21 are maintained by the Rosebud Sioux Tribe (Rosebud Sioux Tribe, written commun., 2009), and 23 are maintained by the South Dakota Department of the Environment and Natural Resources (Ken Buhler, South Dakota Department of the Environment and Natural Resources, written commun., 2009). During water years 1979-2008, some of these water levels increased, some decreased, and some had little change. Water levels changed as much as 6 and $12 \mathrm{ft}$ for Ogallala and Arikaree aquifers, respectively. There was little, if any, change in general water-level trends from 1999 to 2008 in comparison to the previous 20 years. This is consistent with estimated water-level changes for the High Plains aquifer in South Dakota, where the area-weighted water-level change from 1950 to 2007 was $0 \mathrm{ft}$, the change from 2005-06 was $0.2 \mathrm{ft}$, and the change from 2006-07 was $-0.2 \mathrm{ft}$ (McGuire, 2009). Additional information regarding water-level trends in the study area is in the "Transient Simulation" section of this report.

Water levels generally fluctuated between 1 and $4 \mathrm{ft}$ seasonally. Hydraulic head in the Ogallala aquifer ranged from about $3,000 \mathrm{ft}$ on the western boundary of the study area to about 2,400 ft on the eastern boundary (fig. 4). Hydraulic head in the Arikaree aquifer ranged from about $3,000 \mathrm{ft}$ in the southwestern corner of the study area to about $2,400 \mathrm{ft}$ in parts of the northern and eastern boundaries of the aquifer (fig. 5). Information on wells used to estimate potentiometric surfaces is in Appendix 1.

Groundwater flow in the Ogallala and Arikaree aquifers in the study area generally is to the east or northeast. Locally, groundwater flow is topographically controlled and is towards the Little White and Keya Paha Rivers or smaller streams (figs. 4 and 5). Domestic water use is small in comparison to 


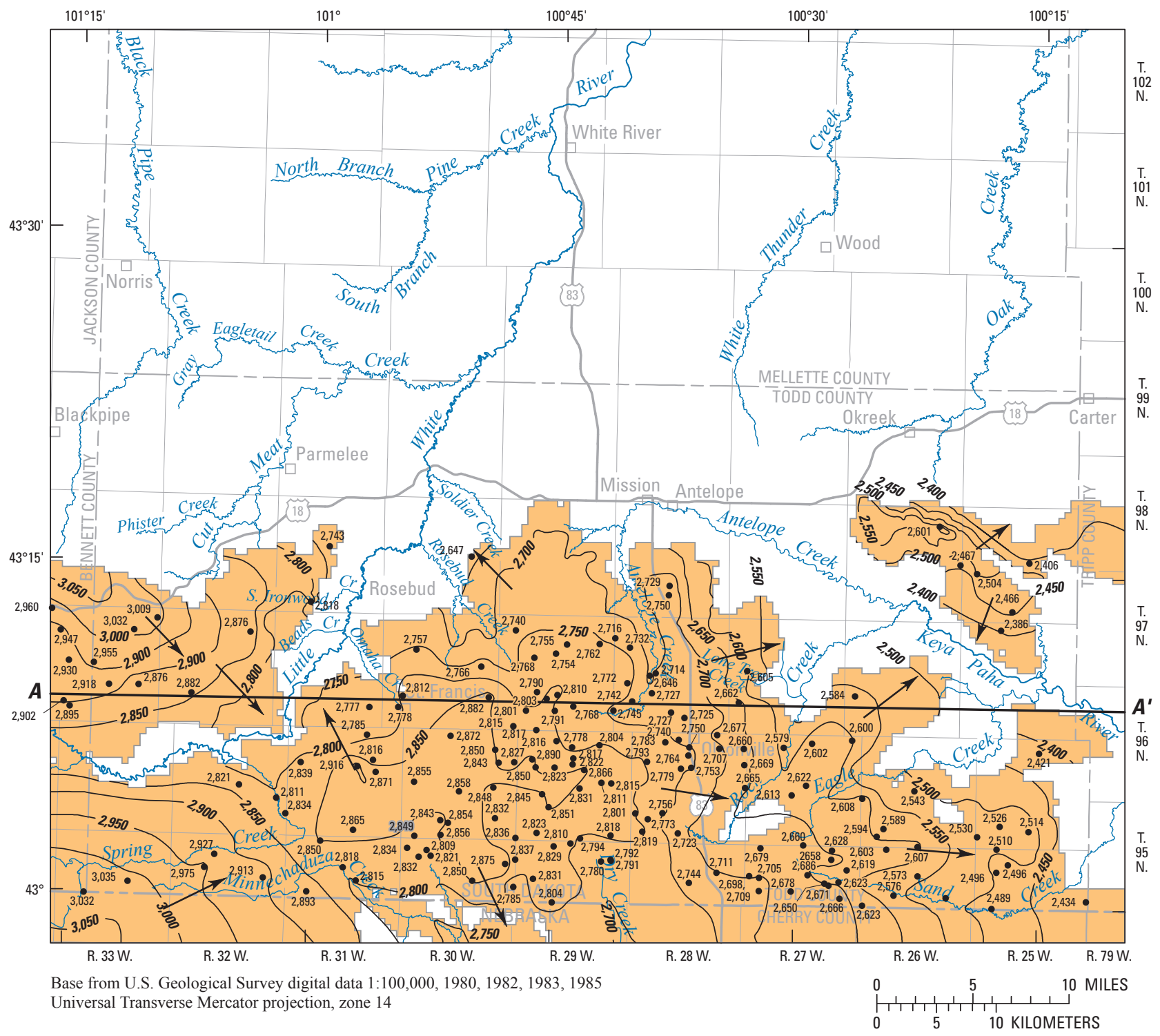

EXPLANATION

Active model cells for Ogallala aquifer

$\underline{A} \quad \boldsymbol{A}^{\prime} \quad$ Trace of geologic section (fig. 6)

- 2,400 - Aquifer potentiometric contour-Shows average altitude at which water level would have stood in tightly cased wells, water years 1979-98. Contour interval is 50 feet. Datum is NGVD of 1929

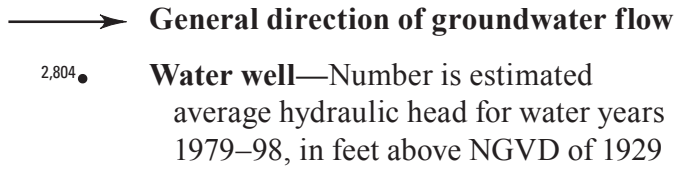

1979-98, in feet above NGVD of 1929

Figure 4. Estimated average potentiometric surface of the Ogallala aquifer (from Long and others, 2003).

irrigation, and municipal water-supply wells have little local effect on groundwater flow. Groundwater flows from recharge areas towards streams and topographically low areas where discharge occurs as base flow to streams or evapotranspiration. The relation between hydraulic heads and topographic features (fig. 6) shows the local influence of streams on the direction of groundwater flow. In particular, the Little White River, which is deeply incised into the Ogallala aquifer and to a lesser extent into the Arikaree aquifer, strongly influences groundwater flow. The Keya Paha River is hydraulically connected to the Arikaree aquifer (fig. 3), and tributary streams gain water from the Ogallala aquifer. A comparison between the surfacedrainage basins (fig. 2) and the potentiometric surfaces (figs. 4 and 5) shows that groundwater divides are related to the surface-drainage basins. 


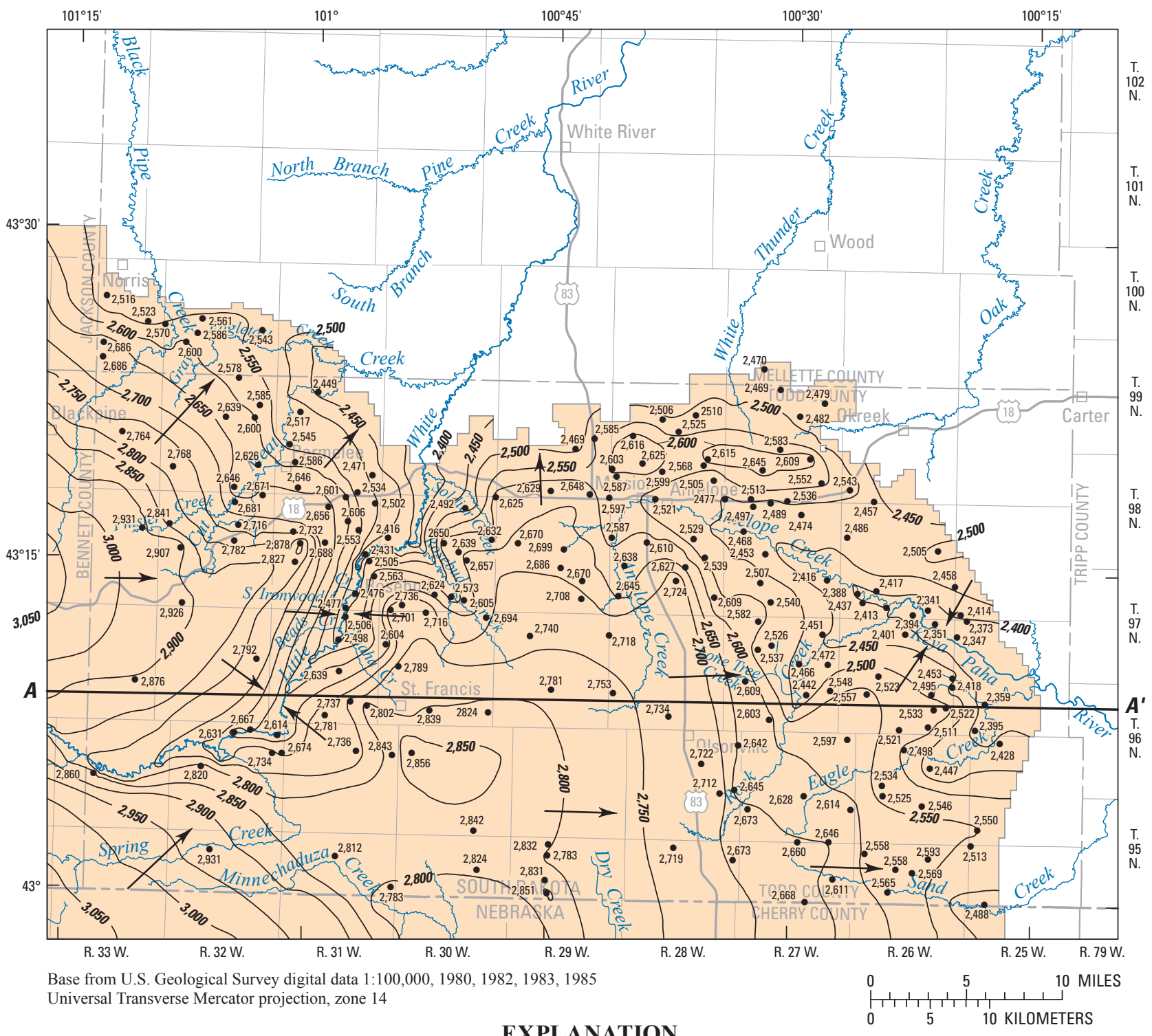

EXPLANATION

Active model cells for Arikaree aquifer

\section{$\underline{A} \quad \boldsymbol{A}^{\prime} \quad$ Trace of geologic section (fig. 6)}

- 2,800 - Potentiometric contour-Shows average altitude at which water level would have stood in tightly cased wells, water years 1979-98. Contour interval is 50 feet. Datum is NGVD of 1929

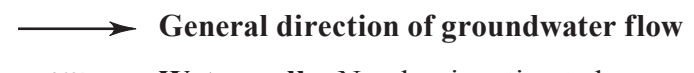

2,804

Water well-Number is estimated average hydraulic head for water years 1979-98, in feet above NGVD of 1929

Figure 5. Estimated average potentiometric surface of the Arikaree aquifer (from Long and others, 2003).

On the basis of previous estimates and model calibration, Long and others (2003) estimated hydraulic conductivity $(K)$ values. For the Ogallala aquifer, horizontal $K$ estimates ranged from 0.2 to $120 \mathrm{ft} / \mathrm{d}$, and the vertical $K$ estimate was $6.6 \times 10^{-4}$ $\mathrm{ft} / \mathrm{d}$. For the Arikaree aquifer, horizontal $K$ estimates ranged from 0.1 to $5.4 \mathrm{ft} / \mathrm{d}$, and vertical $K$ estimates ranged from $8.6 \times 10^{-6}$ to $7.2 \times 10^{-1} \mathrm{ft} / \mathrm{d}$.

\section{Recharge}

Recharge to the Ogallala aquifer occurs from infiltration of precipitation on the outcrop of the Ogallala Formation and the overlying windblown sand deposits in the southeastern part of the study area. Recharge to the Arikaree aquifer occurs from infiltration of precipitation on the outcrop of the Arikaree Formation. 


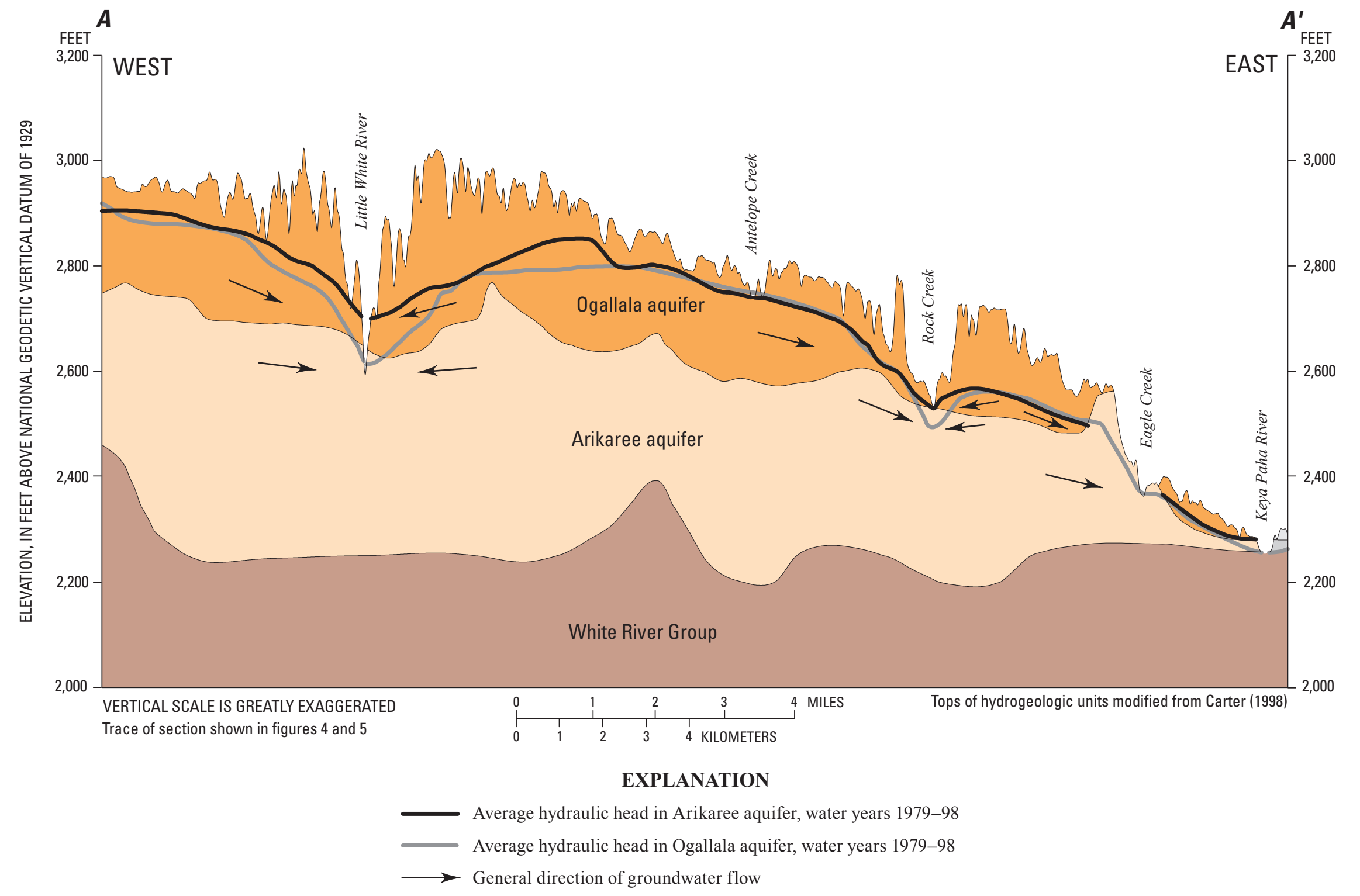

Figure 6. Relation between hydraulic head, hydrogeologic units, and topographic features. 
Previous investigators have estimated recharge for the High Plains aquifer, which includes the Ogallala and Arikaree aquifers. These estimates include 15 percent of precipitation or 2.5 to 3.0 inches per year (in/yr) for the study area (Langbein, 1949), $2.6 \mathrm{in} / \mathrm{yr}$ in the upper Niobrara River Basin (Bradley, 1956), $3.07 \mathrm{in} / \mathrm{yr}$ for the Sand Hills of Nebraska (Rahn and Paul, 1975), and 8 percent of precipitation or 1.3 to $1.8 \mathrm{in} / \mathrm{yr}$ for South Dakota (Kolm and Case, 1983). These estimates primarily pertain to precipitation recharge to the overlying Ogallala aquifer. The lower permeability of the Arikaree aquifer, particularly in the upper part, may prevent that aquifer from accepting as much precipitation recharge as the Ogallala aquifer.

Recharge to the aquifers from infiltrating irrigation water, or irrigation return flow, was considered negligible because total irrigation for the study area was less than 5 percent of estimated recharge in the study area, and irrigation return flow was assumed to be a small fraction of total irrigation. Additional details on irrigation and recharge estimates are in the "Well Withdrawals" and "Model Calibration" sections.

\section{Evapotranspiration}

Evapotranspiration occurs when the water table is at or near the land surface and thus generally occurs in topographically low areas such as river valley bottoms. The water-table altitude influences the evapotranspiration rate. When the water table is at the land surface, evapotranspiration is larger than when the water table is below the land surface. Evapotranspiration is smallest when the water table is below the root zone. Generally, the depth of this root zone is assumed to be about 5 to $10 \mathrm{ft}$ in the study area with deeper root penetration associated with pine and deciduous forests, which are common as much as one-half mile (mi) from the Little White River and its tributaries between Spring Creek and Soldier Creek. Forests also are common near streams along the northern extent of the outcrop of the Arikaree Formation. Other parts of the study area generally are grasslands or agricultural. Land-cover information was obtained from the Multi-Resolution Land Characteristics Consortium (2009) to differentiate forests from grasslands and agricultural areas. To simplify the vegetation zones, small areas less than about $0.7 \mathrm{mi}^{2}$ were removed and included in the surrounding vegetation zones (see "Numerical Model" section).

Maximum evapotranspiration during summer stress periods was estimated as 70 percent of pan evaporation on the basis of the relation between pan evaporation and evapotranspiration described by Farnsworth and others (1982). Pan evaporation rates in the study area were assumed to be similar to those at a National Weather Service climatological data station at Cottonwood (National Climatic Data Center, 2010; station 391972), which is located about $75 \mathrm{mi}$ northwest of the study area. Pan evaporation records were available for the months of June through September for the 30 water years included in the analysis. The estimated maximum evapotranspiration for the 30 summer stress periods (table 2) ranged from 20.4 to 30.7 inches (in.), with a median value of 26.5 in. On the basis of sparse pan evaporation data for spring and late fall, a value for all spring stress periods was estimated as $9 \mathrm{in}$., and a value for all fall/winter stress periods was estimated as $3 \mathrm{in}$. On the basis of these estimates and the assumption that maximum evapotranspiration was 70 percent of pan evaporation, the maximum evapotranspiration was calculated as 6.3 and 2.1 in., respectively, for the spring and fall/winter stress periods.

\section{Discharge to Streams and Springs}

Springs and seeps discharge groundwater to streams in the study area. Long and others (2003) estimated the average groundwater discharge, or base flow, to the Little White and Keya Paha Rivers in the study area for water years 1979-98 as 49 and $23 \mathrm{ft}^{3} / \mathrm{s}$, respectively. These estimates were made

Table 2. Estimated maximum evapotranspiration rate during summer stress periods, water years 1979-2008.

\begin{tabular}{|c|c|c|c|}
\hline $\begin{array}{l}\text { Water } \\
\text { year }\end{array}$ & $\begin{array}{l}\text { Stress } \\
\text { period }\end{array}$ & $\begin{array}{c}\text { Pan evaporation } \\
\text { (inches) }\end{array}$ & $\begin{array}{l}\text { Estimated maximum } \\
\text { June-September } \\
\text { evapotranspiration } \\
\text { (inches) }\end{array}$ \\
\hline 1979 & 3 & 35.4 & 24.8 \\
\hline 1980 & 6 & 41.6 & 29.1 \\
\hline 1981 & 9 & 35.5 & 24.9 \\
\hline 1982 & 12 & 31.4 & 22.0 \\
\hline 1983 & 15 & 40.4 & 28.3 \\
\hline 1984 & 18 & 38.0 & 26.6 \\
\hline 1985 & 21 & 39.7 & 27.8 \\
\hline 1986 & 24 & 29.9 & 20.9 \\
\hline 1987 & 27 & 39.5 & 27.6 \\
\hline 1988 & 30 & 43.8 & 30.7 \\
\hline 1989 & 33 & 42.1 & 29.5 \\
\hline 1990 & 36 & 40.5 & 28.3 \\
\hline 1991 & 39 & 37.8 & 26.5 \\
\hline 1992 & 42 & 30.8 & 21.6 \\
\hline 1993 & 45 & 29.2 & 20.4 \\
\hline 1994 & 48 & 37.4 & 26.2 \\
\hline 1995 & 51 & 36.2 & 25.3 \\
\hline 1996 & 54 & 39.5 & 27.7 \\
\hline 1997 & 57 & 32.1 & 22.5 \\
\hline 1998 & 60 & 31.3 & 21.9 \\
\hline 1999 & 63 & 32.0 & 22.4 \\
\hline 2000 & 66 & 38.9 & 27.2 \\
\hline 2001 & 69 & 35.4 & 24.7 \\
\hline 2002 & 72 & 40.5 & 28.3 \\
\hline 2003 & 75 & 40.5 & 28.3 \\
\hline 2004 & 78 & 36.5 & 25.5 \\
\hline 2005 & 81 & 38.9 & 27.3 \\
\hline 2006 & 84 & 40.2 & 28.1 \\
\hline 2007 & 87 & 40.6 & 28.4 \\
\hline 2008 & 90 & 34.5 & 24.1 \\
\hline
\end{tabular}




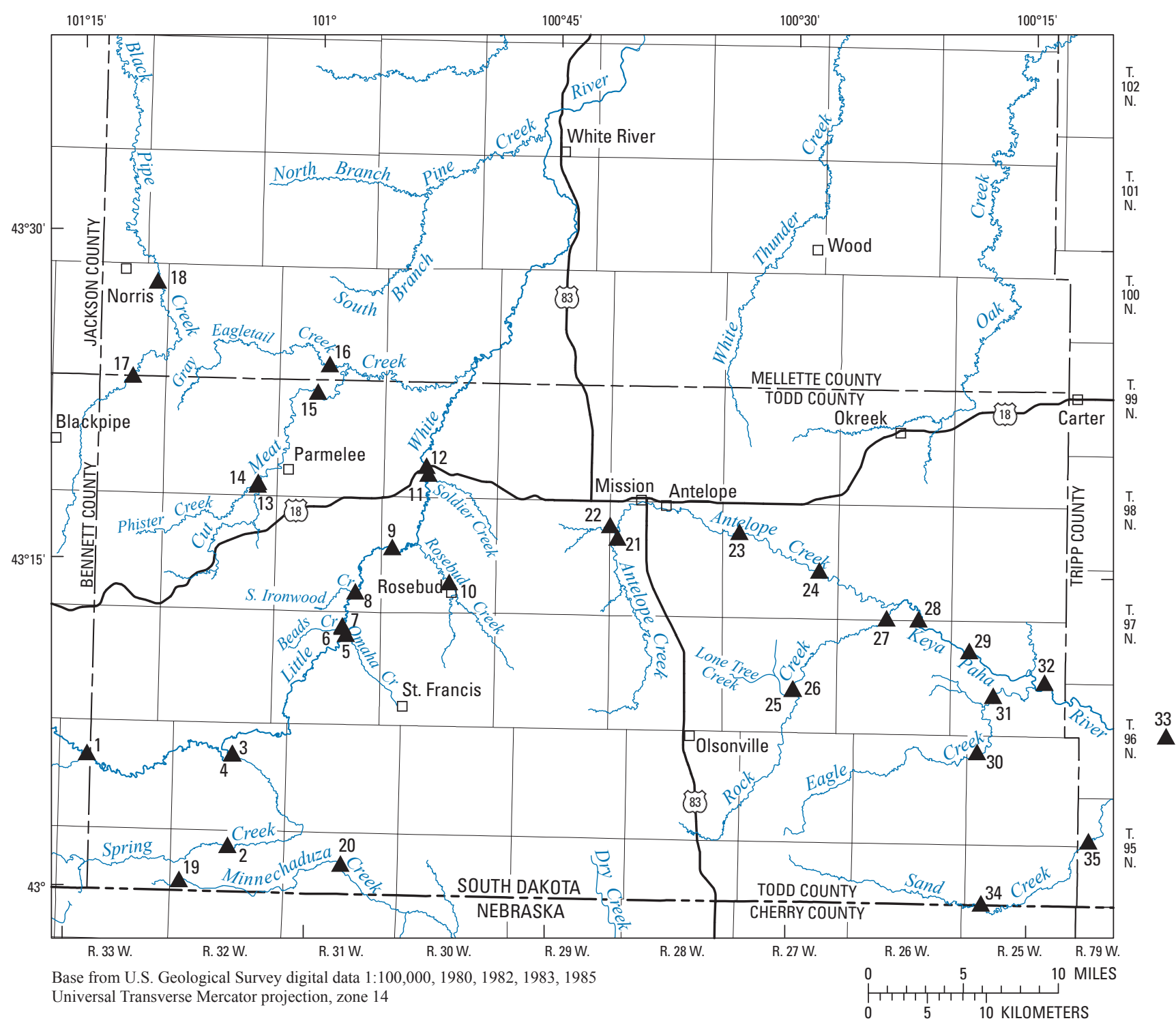

EXPLANATION

${ }^{10}$ Measurement site-Number is map index number in table 3

Figure 7. Streamflow measurement sites for seepage runs during 1999 and 2006.

by applying hydrograph separation methods to continuous streamflow measurements. Additional manual streamflow measurements were used to verify these estimates and to estimate base flow for four other drainage basins - Cut Meat Creek, Black Pipe Creek, Minnechaduza Creek, and Sand Creek (table 3). Four sets of synoptic measurements of streamflow at low-flow conditions during late summer and fall were collected to assess base flow. Streamflow was measured by wading streams with vertical-axis bucket-wheel current meters as described by Rantz and others (1982). Streamflow was measured at 35 sites (fig. 7) twice during 1999 and twice during 2006, with the exception of a few sites that were not measured on all four dates because of limited access (table 3).
These measurements were made during periods when direct runoff was not observed to occur and thus represent approximate base-flow conditions.

Base flow for the Little White River in the study area is approximated by the subtraction of base flow at the furthest upstream site (site 1) from base flow at the furthest downstream site (site 12), and base flow for the Keya Paha River is approximated by base flow at site 33 (fig. 7, table 3).

The average of these base-flow approximations for the four measurements was 54 and $18 \mathrm{ft}^{3} / \mathrm{s}$ for the Little White and Keya Paha Rivers, respectively (table 3 ). These values are similar to estimates of 49 and $23 \mathrm{ft}^{3} / \mathrm{s}$ made by using hydrograph separation techniques on continuous streamflow data 
Table 3. Measured streamflow at selected sites during seepage runs during 1999 and 2006. Estimates of base flow for each drainage basin are shown.

[Shading indicates data used in estimating drainage basin base flow; --, not measured; NA, not applicable]

\begin{tabular}{|c|c|c|c|c|c|c|c|c|}
\hline \multirow[b]{2}{*}{$\begin{array}{l}\text { Map } \\
\text { label } \\
\text { (fig. 7) }\end{array}$} & \multirow[b]{2}{*}{$\begin{array}{c}\text { Site identficiation } \\
\text { number }\end{array}$} & \multirow[b]{2}{*}{ Station name } & \multicolumn{6}{|c|}{ Streamflow, in cubic feet per second } \\
\hline & & & $\begin{array}{c}\text { July 27-29, } \\
\text { 1999a }^{a}\end{array}$ & $\begin{array}{c}\text { Aug. 30- } \\
\text { Sept. 1, } \\
1999^{\mathrm{a}}\end{array}$ & $\begin{array}{l}\text { Aug. 7-9, } \\
2006\end{array}$ & $\begin{array}{c}\text { Oct. } \\
\text { 16-17, } \\
2006\end{array}$ & Average & $\begin{array}{c}\text { Drain- } \\
\text { age basin } \\
\text { base-flow } \\
\text { estimate }\end{array}$ \\
\hline \multicolumn{9}{|c|}{ Little White River drainage basin } \\
\hline 1 & 06449100 & Little White River near Vetal, SD & 72.0 & 44.9 & 20.4 & 33.4 & NA & NA \\
\hline 2 & 430158101045400 & Spring Creek near Cody, NE & 2.1 & -- & -- & -- & NA & NA \\
\hline 3 & 430610101044300 & Spring Creek near Spring Creek, near St. Francis, SD & 9.1 & 4.3 & 3.5 & 3.7 & NA & NA \\
\hline 4 & 430611101044600 & Little White River below Spring Creek, near St. Francis, SD & 117 & 66.1 & 39.9 & 57.9 & NA & NA \\
\hline 5 & 431146100574900 & Omaha Creek near Rosebud, SD & .9 & .8 & 6 & 1.0 & NA & NA \\
\hline 6 & 431205100580200 & Beads Creek near Rosebud, SD & 1.5 & 1.0 & .4 & 1.6 & NA & NA \\
\hline 7 & 431208100580300 & Little White River below Beads Creek & 117 & 75.6 & 50.1 & 71.8 & NA & NA \\
\hline 8 & 431343100571700 & South Fork Ironwood Creek, near Rosebud, SD & 1.8 & 1.6 & 1.3 & 1.8 & NA & NA \\
\hline 9 & 06449300 & Little White River above Rosebud, SD & 119 & 84.9 & 57.0 & 81.4 & NA & NA \\
\hline 10 & 06449400 & Rosebud Creek at Rosebud, SD & 8.0 & 7.8 & 4.6 & 8.0 & NA & NA \\
\hline 11 & 431911100525200 & Soldier Creek near Rosebud, SD & 1.7 & 1.9 & 0 & 1.3 & NA & NA \\
\hline \multirow[t]{2}{*}{12} & 06449500 & Little White River near Rosebud, SD & 140 & 99.3 & 60.7 & 85.3 & NA & NA \\
\hline & & Site 12 minus site 1 & 68.0 & 54.4 & 40.3 & 51.9 & 53.7 & $49^{\mathrm{a}, \mathrm{b}}$ \\
\hline \multicolumn{9}{|c|}{ Cut Meat Creek drainage basin } \\
\hline 13 & 431830101033400 & Phister Creek near Parmelee, SD & .7 & 6 & .1 & .4 & NA & NA \\
\hline 14 & 431837101033200 & Cut Meat Creek below Phister Creek, near Parmelee, SD & 1.1 & .7 & .1 & .5 & NA & NA \\
\hline 15 & 432249100595500 & Cut Meat Creek near Parmelee, SD & 2.4 & 0 & 0 & 0 & 0.6 & NA \\
\hline 16 & 432405100591300 & Gray Eagletail Creek near Parmelee, SD & 2.1 & 2.3 & 0 & 0 & 1.1 & 1.7 \\
\hline \multicolumn{9}{|c|}{ Black Pipe Creek drainage basin } \\
\hline 17 & 432323101113300 & Black Pipe Creek near Black Pipe, SD & 3.9 & 2.8 & .2 & 2.4 & NA & NA \\
\hline 18 & 432743101100900 & Black Pipe Creek near Norris, SD & 3.6 & -- & 0 & .7 & 1.4 & 1.2 \\
\hline \multicolumn{9}{|c|}{ Minnechaduza Creek drainage basin } \\
\hline 19 & 430021101075300 & Minnechaduza Creek near Cody, NE & .1 & -- & -- & -- & NA & NA \\
\hline 20 & 430114100574900 & Minnechaduza Creek near Kilgore, NE & 2.7 & -- & .2 & -- & 1.5 & 3.0 \\
\hline \multicolumn{9}{|c|}{ Keya Paha River drainage basin } \\
\hline 21 & 06463900 & Antelope Creek near Mission, SD & 2.0 & 3.2 & 0 & 2.0 & NA & NA \\
\hline 22 & 431700100412500 & Antelope Creek tributary above Mission, SD & .5 & 6 & 0 & .2 & NA & NA \\
\hline 23 & 431648100331800 & Antelope Creek below Antelope Lake near Mission, SD & 4.3 & 1.3 & .1 & .2 & NA & NA \\
\hline
\end{tabular}


Table 3. Measured streamflow at selected sites during seepage runs during 1999 and 2006. Estimates of base flow for each drainage basin are shown.—Continued

[Shading indicates data used in estimating drainage basin base flow; --, not measured; NA, not applicable]

\begin{tabular}{|c|c|c|c|c|c|c|c|c|}
\hline \multirow[b]{2}{*}{$\begin{array}{l}\text { Map } \\
\text { label } \\
\text { (fig. 7) }\end{array}$} & \multirow[b]{2}{*}{$\begin{array}{l}\text { Site identficiation } \\
\text { number }\end{array}$} & \multirow[b]{2}{*}{ Station name } & \multicolumn{6}{|c|}{ Streamflow, in cubic feet per second } \\
\hline & & & $\begin{array}{l}\text { July 27-29, } \\
1999^{\text {a }}\end{array}$ & $\begin{array}{c}\text { Aug. 30- } \\
\text { Sept. 1, } \\
1999^{a}\end{array}$ & $\begin{array}{l}\text { Aug. 7-9, } \\
2006\end{array}$ & $\begin{array}{c}\text { 0ct. } \\
\text { 16-17, } \\
2006\end{array}$ & Average & $\begin{array}{c}\text { Drain- } \\
\text { age basin } \\
\text { base-flow } \\
\text { estimate }\end{array}$ \\
\hline \multicolumn{9}{|c|}{ Keya Paha River drainage basin—Continued } \\
\hline 24 & 431506100281600 & Antelope Creek above Keya Paha River near Mission, SD & 6.1 & 1.7 & 2 & .6 & NA & NA \\
\hline 25 & 430940100294800 & Lone Tree Creek near Olsonville, SD & .7 & 6 & .4 & .4 & NA & NA \\
\hline 26 & 430940100294600 & Rock Creek below Lone Tree Creek, near Olsonville, SD & 5.2 & 4.4 & 2.9 & 3.3 & NA & NA \\
\hline 27 & 431258100240000 & Rock Creek near Mission, SD & 9.4 & 8.6 & 4.1 & 5.9 & NA & NA \\
\hline 28 & 431257100220000 & Keya Paha River below Rock Creek near Mission, SD & 19.3 & 14.1 & 4.7 & 8.6 & NA & NA \\
\hline 29 & 431132100184700 & Keya Paha River above Eagle Creek near Mission, SD & 19.8 & 15.4 & 5.2 & 8.2 & NA & NA \\
\hline 30 & 430645100185200 & Eagle Creek near Olsonville, SD & .2 & 4 & 0 & -- & NA & NA \\
\hline 31 & 430930100171500 & Eagle Creek near Keyapaha, SD & 1.6 & 2.2 & 1.0 & 1.3 & NA & NA \\
\hline 32 & 431008100140300 & Keya Paha River below Eagle Creek, SD & 22.0 & 15.6 & 7.0 & 9.4 & NA & NA \\
\hline 33 & 06464100 & Keya Paha River near Keyapaha, SD & 26.5 & 22.4 & 9.6 & 11.5 & 17.5 & $23.0^{\mathrm{a}}$ \\
\hline \multicolumn{9}{|c|}{$\begin{array}{l}\text { Sand Creek drainage basin } \\
\end{array}$} \\
\hline 34 & 425959100174900 & Sand Creek near Valentine, NE & -- & -- & -- & -- & NA & NA \\
\hline 35 & 430254100111000 & Sand Creek near Keya Paha, SD & 4.4 & 4.5 & 2.6 & 4.0 & 3.9 & 3.9 \\
\hline
\end{tabular}

From Long and others (2003).

${ }^{b}$ Estimated for drainage area within the study area only. 
by Long and others (2003), which indicates that the additional manual measurements could be used to approximate base flow for the four smaller drainage basins in the study area. Therefore, the average streamflow measurements for sites 15 , $16,18,20$, and 35 were used to estimate base flow for the Cut Meat, Black Pipe, Minnechaduza, and Sand Creek drainage basins (fig. 7, table 3). The Black Pipe Creek drainage basin is partly outside of the study area, and the base-flow estimate was reduced accordingly from 1.4 to $1.2 \mathrm{ft}^{3} / \mathrm{s}$ based on the proportion of the area outside of the study area. Site 20 on Minnechaduza Creek is about midway between the stream's headwaters and the model boundary, and to account for unmeasured flow downstream from site 20, the average flow of $1.5 \mathrm{ft}^{3} / \mathrm{s}$ at site 20 was doubled $\left(3.0 \mathrm{ft}^{3} / \mathrm{s}\right)$ and used as the base-flow estimate for the drainage basin. The base-flow estimate of $1.7 \mathrm{ft}^{3} / \mathrm{s}$ for the Cut Meat drainage basin is the sum of the average flows for sites 15 and 16. The base-flow estimate of $3.9 \mathrm{ft}^{3} / \mathrm{s}$ for the Sand Creek drainage basin is the average flow at site 35 . The four smaller drainage basins were estimated to have a total average base flow of $9.8 \mathrm{ft}^{3} / \mathrm{s}$. These estimates are inclusive of spring flow along streambanks. For the Little White and Keya Paha Rivers, the original base-flow estimates of 49 and $23 \mathrm{ft}^{3} / \mathrm{s}$ from Long and others (2003) based on continuous streamflow data were used (table 3 ). Estimated base flow for these two rivers is about 88 percent of the total estimated base flow.

Springs are located along the northern contact of the Arikaree Formation with the underlying White River Group and discharge from the Arikaree aquifer into streams flowing to the north. Spring discharge probably takes place near this contact because of the very low permeability of the White River Group, which causes northerly flowing groundwater to emerge as springflow.

\section{Well Withdrawals}

Well withdrawals in the study area occur primarily for irrigation but also for public supply, domestic use, and stock use. Irrigation withdrawals from the Ogallala aquifer are especially important in Todd County and mainly occur east of St. Francis (fig. 8), where the saturated thickness of the Ogallala aquifer is greatest. The acres of irrigated land in Todd County from 1985 to 2005 ranged from 10,000 to 11,000 acres (U.S. Geological Survey, 2009). Irrigation withdrawals are variable because they are affected by numerous factors, such as climatic conditions, commodity prices, and energy costs. Most of the wells used for irrigation in the study area were constructed in the 1970s.

Water-use data for irrigation and public supply are compiled every 5 years as part of the USGS National Water-Use Information Program in cooperation with local, State, and Federal agencies and is aggregated by counties for each State (U.S. Geological Survey, 2009). Data on groundwater withdrawals from the Ogallala and Arikaree aquifers in the study area were compiled from the USGS Site-Specific
Water-Use Data System (SWUDS) for the period of available record (1981-2005). The SWUDS database includes water use reported by operators under specific water-use permits. The reported use for a permit can include more than one well or center-pivot irrigation system (table 4).

Groundwater withdrawals for 1979 and 1980 were estimated as the average withdrawals for the period 1981-85 and proportioned to each well according to the estimated withdrawals for 1981. Groundwater withdrawals for 2006-08 were estimated as being equal to withdrawals for 2005 . The

Table 4. Estimated groundwater withdrawals for irrigation and public supply in the study area, 1979-2008.

\begin{tabular}{|c|c|c|c|c|}
\hline \multirow{2}{*}{ Year } & \multirow{2}{*}{$\begin{array}{c}\text { Acre-feet } \\
\text { Total }\end{array}$} & \multicolumn{3}{|c|}{ Cubic feet per second ${ }^{a}$} \\
\hline & & $\begin{array}{c}\text { Ogallala } \\
\text { aquifer }\end{array}$ & $\begin{array}{c}\text { Arikaree } \\
\text { aquifer }\end{array}$ & Total \\
\hline 1979 & 6,796 & 28.1 & 0 & 28.1 \\
\hline 1980 & 6,796 & 28.1 & 0 & 28.1 \\
\hline 1981 & 6,852 & 28.3 & 0 & 28.3 \\
\hline 1982 & 7,054 & 29.2 & 0 & 29.2 \\
\hline 1983 & 5,504 & 22.7 & 0 & 22.7 \\
\hline 1984 & 7,751 & 32.0 & 0.05 & 32.0 \\
\hline 1985 & 6,818 & 28.2 & 0 & 28.2 \\
\hline 1986 & 7,481 & 30.7 & .23 & 30.9 \\
\hline 1987 & 5,437 & 22.2 & .23 & 22.5 \\
\hline 1988 & 7,054 & 29.2 & 0 & 29.2 \\
\hline 1989 & 14,524 & 59.5 & .56 & 60.0 \\
\hline 1990 & 10,020 & 41.1 & .28 & 41.4 \\
\hline 1991 & 6,234 & 25.8 & 0 & 25.8 \\
\hline 1992 & 5,178 & 21.4 & 0 & 21.4 \\
\hline 1993 & 5,886 & 24.0 & .28 & 24.3 \\
\hline 1994 & 8,256 & 33.8 & .28 & 34.1 \\
\hline 1995 & 7,088 & 29.2 & .09 & 29.3 \\
\hline 1996 & 11,862 & 49.0 & .00 & 49.0 \\
\hline 1997 & 10,053 & 41.4 & .14 & 41.5 \\
\hline 1998 & 6,459 & 26.5 & .19 & 26.7 \\
\hline 1999 & 6,470 & 26.6 & .19 & 26.7 \\
\hline 2000 & 7,593 & 31.1 & .28 & 31.4 \\
\hline 2001 & 9,267 & 38.2 & .14 & 38.3 \\
\hline 2002 & 13,255 & 54.4 & .37 & 54.8 \\
\hline 2003 & 12,761 & 52.5 & .23 & 52.7 \\
\hline 2004 & 12,783 & 52.5 & .37 & 52.8 \\
\hline 2005 & 10,772 & 44.2 & .28 & 44.5 \\
\hline 2006 & 10,772 & 44.2 & .28 & 44.5 \\
\hline 2007 & 10,772 & 44.2 & .28 & 44.5 \\
\hline 2008 & 10,772 & 44.2 & .28 & 44.5 \\
\hline Average & 8,611 & 35.4 & .17 & 35.6 \\
\hline
\end{tabular}

${ }^{a}$ Withdrawal rate based on a 4-month season (June-September). 
estimated groundwater withdrawal for the study area by year ranged from about 5,200 to 14,500 acre-ft and averaged 8,611 acre-ft (table 4), or $35.6 \mathrm{ft}^{3} / \mathrm{s}$ over a 4 -month period. The largest estimated irrigation use during the analysis period was in 1989 when precipitation was about 4 in. below normal.

\section{Numerical Model}

The numerical flow model of the Ogallala and Arikaree aquifers described in this report is a revision of that described by Long and others (2003), which was an analysis that included water years 1979-98. The revised model includes water years 1979-2008 for transient simulation and was discretized into 90 seasonal stress periods, or three stress periods per year. Future scenarios of potential drought and increased pumping were simulated for a 20 -year period with the calibrated model. Other revisions are listed in table 5 and described in more detail in subsequent sections.

\section{Model Design}

MODFLOW-2000 (Harbaugh and others, 2000), which is a numerical, three-dimensional, finite-difference groundwater model, was used to simulate flow in the aquifers. Details of the MODFLOW-2000 packages that were included in the model were described by McDonald and Harbaugh (1988) and Harbaugh and others (2000). These packages included Layer-Property Flow, River, Recharge, Well, Drain, and Evapotranspiration. Average rates of recharge, maximum evapotranspiration, and well withdrawals were included in the steady-state simulation, and time-varying rates were included in the transient simulation. Model parameters estimated by calibration were horizontal and vertical hydraulic conductivity $(K)$, recharge and evapotranspiration rates, and the vertical hydraulic conductances of riverbeds and springs.

\section{Grid and Boundary Conditions}

The model had two layers: the upper layer represented the Ogallala aquifer and surficial Quaternary-age deposits, and the lower layer represented the Arikaree aquifer. The model's grid had 168 rows oriented east-west and 202 columns oriented north-south. Most of the rows and columns were $1,640 \mathrm{ft}(500$ meters $(\mathrm{m}))$ wide, except that smaller rows and columns were used in areas where large water-supply wells are located because of potentially steep hydraulic gradient in these areas. These rows and columns were $984 \mathrm{ft}(300 \mathrm{~m})$ wide (fig. 9). The height of each cell is equal to the estimated formation thickness, which was determined on the basis of structure-contour maps of the Arikaree Formation and White River Group (Carter, 1998) and land-surface elevation data at a 30-m grid resolution (National Elevation Dataset, 2006). These elevation data were used to represent the top of layer 1, where the Ogallala Formation and overlying windblown deposits are exposed to the land surface, and the top of layer 2, where the Arikaree Formation is exposed. The altitude of the top of the Arikaree Formation, where buried, represented the bottom of layer 1 and top of layer 2. The altitude of the top of the White River Group represented the bottom of layer 2.

Both layers were simulated so that cells were convertible between confined and unconfined conditions. Although the top of layer 1 is the land surface, there is no option in MODFLOW to simulate a layer as strictly unconfined. If hydraulic head in a convertible cell exceeds the top of layer 1, the cell will convert to confined (McDonald and Harbaugh, 1988). This occurs where discharge to simulated streams and spring occurs, which prevents pressure from building in these cells and allows outflow to occur. Cells of constant hydraulic head were used on the western model boundary and the western part of the southern boundary for both layers and also in the southeastern corner for layer 1 (figs. 9 and 10). Other boundaries were designated as no-flow boundaries, which included the edges of the aquifers or where study area boundaries were approximately parallel to the estimated groundwater-flow direction.

Table 5. Revisions to the model described by Long and others (2003).

\begin{tabular}{|c|c|c|}
\hline Category & 2003 model $^{\mathrm{a}}$ & Revision in 2010 model \\
\hline Simulated period, in water years & $1979-1998$ & 1979-2008. \\
\hline Calibration method & Trial-and-error & Inverse modeling. \\
\hline Base-flow calibration & Two drainage basins & Six drainage basins. \\
\hline Recharge estimate & $\begin{array}{l}\text { Percentage of precipitation as a } \\
\text { constant }\end{array}$ & Percentage of recharge is variable. \\
\hline Delineation of vegetation types & Topographic maps & Satellite imagery. \\
\hline Model cell discretization & $\begin{array}{l}\text { Uniform cell size ( } 1,640 \text { feet } \\
\text { each side) }\end{array}$ & $\begin{array}{l}\text { Variable cell size with smallest cells } \\
\text { near municipal production wells } \\
\text { (984 to } 1,640 \text { feet each side). }\end{array}$ \\
\hline
\end{tabular}

${ }^{\mathrm{a}}$ Long and others (2003). 


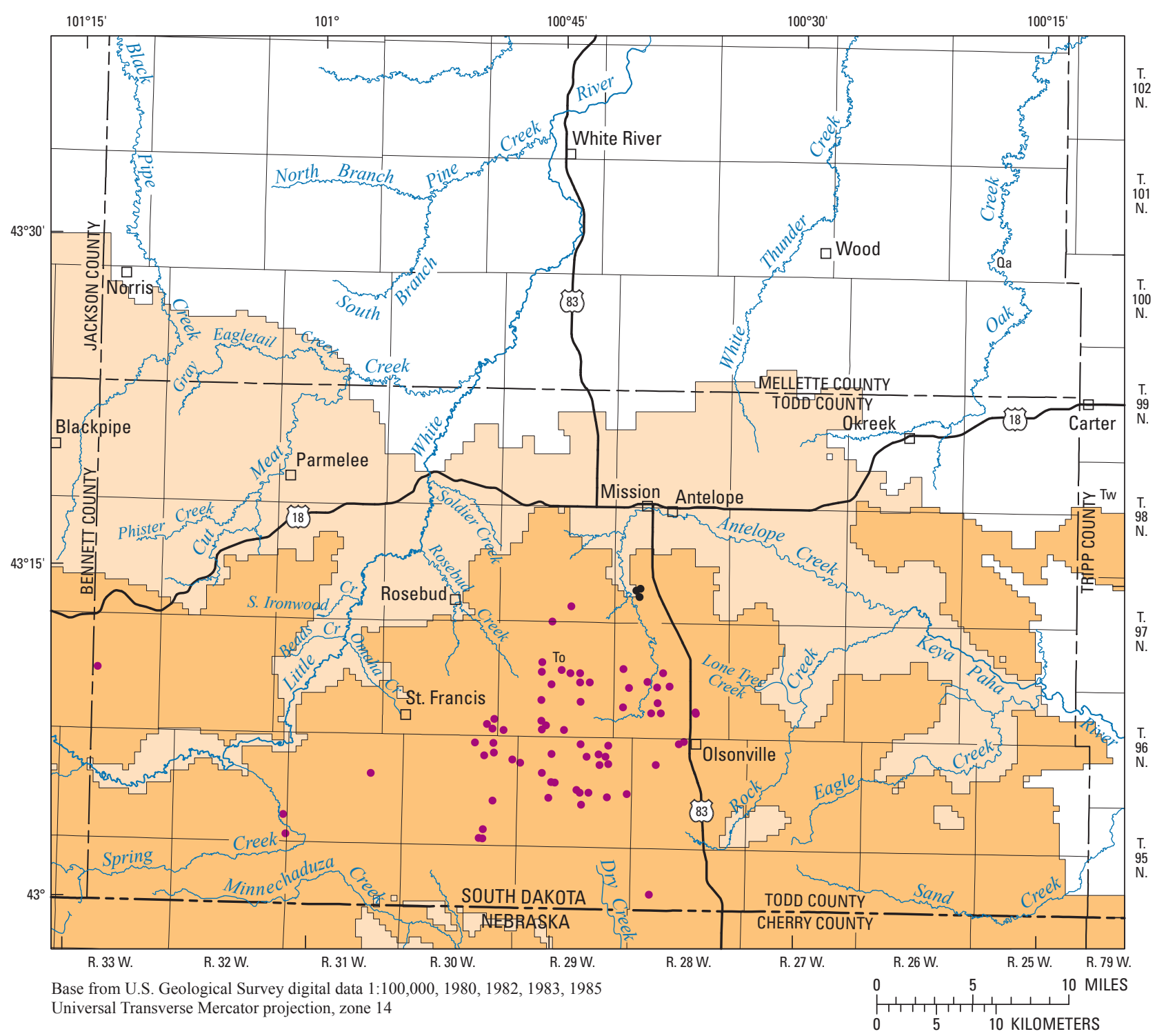

EXPLANATION

Ogallala aquifer recharge area

Arikaree aquifer recharge area
- Water-supply well in Ogallala aquifer

- Water-supply well in Arikaree aquifer

Figure 8. Recharge areas and locations of water-supply wells.

\section{Hydraulic Conductivity}

Zones of constant $K$ were delineated by considering potential structural features, and specific capacities of wells (figs. 11-13). Five major zones for horizontal and vertical $K$ were separated along stream reaches because of the possibility of structural control of streams. Subareas within these zones in the Ogallala aquifer partly were delineated in accordance with spatial variations of specific capacity of wells (fig. 11), especially high specific capacities in the central part of the model area between the Little White and Keya Paha Rivers (Long and others, 2003). Subareas were further delineated as needed for model calibration purposes as described in the
"Model Calibration" section. Parameter estimation for these zones by inverse modeling resulted in horizontal $K$ values ranging from about 0.2 to $84.4 \mathrm{ft} / \mathrm{d}$ for the Ogallala aquifer and about 0.1 to $4.3 \mathrm{ft} / \mathrm{d}$ for the Arikaree aquifer (figs. 11 and 12). Zones of large horizontal $K$ were assigned along the Little White and Keya Paha Rivers in layer 2 (fig. 12) to allow for a substantial groundwater discharge that occurs to these streams. Higher horizontal $K$ may be the result of near-surface weathering, which probably extends below the water table in these topographically low areas. In addition, if the locations of these streams are affected by fractures or faults, higher $K$ values could result. The process of delineating hydraulic conductivity zones is further described in the "Model Calibration" section. 


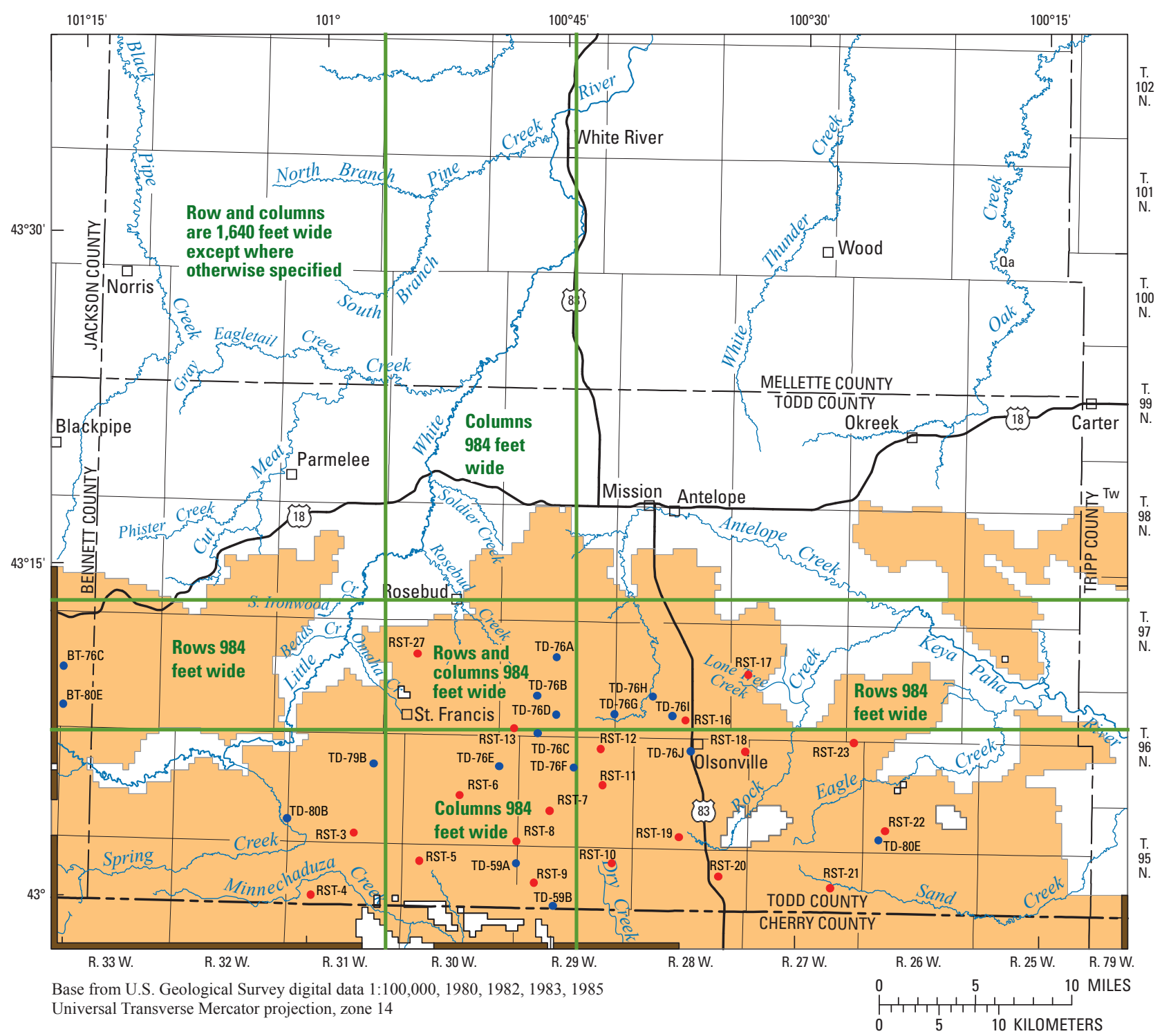

\section{EXPLANATION}

$\square$ Active cells
$\square$ Inactive cells
$\square$ Constant-head cells
RST-10. Tribal observation well completed in Ogallala aquifer. Label is well identifier (table 7)
TD-59A State observation well completed in Ogallala aquifer. Label is well identifier (table 8)

Figure 9. Cell types in the Ogallala aquifer (layer 1), observation wells completed in the Ogallala aquifer, and row and column widths for the Ogallala and Arikaree aquifers.

MODFLOW-2000 calculates vertical $K$ between adjacent layers as the harmonic mean of vertical $K$ for the two layers. The Arikaree aquifer was delineated into five vertical $K$ zones, but because of the harmonic mean calculation, it was not necessary to delineate the Ogallala aquifer into zones to produce unique vertical $K$ values between the two layers. A constant value of $4.2 \times 10^{-4} \mathrm{ft} / \mathrm{d}$ was estimated for the Ogallala aquifer and ranged from $8.8 \times 10^{-5}$ to $3.7 \mathrm{ft} / \mathrm{d}$ for the Arikaree aquifer (fig. 13).

\section{Recharge}

Recharge accounted for by the Recharge Package in MODFLOW-2000 (McDonald and Harbaugh, 1988) is the amount of infiltrating precipitation that surpasses the root zone and reaches the water table. Recharge rates for the steady-state simulation were estimated from model calibration (see "Model Calibration" section) and were consistent with previously published values. Recharge was $2.91 \mathrm{in} / \mathrm{yr}$ for the Ogallala aquifer (about 15 percent of average precipitation for 


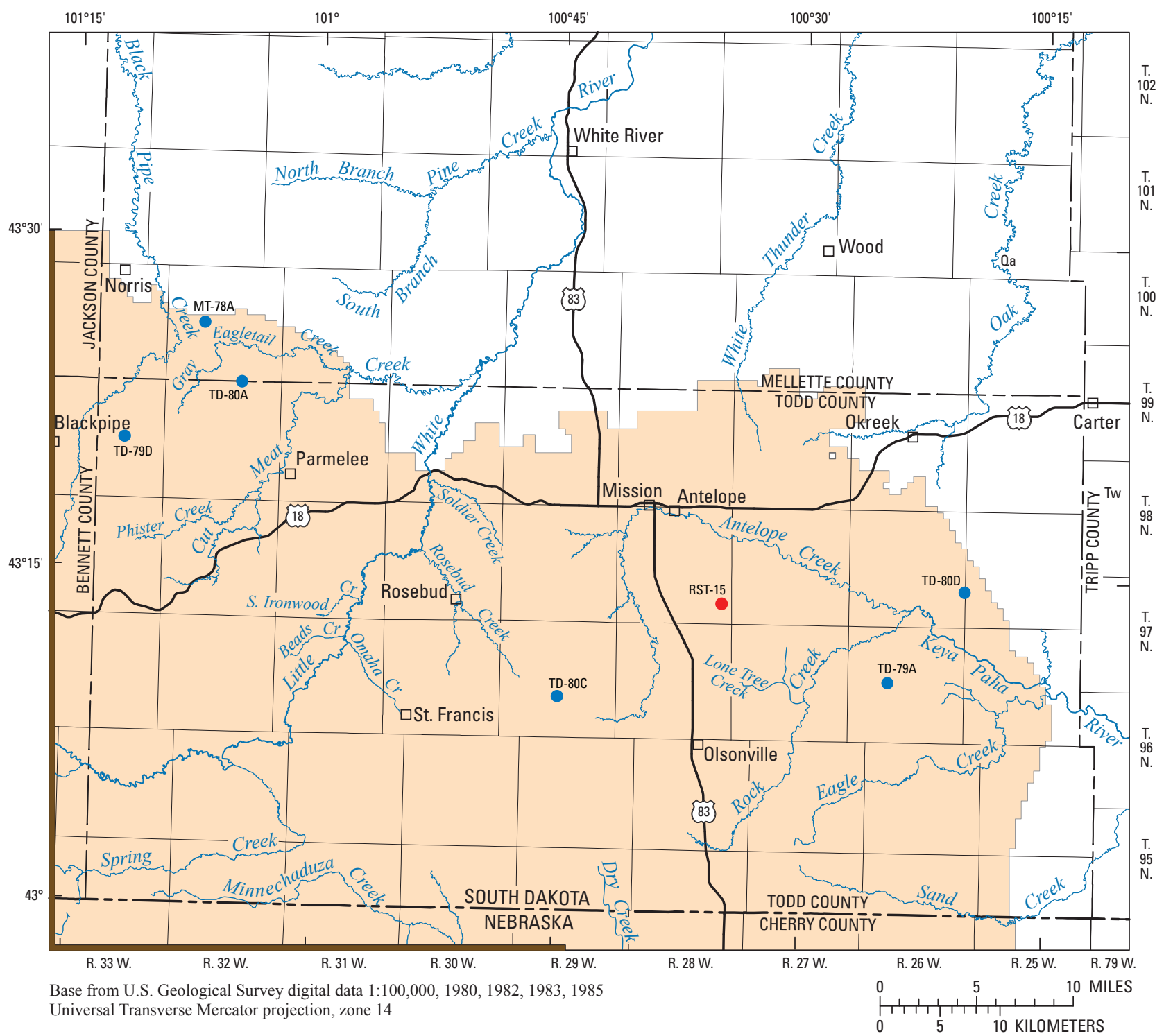

EXPLANATION

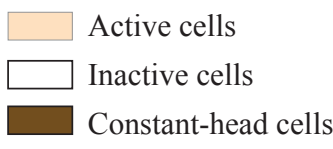
RST-15 Tribal observation well completed in Arikaree aquifer. Label is well identifier (table 7)
TD-80C State observation well completed in Arikaree aquifer. Label is well identifier (table 8)

Figure 10. Cell types in the Arikaree aquifer (layer 2) and observation wells completed in the Arikaree aquifer.

1978-2008) and $1.45 \mathrm{in} / \mathrm{yr}$ for the Arikaree aquifer (about 7.5 percent of average precipitation for 1978-2008), for a total rate of $255.4 \mathrm{ft}^{3} / \mathrm{s}$. Although recharge probably is spatially variable, a uniform distribution was assumed for each of the two recharge areas (fig. 8) because of insufficient data. A lower rate of recharge for the Arikaree aquifer than the Ogallala aquifer is consistent with the lower permeability of the Arikaree aquifer. Precipitation records were available for a National Weather Service Climatological Data station in the town of Mission (National Climatic Data Center, 2010; station 395620), which is located near the center of the study area.
For the transient simulation, the antecedent rainfall conditions were considered in estimating recharge. During a rainstorm, the preexisting soil moisture content heavily influences the effectiveness of precipitation in recharging groundwater. The amount of rain that has fallen prior to a rainfall event - the antecedent rainfall condition - largely determines soil moisture content. Heavy rains prior to an event can saturate the root zone and decrease evapotranspiration rates in the unsaturated zone. The amount of precipitation that is not removed by evapotranspiration commonly is referred to as effective precipitation in rainfall-runoff modeling. Neglecting 


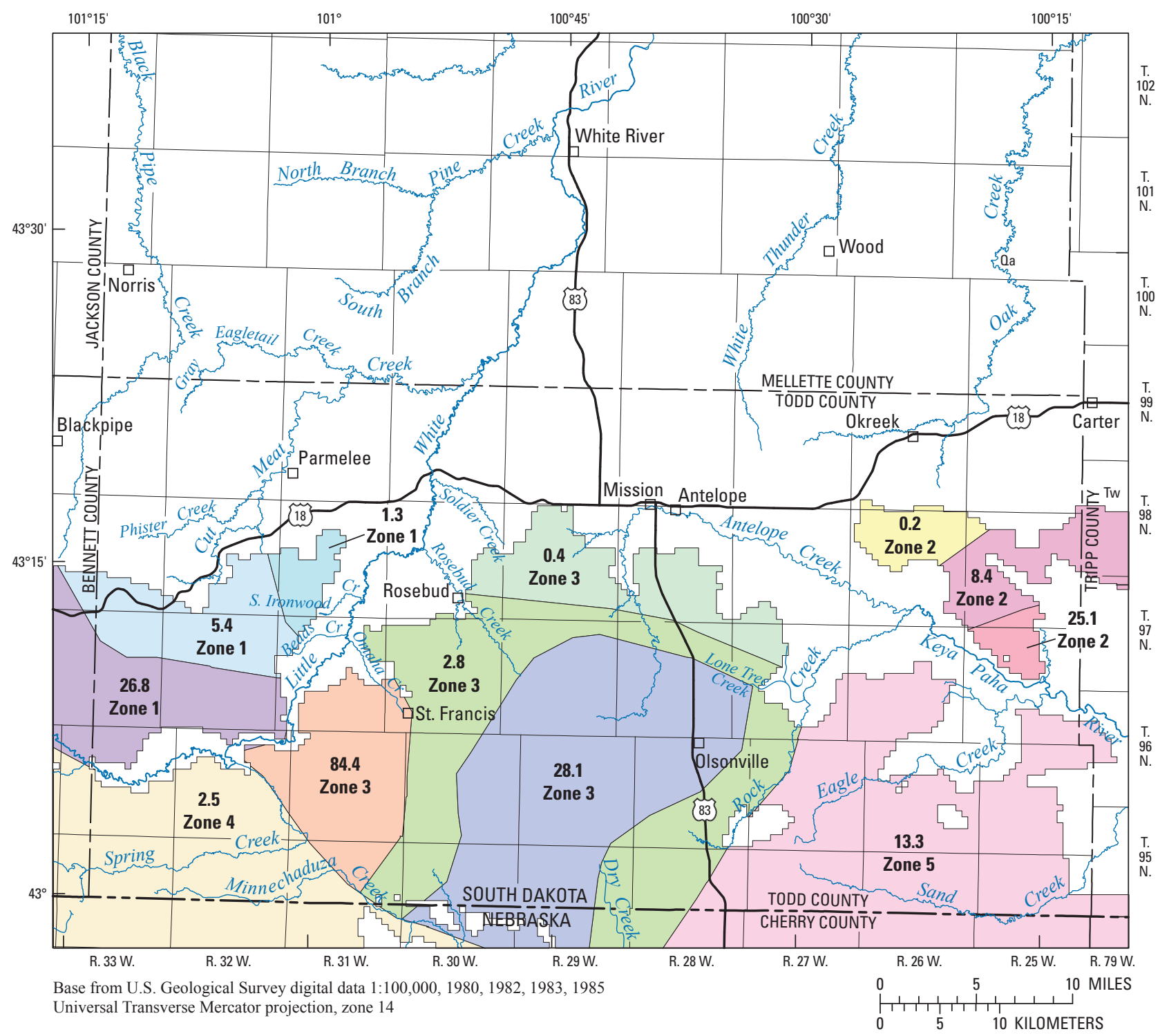

Figure 11. Estimated horizontal hydraulic conductivity of the Ogallala aquifer, in feet per day. Hydraulic conductivity of subareas within five major parameter zones are shown in each shaded area.

direct runoff, effective precipitation is synonymous with groundwater recharge. Direct runoff was assumed negligible on the outcrop of the Ogallala Formation and overlying surficial deposits because of the high permeability of these sandy media. Because of the low permeability of the Arikaree aquifer, some direct runoff was assumed to occur. The method of Jakeman and Hornberger (1993) can be used to calculate an antecedent rainfall index $s_{i}$, which weights the daily rainfall by previous rainfall. The weighting $s_{i}$ is distributed exponentially backward in time by

$$
\begin{aligned}
s_{i} & =c r_{i}+\left(1-a^{-1}\right) s_{i-1} \\
& =c\left[r_{i}+\left(1-a^{-1}\right) s_{i-1}+\left(1-a^{-1}\right)^{2} s_{i-2}+\ldots\right] \quad i=0,1, \ldots N, \quad 0>s_{i}>1,
\end{aligned}
$$

where $c$ is a normalizing parameter to limit $s_{i}$ to values between 0 and 1 [1/inches], $a$ adjusts the influence of antecedent conditions [dimensionless], $r_{i}$ is total daily rainfall [inches], and $i$ is the time step in days. Effective daily precipitation, or recharge, $u_{i}$ [inches] is then calculated by

$$
u_{i}=r_{i} S_{i}
$$

A value of $a=24$ was estimated by inverse modeling for a rainfall-runoff simulation in western South Dakota (Long, 2009) and was used to estimate recharge for the Ogallala aquifer. Values of $r_{i}$ were from the Weather Service Climatological Data station at Mission (National Climatic Data Center, 2010; station 395620). A value of $c=0.059$ for the Ogallala aquifer was used because this resulted in an average recharge rate equal to 15 percent of precipitation for the 30 -year period, which was consistent with the recharge rate estimated by the steady-state calibration. Recharge rates for the Ogallala 


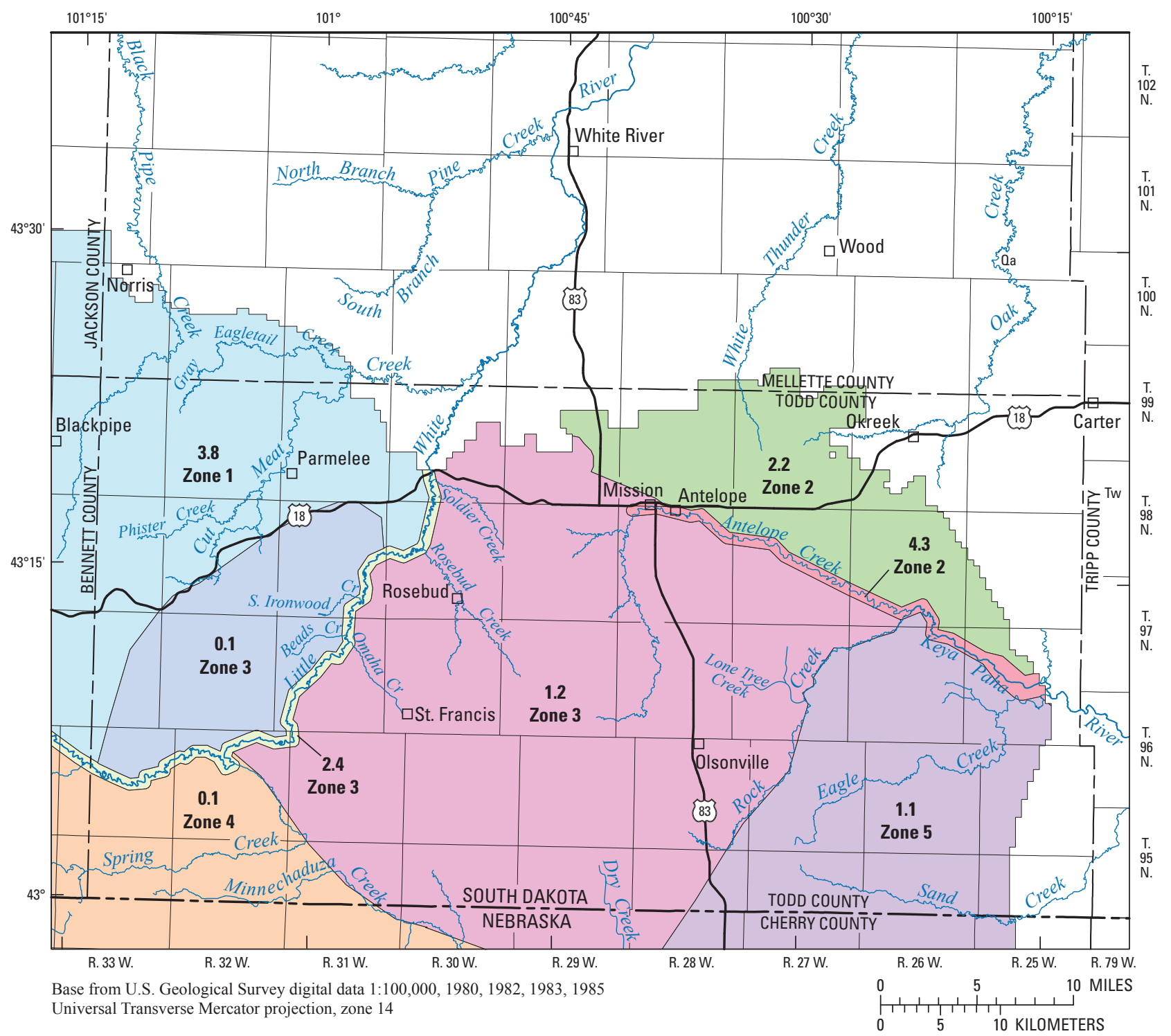

Figure 12. Estimated horizontal hydraulic conductivity of the Arikaree aquifer, in feet per day. Hydraulic conductivity of subareas within five major parameter zones are shown in each shaded area.

aquifer in total inches for each stress period were calculated as the sum of the effective daily precipitation $\left(u_{i}\right)$ for each stress period (table 6). As averages of daily values, recharge rates for each stress period ranged from 1.9 to 33.7 percent of precipitation for the Ogallala aquifer. Recharge by stress period for the Arikaree aquifer was estimated as one-half that of the Ogallala aquifer to be consistent with the steady-state simulation and to account for direct runoff.

\section{Discharge}

Various MODFLOW-2000 packages were used to simulate the discharge components of evapotranspiration, discharge to streams, and well withdrawals. The Evapotranspiration Package (McDonald and Harbaugh, 1988) was designed to simulate evapotranspiration from the uppermost aquifer in any given cell where the water table is within a specified depth below the land surface, referred to as the extinction depth. This extinction depth was set to $10 \mathrm{ft}$ in areas with woody vegetation (U.S. Geological Survey, 1955) and to $7 \mathrm{ft}$ elsewhere (fig. 14). The evapotranspiration rate is zero at the extinction depth and increases linearly to a maximum rate when the water level is at or above the land surface. The land-surface altitude for each cell was set to the average land-surface altitude for the area covered by the cell based on a 30-m digital elevation model.

The Evapotranspiration Package accounts for only part of total evapotranspiration because it affects groundwater at or below the water table only. Evapotranspiration of infiltrating or suspended groundwater in the unsaturated zone is not 
Table 6. Estimated recharge to the Ogallala aquifer, water years 1979-2008.

\begin{tabular}{|c|c|c|c|c|c|}
\hline $\begin{array}{l}\text { Stress } \\
\text { period }\end{array}$ & Water year & Months & $\begin{array}{l}\text { Precipitation } \\
\text { (inches) }\end{array}$ & $\begin{array}{l}\text { Recharge to Ogallala } \\
\text { aquifer (inches) }\end{array}$ & $\begin{array}{l}\text { Recharge as a percent- } \\
\text { age of precipitation }\end{array}$ \\
\hline 1 & 1979 & Oct.-Feb. & 1.48 & 0.03 & 1.9 \\
\hline 2 & 1979 & Mar.-May & 4.67 & .36 & 7.6 \\
\hline 3 & 1979 & June-Sept. & 11.50 & 2.33 & 20.3 \\
\hline 4 & 1980 & Oct.-Feb. & 3.20 & .25 & 7.9 \\
\hline 5 & 1980 & Mar--May & 3.34 & .19 & 5.6 \\
\hline 6 & 1980 & June-Sept. & 7.16 & .86 & 12.0 \\
\hline 7 & 1981 & Oct.-Feb. & 3.17 & .21 & 6.6 \\
\hline 8 & 1981 & Mar.-May & 5.92 & .66 & 11.1 \\
\hline 9 & 1981 & June-Sept. & 10.05 & 1.78 & 17.7 \\
\hline 10 & 1982 & Oct.-Feb. & 4.67 & .45 & 9.7 \\
\hline 11 & 1982 & Mar.-May & 9.84 & 1.85 & 18.8 \\
\hline 12 & 1982 & June-Sept. & 13.46 & 3.45 & 25.7 \\
\hline 13 & 1983 & Oct.-Feb. & 5.35 & .78 & 14.6 \\
\hline 14 & 1983 & Mar.-May & 8.47 & 1.28 & 15.1 \\
\hline 15 & 1983 & June-Sept. & 9.70 & 1.53 & 15.8 \\
\hline 16 & 1984 & Oct.-Feb. & 3.80 & .25 & 6.7 \\
\hline 17 & 1984 & Mar.-May & 6.67 & .65 & 9.8 \\
\hline 18 & 1984 & June-Sept. & 7.65 & 1.00 & 13.1 \\
\hline 19 & 1985 & Oct.-Feb. & 2.76 & .14 & 5.2 \\
\hline 20 & 1985 & Mar.-May & 3.11 & .17 & 5.5 \\
\hline 21 & 1985 & June-Sept. & 7.67 & .82 & 10.6 \\
\hline 22 & 1986 & Oct.-Feb. & 4.04 & .28 & 7.0 \\
\hline 23 & 1986 & Mar.-May & 8.34 & 1.06 & 12.7 \\
\hline 24 & 1986 & June-Sept. & 12.83 & 2.07 & 16.1 \\
\hline 25 & 1987 & Oct.-Feb. & 3.72 & .33 & 8.8 \\
\hline 26 & 1987 & Mar.-May & 8.40 & 1.12 & 13.4 \\
\hline 27 & 1987 & June-Sept. & 6.63 & .96 & 14.5 \\
\hline 28 & 1988 & Oct.-Feb. & 3.06 & .13 & 4.3 \\
\hline 29 & 1988 & Mar.-May & 6.57 & .82 & 12.5 \\
\hline 30 & 1988 & June-Sept. & 7.85 & 1.23 & 15.7 \\
\hline 31 & 1989 & Oct.-Feb. & 1.23 & .03 & 2.4 \\
\hline 32 & 1989 & Mar.-May & 2.96 & .13 & 4.3 \\
\hline 33 & 1989 & June-Sept. & 9.75 & 1.46 & 14.9 \\
\hline 34 & 1990 & Oct.-Feb. & 2.55 & .19 & 7.4 \\
\hline 35 & 1990 & Mar.-May & 6.70 & .67 & 10.1 \\
\hline 36 & 1990 & June-Sept. & 10.69 & 2.44 & 22.8 \\
\hline 37 & 1991 & Oct.-Feb. & 2.37 & .10 & 4.1 \\
\hline 38 & 1991 & Mar.-May & 10.70 & 2.22 & 20.8 \\
\hline 39 & 1991 & June-Sept. & 8.16 & 2.75 & 33.7 \\
\hline 40 & 1992 & Oct.-Feb. & 4.16 & .23 & 5.6 \\
\hline 41 & 1992 & Mar.-May & 1.99 & .09 & 4.6 \\
\hline 42 & 1992 & June-Sept. & 13.20 & 2.51 & 19.0 \\
\hline 43 & 1993 & Oct.-Feb. & 2.37 & .09 & 3.7 \\
\hline 44 & 1993 & Mar.-May & 5.40 & .57 & 10.6 \\
\hline 45 & 1993 & June-Sept. & 9.77 & 1.31 & 13.4 \\
\hline 46 & 1994 & Oct.-Feb. & 4.01 & .25 & 6.2 \\
\hline
\end{tabular}


Table 6. Estimated recharge to the Ogallala aquifer, water years 1979-2008.-Continued

\begin{tabular}{|c|c|c|c|c|c|}
\hline $\begin{array}{l}\text { Stress } \\
\text { period }\end{array}$ & Water year & Months & $\begin{array}{l}\text { Precipitation } \\
\text { (inches) }\end{array}$ & $\begin{array}{l}\text { Recharge to Ogallala } \\
\text { aquifer (inches) }\end{array}$ & $\begin{array}{l}\text { Recharge as a percent- } \\
\text { age of precipitation }\end{array}$ \\
\hline 47 & 1994 & Mar.-May & 3.75 & 0.36 & 9.7 \\
\hline 48 & 1994 & June-Sept. & 12.45 & 2.14 & 17.2 \\
\hline 49 & 1995 & Oct.-Feb. & 2.98 & .18 & 6.2 \\
\hline 50 & 1995 & Mar.-May & 10.35 & 1.69 & 16.3 \\
\hline 51 & 1995 & June-Sept. & 8.07 & 1.52 & 18.9 \\
\hline 52 & 1996 & Oct.-Feb. & 6.33 & 1.05 & 16.7 \\
\hline 53 & 1996 & Mar.-May & 7.03 & .91 & 13.0 \\
\hline 54 & 1996 & June-Sept. & 7.68 & 1.04 & 13.6 \\
\hline 55 & 1997 & Oct.-Feb. & 4.58 & .42 & 9.3 \\
\hline 56 & 1997 & Mar.-May & 6.47 & .77 & 12.0 \\
\hline 57 & 1997 & June-Sept. & 11.07 & 2.00 & 18.1 \\
\hline 58 & 1998 & Oct.-Feb. & 3.11 & .22 & 7.0 \\
\hline 59 & 1998 & Mar.-May & 5.66 & .50 & 8.8 \\
\hline 60 & 1998 & June-Sept. & 13.78 & 3.05 & 22.1 \\
\hline 61 & 1999 & Oct.-Feb. & 6.87 & .94 & 13.7 \\
\hline 62 & 1999 & Mar.-May & 8.87 & 1.48 & 16.7 \\
\hline 63 & 1999 & June-Sept. & 14.15 & 2.91 & 20.6 \\
\hline 64 & 2000 & Oct.-Feb. & 2.10 & .09 & 4.5 \\
\hline 65 & 2000 & Mar.-May & 9.61 & 1.98 & 20.6 \\
\hline 66 & 2000 & June-Sept. & 8.90 & 1.97 & 22.1 \\
\hline 67 & 2001 & Oct.-Feb. & 6.21 & .52 & 8.3 \\
\hline 68 & 2001 & Mar.-May & 8.32 & 1.20 & 14.5 \\
\hline 69 & 2001 & June-Sept. & 9.38 & 1.53 & 16.3 \\
\hline 70 & 2002 & Oct.-Feb. & 3.98 & .42 & 10.4 \\
\hline 71 & 2002 & Mar.-May & 4.36 & .35 & 8.0 \\
\hline 72 & 2002 & June-Sept. & 5.11 & .51 & 9.9 \\
\hline 73 & 2003 & Oct.-Feb. & 2.65 & .13 & 4.9 \\
\hline 74 & 2003 & Mar.-May & 5.30 & .49 & 9.3 \\
\hline 75 & 2003 & June-Sept. & 6.00 & .71 & 11.9 \\
\hline 76 & 2004 & Oct.-Feb. & 2.13 & .08 & 4.0 \\
\hline 77 & 2004 & Mar.-May & 7.29 & .79 & 10.8 \\
\hline 78 & 2004 & June-Sept. & 10.27 & 1.59 & 15.5 \\
\hline 79 & 2005 & Oct.-Feb. & 4.99 & 1.06 & 21.2 \\
\hline 80 & 2005 & Mar.-May & 10.23 & 1.93 & 18.9 \\
\hline 81 & 2005 & June-Sept. & 10.56 & 2.18 & 20.7 \\
\hline 82 & 2006 & Oct.-Feb. & 2.49 & .11 & 4.3 \\
\hline 83 & 2006 & Mar.-May & 5.59 & .61 & 10.8 \\
\hline 84 & 2006 & June-Sept. & 10.35 & 1.36 & 13.2 \\
\hline 85 & 2007 & Oct.-Feb. & 2.72 & .14 & 5.2 \\
\hline 86 & 2007 & Mar.-May & 7.76 & .94 & 12.1 \\
\hline 87 & 2007 & June-Sept. & 8.15 & 1.24 & 15.2 \\
\hline 88 & 2008 & Oct.-Feb. & 5.58 & .79 & 14.1 \\
\hline 89 & 2008 & Mar.-May & 6.32 & .66 & 10.5 \\
\hline 90 & 2008 & June-Sept. & 13.62 & 3.21 & 23.6 \\
\hline
\end{tabular}

${ }^{\mathrm{a} A v e r a g e ~ o f ~ d a i l y ~ v a l u e s ~ f o r ~ e a c h ~ s t r e s s ~ p e r i o d . ~}$ 


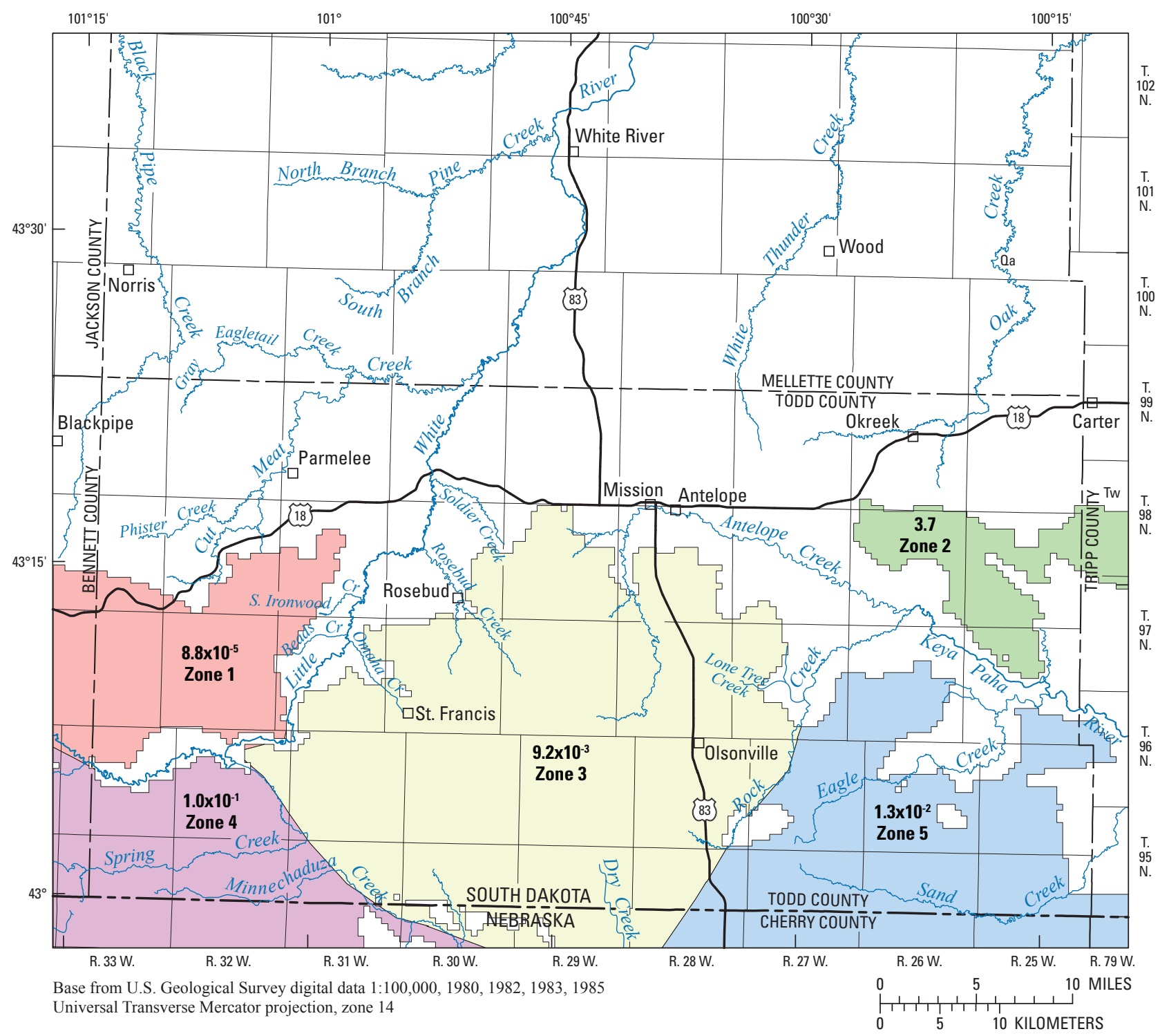

Figure 13. Estimated vertical hydraulic conductivity $(K)$, in feet per day, for the Arikaree aquifer in five parameter zones where overlain by the Ogallala aquifer.

accounted for. Estimation of the recharge rate as some percentage of total precipitation, as previously described, accounts for this remaining part of the evapotranspiration process.

Discharge to streams, which includes springs and seeps, was represented using two packages. The River Package in MODFLOW-2000 was used to simulate the hydraulic connection between groundwater and surface water by allowing streams to gain or lose water on the basis of the difference between the surrounding hydraulic head and stream stage through riverbed material. The hydraulic conductance of this material is defined by McDonald and Harbaugh (1988) as hydraulic conductivity of the material times the cross-sectional area of the stream reach divided by the streambed thickness. Estimated riverbed conductance was based on model calibration. Model cells were designated as river leakage cells along major streams and tributaries for six streams groups (fig. 14), which are (1) the Little White River and tributaries upstream from site 12 (fig. 7); (2) the Keya Paha River and tributaries; (3) Black Pipe Creek; (4) Gray Eagle and Cut Meat Creeks; (5) Sand Creek; and (6) Minnechaduza and Dry Creeks. River leakage cells were placed in stream reaches that are at or below the estimated potentiometric surface for the recharge area of the aquifer upon which the reach is located (figs. 4 and 5). Above these altitudes, streams are dry except during intense storms. Digital elevation data were used to determine stream locations, and thus river leakage cells do not always coincide exactly with streams shown on figure 14 .

The Drain Package simulated springs discharging from the Ogallala aquifer along the banks of the Little White River and along the northern edge of the Arikaree aquifer (fig. 14). The Drain Package is similar to the River Package except that drain cells can only take water out of the aquifer, whereas river 


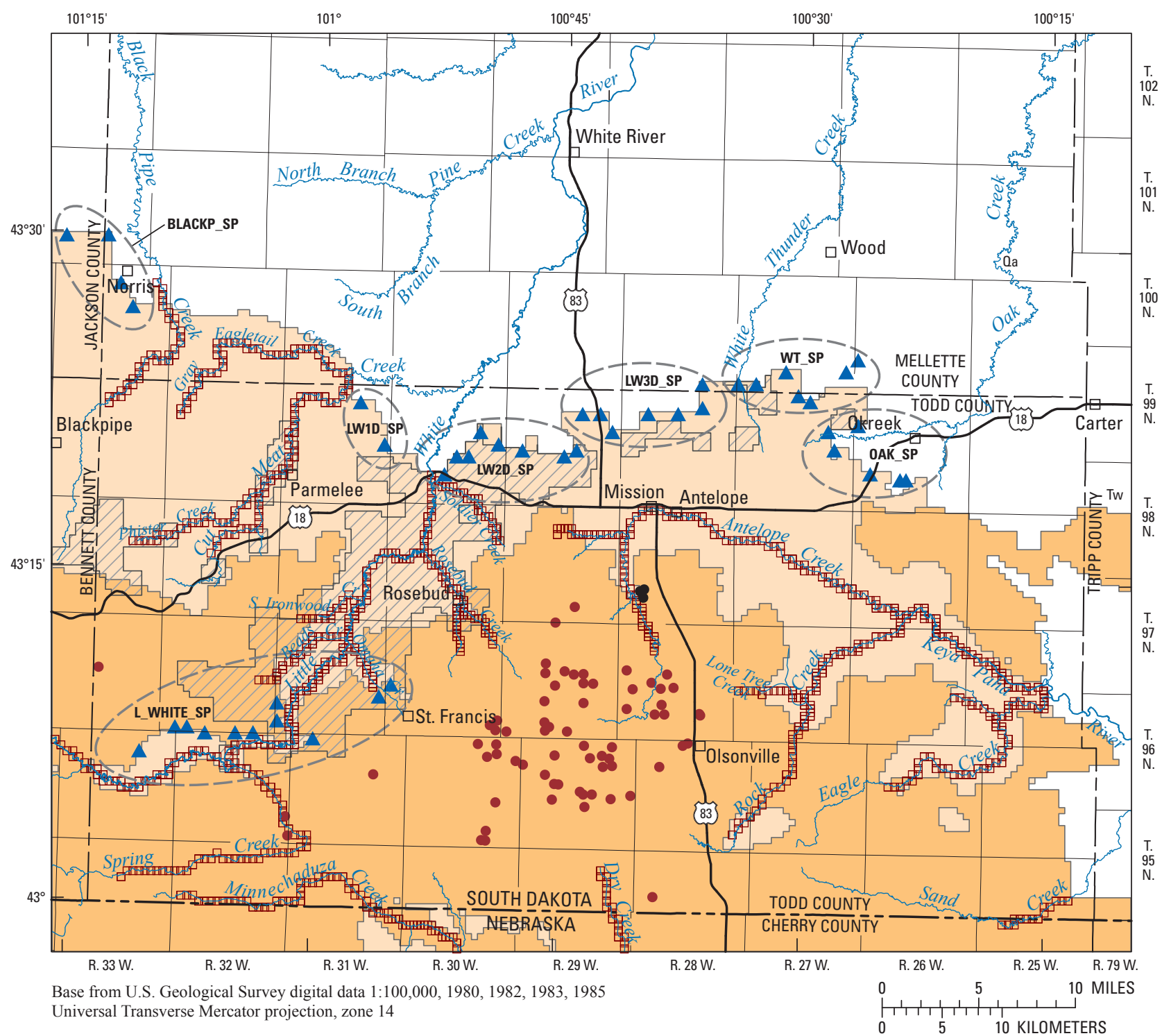

EXPLANATION

Cell simulating river leakage

- Cell simulating spring discharge

- Water-supply well in Ogallala aquifer

- Water-supply well in Arikaree aquifer Wt_SP (_) Spring group showing parameter name

Figure 14. River cells, evapotranspiration zones, spring cells, and water-supply wells in the Ogallala and Arikaree aquifers.

cells can also recharge the aquifer (McDonald and Harbaugh, 1988). Model cells were designated as drain cells for seven spring groups (fig. 14), and drain (spring) conductance was estimated by model calibration for each spring group.

Well withdrawals were simulated with the Well Package (McDonald and Harbaugh, 1988) to withdraw water from each well at a specified rate. Well withdrawals used in the transient simulation are listed in table 4, and locations are shown in figures 8 and 14. Because water use was negligible from October through May, total annual withdrawals were assigned to the summer stress periods only (June-September). For the steady-state calibration, the average withdrawal rate was calculated as $11.6 \mathrm{ft}^{3} / \mathrm{s}$.

\section{Model Calibration}

The steady-state simulation was calibrated to the estimated average water levels shown in figures 4 and 5 and to the estimated base flows listed in table 3 . The transient model was 
Table 7. Selected data for Tribal observation wells in the study area.

[Hydraulic heads are estimated averages for water years 1979-98. NGVD of 1929, National Geodetic Vertical Datum of 1929]

\begin{tabular}{|c|c|c|c|c|c|c|c|c|}
\hline $\begin{array}{c}\text { Well } \\
\text { name } \\
\text { (figs. } 9 \\
\text { and 10) }\end{array}$ & $\begin{array}{c}\text { Site identification } \\
\text { numer }\end{array}$ & Legal location & Aquifer & $\begin{array}{l}\text { Land surface } \\
\text { altitude (feet } \\
\text { above NGVD } \\
\text { of 1929) }\end{array}$ & $\begin{array}{l}\text { Well } \\
\text { depth } \\
\text { (feet) }\end{array}$ & $\begin{array}{c}\text { Average } \\
\text { measured } \\
\text { hydraulic } \\
\text { head (feet } \\
\text { above NGVD } \\
\text { of 1929) }\end{array}$ & $\begin{array}{l}\text { Steady-state } \\
\text { simulated } \\
\text { hydraulic } \\
\text { head (feet } \\
\text { above NGVD } \\
\text { of 1929) }\end{array}$ & Residuala $^{\mathrm{a}}$ \\
\hline RST-3 & 430309100570901 & 36N31W34DBBC & Ogallala & 2,920 & 91 & 2,865 & 2,833 & -32 \\
\hline RST-6 & 430501100504901 & $36 \mathrm{~N} 30 \mathrm{~W} 22 \mathrm{CBBB}$ & Ogallala & 2,888 & 137 & 2,858 & 2,860 & 2 \\
\hline RST-7 & 430415100451401 & 36N29W29ACAA & Ogallala & 2,870 & 134 & 2,851 & 2,830 & -21 \\
\hline RST-8 & 430258100471401 & 36N30W36DDDA & Ogallala & 2,885 & 123 & 2,836 & 2,846 & 10 \\
\hline RST-9 & 430100100460501 & 35N29W18AAAA & Ogallala & 2,870 & 84 & 2,831 & 2,844 & 13 \\
\hline RST-13 & 430755100582301 & 37N29W31DACC & Ogallala & 2,921 & 275 & 2,815 & 2,824 & 9 \\
\hline RST-15 & 431342100344101 & 38N28W36ABCB & Arikaree & 2,620 & 73 & 2,609 & 2,577 & -32 \\
\hline RST-16 & 430820100371401 & 37N28W34ABDA & Ogallala & 2,783 & 171 & 2,725 & 2,733 & 8 \\
\hline RST-17 & 431027100333001 & 37N27W18DDAB & Ogallala & 2,609 & 53 & 2,605 & 2,613 & 8 \\
\hline RST-18 & 430702100330501 & $36 \mathrm{~N} 28 \mathrm{~W} 12 \mathrm{AABA}$ & Ogallala & 2,806 & 215 & 2,660 & 2,678 & 18 \\
\hline RST-19 & 430243100371701 & 36N28W33BDDD & Ogallala & 2,753 & 75 & 2,723 & 2,732 & 9 \\
\hline RST-20 & 430122100344501 & $35 \mathrm{~N} 28 \mathrm{~W} 11 \mathrm{DBBB}$ & Ogallala & 2,728 & 94 & 2,711 & 2,711 & 0 \\
\hline RST-21 & 430057100275401 & 35N27W14BAAB & Ogallala & 2,690 & 84 & 2,671 & 2,636 & -35 \\
\hline RST-22 & 430335100241401 & 36N26W32BBAA & Ogallala & 2,619 & 78 & 2,589 & 2,594 & 5 \\
\hline
\end{tabular}

aResidual is the difference between simulated hydraulic head and average measured hydraulic head.

calibrated to water levels measured frequently in Tribal and State observation wells during water years 1979-2008.

\section{Steady-State Simulation}

Steady-state conditions were numerically approximated by simulating a 100-year stress period in transient mode with constant recharge and discharge rates. This method was more numerically stable and used fewer iterations than the equivalent simulation in steady-state mode. The potentiometric surface from the steady-state simulation established initial conditions for the transient simulation.

Calibration of the steady-state model primarily was accomplished by applying what is commonly known as inverse modeling. This method is an efficient way to determine an optimum set of parameter values that minimize the residuals between measured and simulated flow metrics, such as hydraulic head, base flow, and spring flow. Parameters estimated by inverse modeling were those describing hydraulic conductivity $(K)$, recharge, maximum evapotranspiration, riverbed conductance, and spring conductance.

Optimization of parameter values by inverse modeling was accomplished by linking the parameter estimation software PEST (Doherty, 2004) with MODFLOW-2000. PEST is an iterative parameter estimation process that applies nonlinear estimation techniques described by Levenberg (1944), Marquardt (1963), and Doherty (2004). This allows a nonlinear problem to be linearized in relation to the best parameter set for the current iteration. A new set of parameters is then estimated in an attempt to improve model calibration, and the process is repeated until the residuals are minimized. Parameter sensitivities and confidence intervals are determined by calculating the derivatives of all observations with respect to all parameters. This calibration approach was considered an improvement over the trial-and-error methods because it was more efficient and objective and provided a statistical assessment of model uncertainty, including confidence intervals on estimated parameter values and a matrix of parameter correlation coefficients. 
Table 8. Selected data for State observation wells in the study area.

[Hydraulic heads are estimated averages for water years 1979-98. NGVD of 1929, National Geodetic Vertical Datum of 1929]

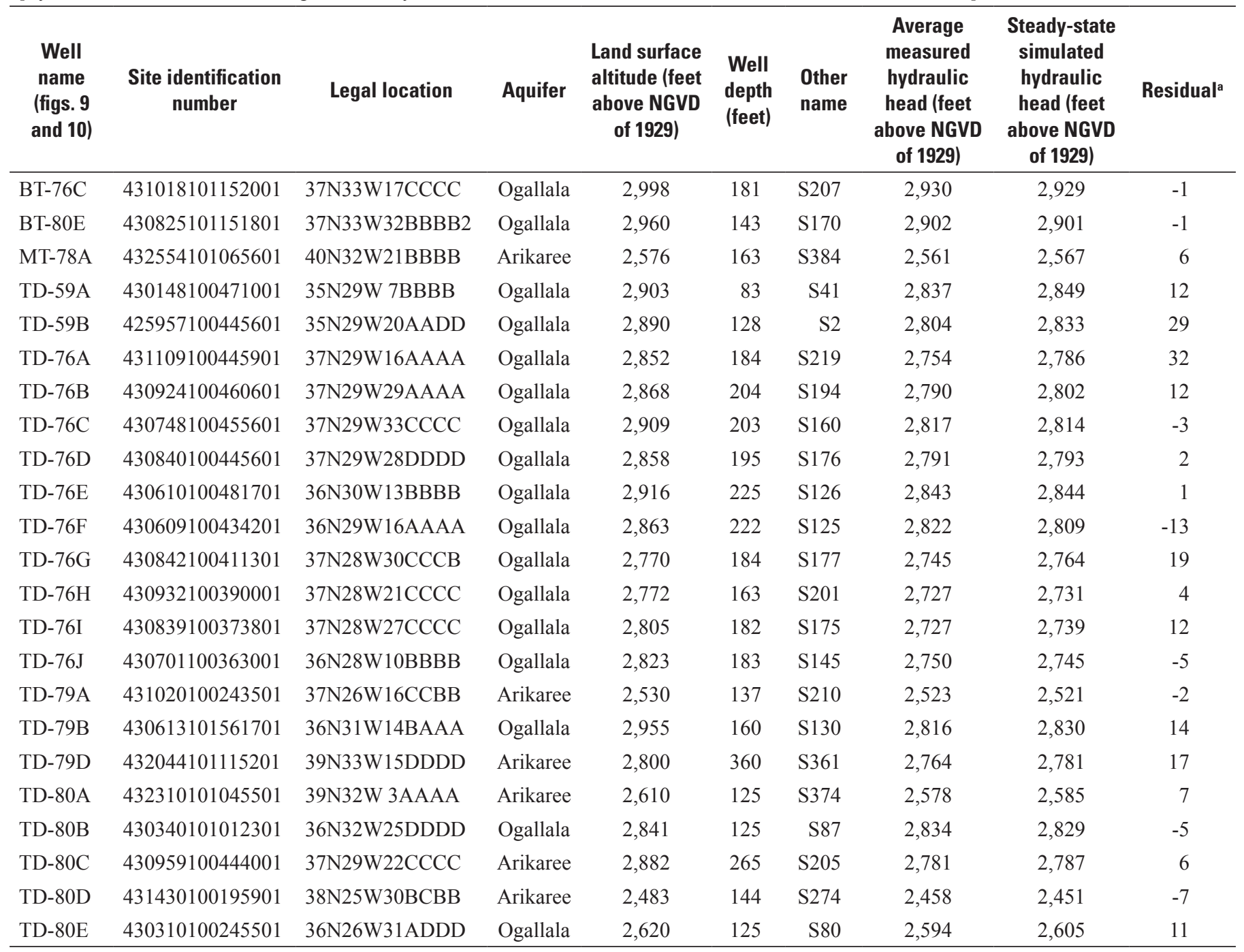

${ }^{a}$ Residual is the difference between simulated hydraulic head and average measured hydraulic head.

The criterion for estimating optimum parameter values was to achieve a minimum value for the sum of the squared and weighted residuals, or differences, between simulated and observed hydraulic heads and base flows in streams. This is referred to as the objective function. Water-level measurements for 383 wells that were used for estimation of potentiometric surfaces of the Ogallala and Arikaree aquifers (figs. 4 and 5) were used in calibration of the steady-state model. These wells included 44 observation wells with long-term water-level records that also were used for calibration of the transient model. The rest were wells mainly used for water supply. The observation wells included 21 Tribal wells, of which 20 were completed in the Ogallala aquifer and 1 was completed in the Arikaree aquifer, and 23 State wells, of which 17 were completed in the Ogallala aquifer and 6 were completed in the Arikaree aquifer (figs. 9 and 10). Selected data for the Tribal and State observation wells are shown in table 7 and table 8 , respectively. The model also was calibrated to estimated base flow in streams. As described in the "Conceptual Model" section, estimated base-flow values for the Little White River, Keya Paha River, Cut Meat Creek, Black Pipe Creek, Minnechaduza Creek, and Sand Creek were $49,23,1.7,1.2,3.0$, and $3.9 \mathrm{ft}^{3} / \mathrm{s}$, respectively.

The primary calibration objective was to minimize the objective function. A second calibration objective for the steady-state simulation was to have the simulated potentiometric surfaces and hydraulic gradients generally resemble those of the estimated average potentiometric surfaces (water years 1979-98). The simulated steady-state potentiometric surfaces (figs. 15 and 16) are similar to the estimated average potentiometric surfaces (figs. 4 and 5) in comparisons of both hydraulic heads and gradients.

Simulated hydraulic heads matched observed values to within $\pm 50 \mathrm{ft}$ for 93 percent of the 383 wells used in the steady-state calibration. Fifty feet is about 7 percent of the total hydraulic head relief for the estimated average 


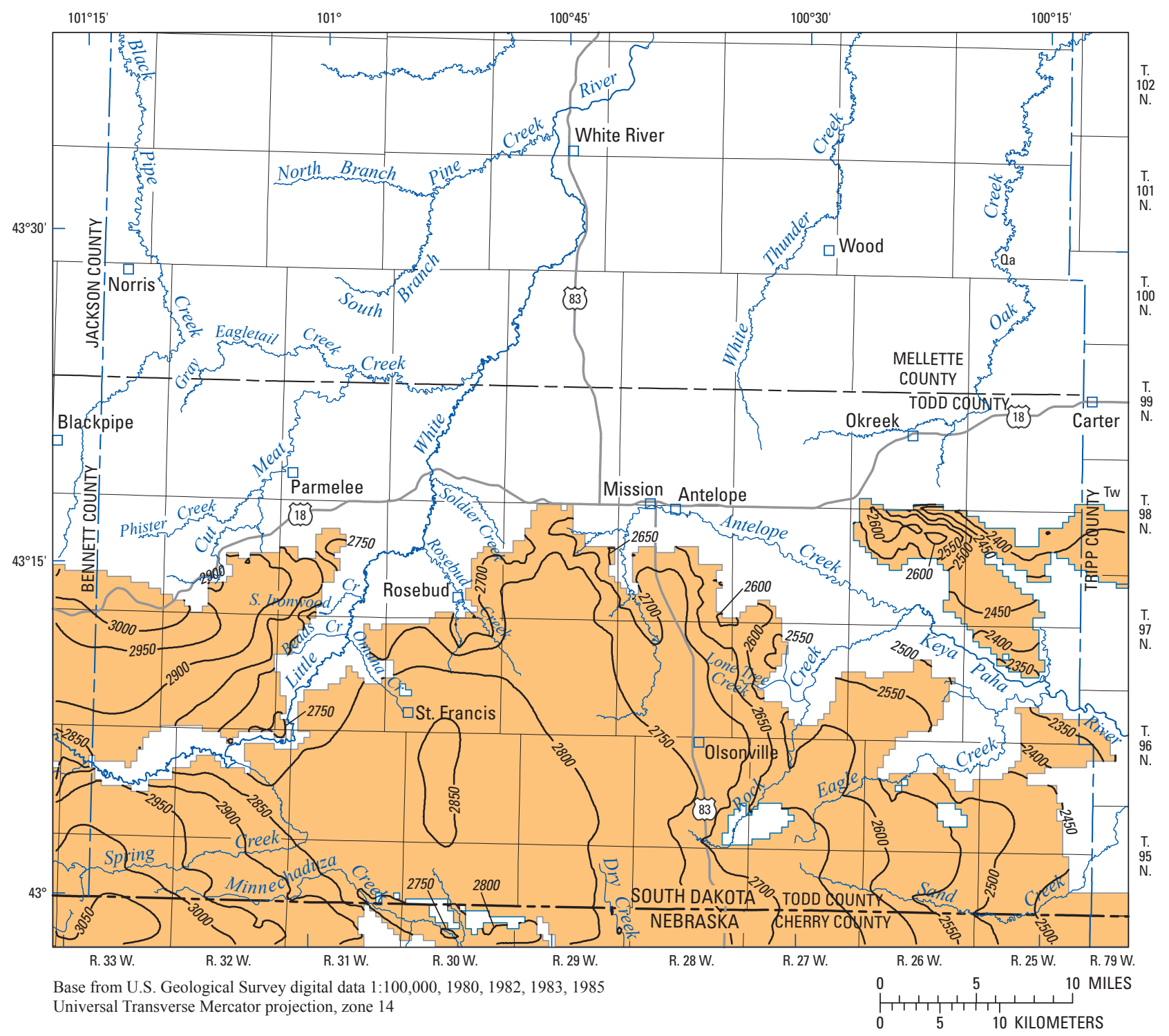

EXPLANATION

Ogallala aquifer active cells

-2750 - Simulated potentiometric contour-Shows average altitude at which water level would have stood in tightly cased wells, water years 1979-98. Contour interval is 50 feet. Datum is NGVD of 1929

Figure 15. Potentiometric surface of the Ogallala aquifer for steady-state simulation.

potentiometric surfaces in the model area, which is about $780 \mathrm{ft}$ for the Ogallala aquifer and $720 \mathrm{ft}$ for the Arikaree aquifer. A histogram shows the distribution of the hydraulichead residuals for the 383 wells (fig. 17). Results for the 44 observation wells was better than for all 383 wells. Simulated hydraulic heads for observation wells were within $\pm 40 \mathrm{ft}$ of the observed hydraulic heads for 98 percent of these wells. The root mean square error (RMSE) for all 383 wells was $27.3 \mathrm{ft}$. The mean error was $4.3 \mathrm{ft}$, which indicates a slight model bias toward overestimating hydraulic head values. For the observation wells only, the RMSE was $15.8 \mathrm{ft}$, and the mean error was $3.4 \mathrm{ft}$. A linear regression analysis of simulated and observed water levels for all 383 wells (fig. 18) yielded an $\mathrm{R}^{2}$ value (coefficient of determination) of 0.97 . The total simulated base flow was $73.3 \mathrm{ft}^{3} / \mathrm{s}$, which is about 10 percent less than the total estimated base flow of $81.8 \mathrm{ft}^{3} / \mathrm{s}$ (table 9).

Because a large number of estimated parameters can result in high parameter correlations and large parameter confidence intervals, the horizontal $K$ areas were grouped into five major parameter zones for each model layer (figs. 11 and 


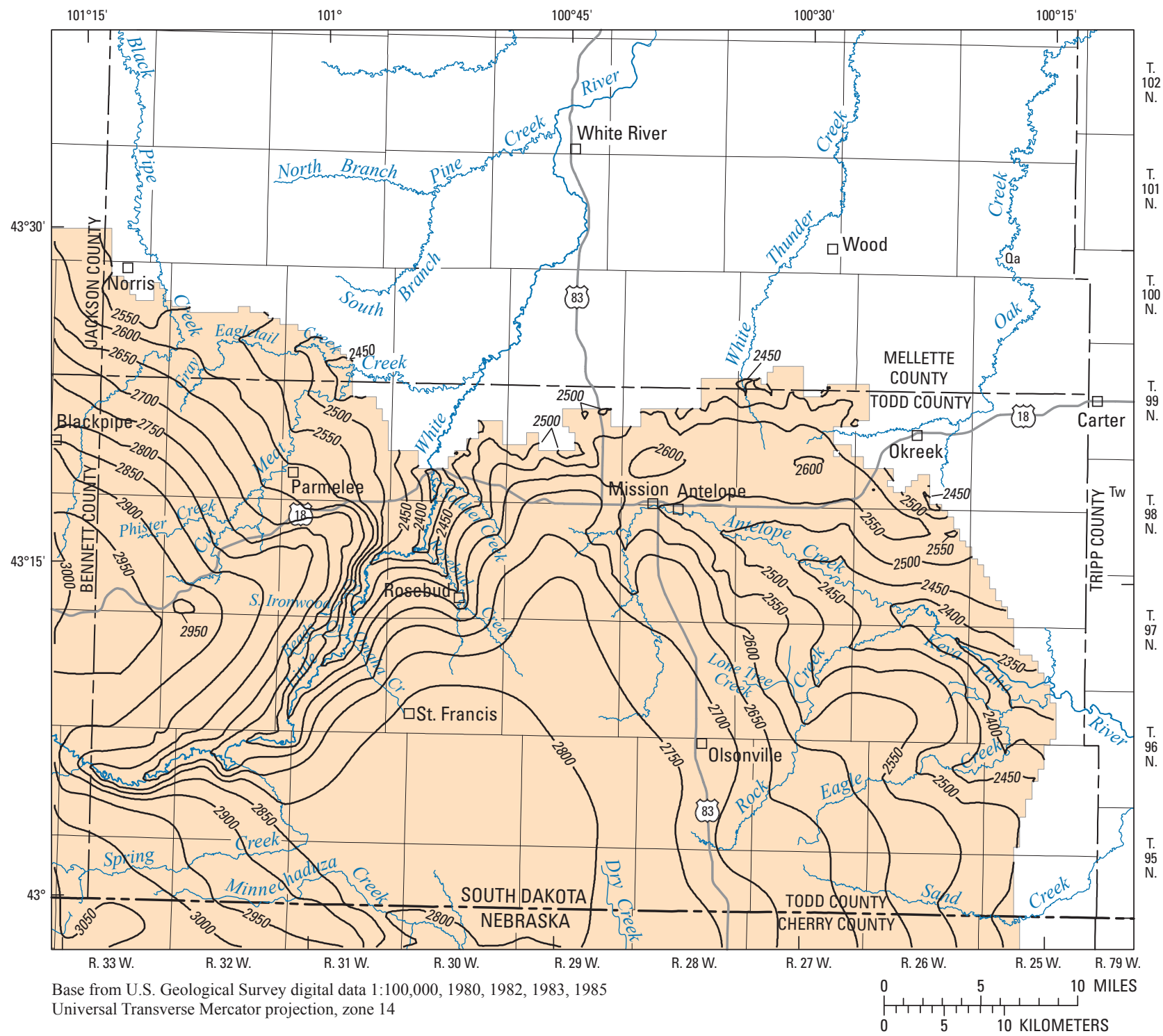

EXPLANATION

Arikaree aquifer active cells

— 2500 - Simulated potentiometric contour-Shows average altitude at which water level would have stood in tightly cased wells, water years 1979-98. Contour interval is 50 feet. Datum is NGVD of 1929

Figure 16. Potentiometric surface of the Arikaree aquifer for steady-state simulation.

12). One parameter value was estimated by inverse modeling for each of these 10 zones. Prior to executing the inverse modeling process, these parameter values were multiplied by values assigned to subareas within the parameter zones to allow variation within parameter zones. Subarea values were assigned on the basis of specific capacities of wells (Long and others, 2003) and the assumption that horizontal $K$ for the Arikaree aquifer is highest near streams (figs. 11 and 12). Trial-and-error was used to further refine subarea values in an iterative process with inverse modeling in order to minimize the objective function. As a result of this calibration process, an additional subarea, which was not part of the previously published model, was delineated in the northeastern part of zone 1 (horizontal $K$ of $1.3 \mathrm{ft} / \mathrm{d}$, fig. 11 ).

The shaded subareas in figures 11 and 12 show the results of this multiplication, which are the final horizontal $K$ values used in the steady-state simulation. Vertical $K$ was assumed to be homogeneous within each of the five parameter zones for the Arikaree aquifer (fig. 13), and a uniform vertical $K$ value was applied to the Ogallala aquifer because parameter 


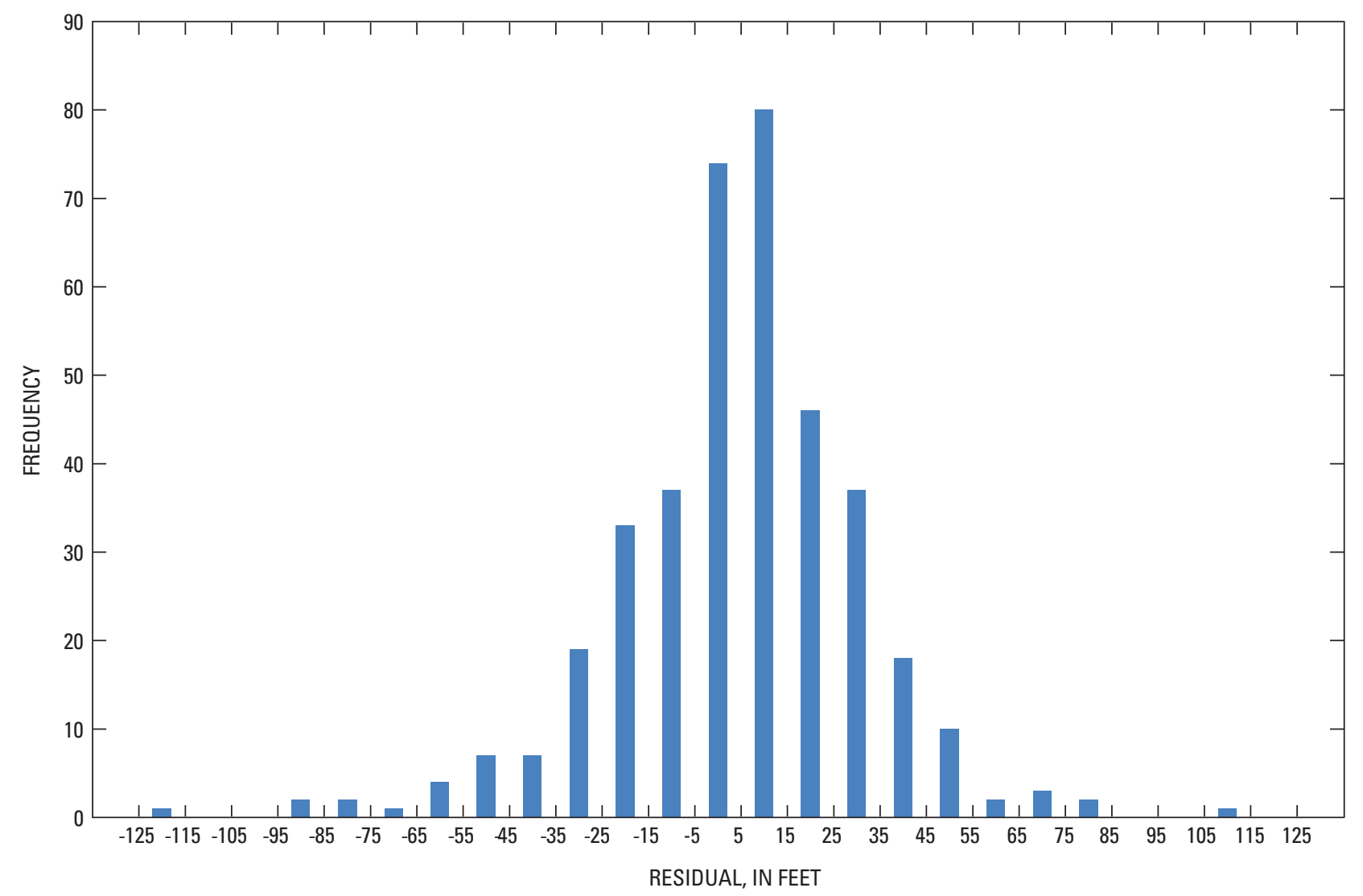

Figure 17. Histogram of residuals of average observed and steady-state simulated hydraulic head for 383 wells, water years 1979-98.

estimates for only one of the two intervening layers need to be adjusted for calibration. This resulted in a total of six parameter values for vertical $K$. Greater discretization of horizontal or vertical $K$ might have further minimized the objective function by adjusting $K$ near individual wells or small groups of wells, but the available data did not support this degree of

Table 9. Comparison of steady-state simulated and estimated base flows for six surface-water drainage basins.

$\left[\mathrm{ft}^{3} / \mathrm{s}\right.$, cubic feet per second $]$

\begin{tabular}{lcc}
\hline \multirow{1}{c}{ Stream } & \multicolumn{2}{c}{ Base flow $\left(\mathbf{f t}^{3} / \mathbf{s}\right)$} \\
\cline { 2 - 3 } & Estimated & $\begin{array}{c}\text { Steady-state } \\
\text { simulated }\end{array}$ \\
\hline Little White River & 49.0 & 36.7 \\
Keya Paha River & 23.0 & 20.0 \\
Cut Meat Creek & 1.7 & 8.4 \\
Black Pipe Creek & 1.2 & 1.3 \\
Minnechaduza Creek & 3.0 & 3.2 \\
Sand Creek & 3.9 & 3.8 \\
Total & 81.8 & 73.3 \\
\hline
\end{tabular}

${ }^{\mathrm{a}}$ Net outflow. Includes spring flow along river banks. detail. Therefore, the calibration accuracy obtained using these parameter zones and subareas was considered sufficient to fulfill the objectives of this study.

The remaining parameter categories were recharge, maximum evapotranspiration, riverbed conductance, and spring conductance. Two recharge rates were estimated by inverse modeling: one rate for the Ogallala aquifer recharge area and a second rate for the Arikaree aquifer recharge area (fig. 8). A single value applied to the entire model for the maximum evapotranspiration rate was estimated by inverse modeling. A value for each of the six riverbed conductance cell groups and seven spring conductance cell groups was estimated by inverse modeling (fig. 14). With these additional parameter values, there were a total of 32 values to be estimated by inverse modeling for the steady-state simulation (table 10).

These 32 parameter values were estimated during an initial execution of the inverse modeling process. However, diagnostics, such as large parameter confidence intervals, insensitivity of several parameters, and many highly correlated parameters, indicated the need to group some parameters together and thereby reduce the total number of parameters to be estimated directly by inverse modeling. This was accomplished by tying parameters together, a method in which a 


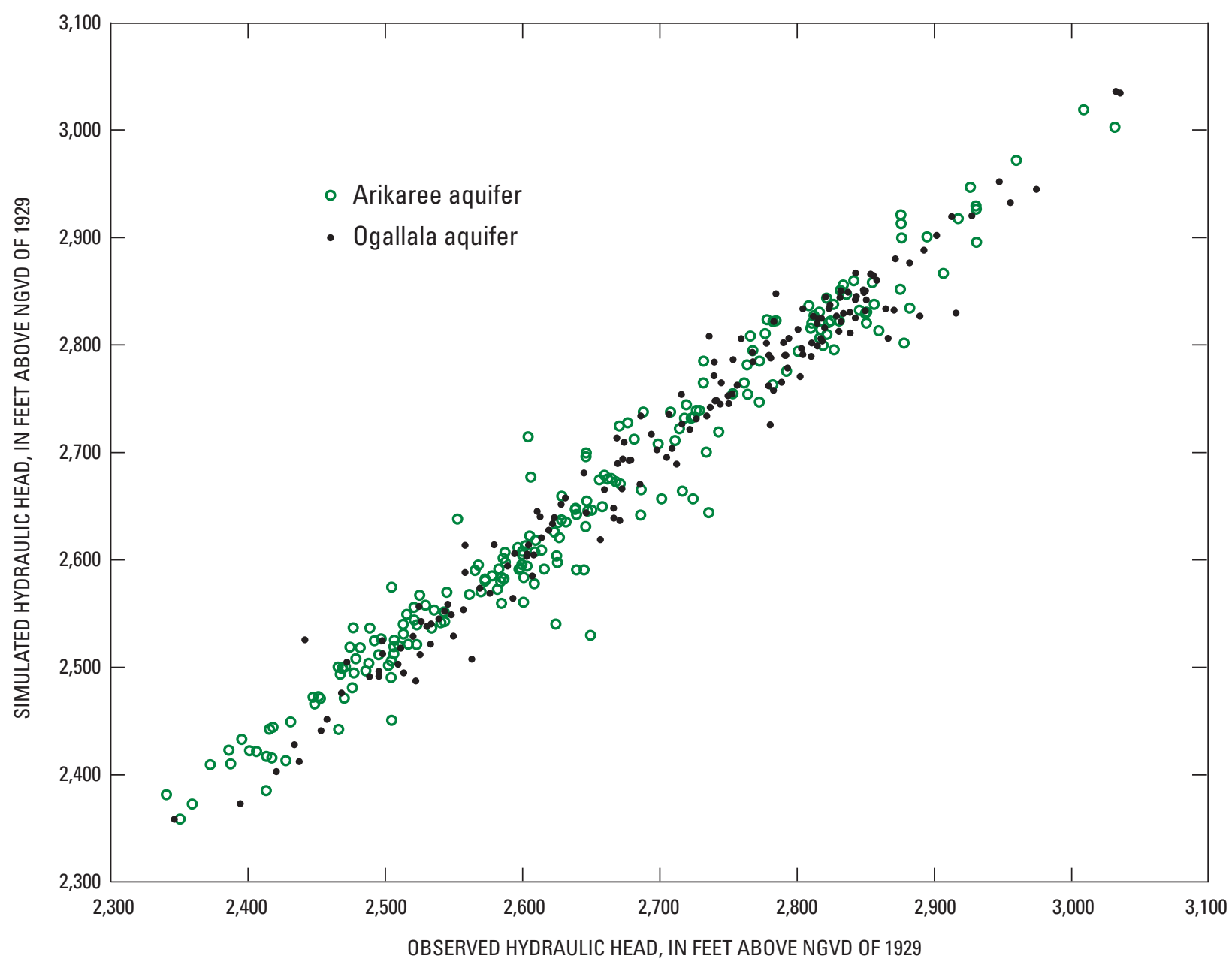

Figure 18. Linear regression of average observed and simulated steady-state hydraulic heads for 383 wells, water years 1979-98.

parameter is tied to an independent parameter, which can be adjusted during the inverse modeling process. The two parameters maintain a constant ratio based on their starting values, but only the independent parameter takes an active role in the inverse modeling process. Parameter confidence intervals are calculated for independent parameters but not for tied parameters (table 10). The least sensitive parameters were tied to more sensitive parameters of the same type. The 32 parameter values estimated during the initial execution were used as starting values for the independent and tied parameters.

Recharge to the Arikaree aquifer was tied to recharge to the Ogallala aquifer. All of the vertical $K$ parameters for the Arikaree aquifer were tied to the single vertical $K$ parameter for the Ogallala aquifer. Riverbed conductance parameters for small drainage basins were tied to the Little White and Keya Paha River conductance parameters, and most of the spring conductance parameters were tied to one spring. This resulted in 15 independent parameters estimated directly by inverse modeling and 17 parameters estimated indirectly by being tied to 7 of the independent parameters (table 10). The range of values within which each parameter could be estimated was limited to what was considered physically reasonable. This prevented PEST from estimating unreasonable parameter values simply because they reduced the value of the objective function.

PEST calculated 95-percent confidence intervals on parameters, which indicates 95 percent confidence that a parameter value within this range results in the smallest possible objective function (table 10). In the final execution, the largest confidence intervals were associated with parameters WT_SP, VKA1_1, KEYA_PAHA, and L_WHITE_SP. It is noted that these confidence intervals rely on an assumption of linearity, which might not be valid at wide confidence limits. Other parameters, for example RECH1, had small confidence intervals indicating a high degree of confidence in these estimates relative to some other parameters. The estimated recharge rates for the Ogallala and Arikaree aquifers of 2.91 and $1.45 \mathrm{in} / \mathrm{yr}$, respectively, are about 15 and 7.5 percent of average precipitation for the simulated period.

The water budget for the steady-state simulation balanced (inflows minus outflows) with a discrepancy of 0.2 percent (table 11). Total inflow from model constant-head boundaries 


\section{Simulated Groundwater Flow in the Ogallala and Arikaree Aquifers, Rosebud Indian Reservation Area}

Table 10. Parameter values estimated by inverse modeling for the steady-state simulation.

[ft/d, feet per day; $\mathrm{ft}^{2} / \mathrm{d}$, feet squared per day; in/yr, inches per year; --, not applicable]

\begin{tabular}{|c|c|c|c|c|c|c|c|}
\hline \multirow{2}{*}{$\begin{array}{l}\text { Parameter } \\
\text { name }\end{array}$} & \multirow[b]{2}{*}{ Estimated value } & \multicolumn{2}{|c|}{ 95-percent confidence intervals } & \multirow[b]{2}{*}{ Units } & \multirow[b]{2}{*}{ Tied to } & \multirow{2}{*}{$\begin{array}{c}\text { Value applied } \\
\text { to transient } \\
\text { model }\end{array}$} & \multirow[b]{2}{*}{ Description } \\
\hline & & Lower limit & Upper limit & & & & \\
\hline HK1_1 & 48.81 & 21.98 & 108.40 & $\mathrm{ft} / \mathrm{d}$ & -- & Yes & $\begin{array}{l}\text { Horizontal hydraulic con- } \\
\text { ductivity layer } 1 \text {, zone } 1 .\end{array}$ \\
\hline HK1_2 & 15.25 & 1.47 & 158.41 & $\mathrm{ft} / \mathrm{d}$ & -- & Yes & $\begin{array}{l}\text { Horizontal hydraulic con- } \\
\text { ductivity layer 1, zone } 2 \text {. }\end{array}$ \\
\hline HK1_3 & 25.61 & 12.30 & 53.32 & $\mathrm{ft} / \mathrm{d}$ & -- & Yes & $\begin{array}{l}\text { Horizontal hydraulic con- } \\
\text { ductivity layer } 1 \text {, zone } 3 \text {. }\end{array}$ \\
\hline HK1_4 & 4.54 & -- & -- & $\mathrm{ft} / \mathrm{d}$ & HK1_5 & Yes & $\begin{array}{l}\text { Horizontal hydraulic con- } \\
\text { ductivity layer } 1 \text {, zone } 4 \text {. }\end{array}$ \\
\hline HK1_5 & 40.33 & 10.45 & 155.58 & $\mathrm{ft} / \mathrm{d}$ & -- & Yes & $\begin{array}{l}\text { Horizontal hydraulic con- } \\
\text { ductivity layer } 1 \text {, zone } 5 \text {. }\end{array}$ \\
\hline HK2_1 & 2.52 & .42 & 15.07 & $\mathrm{ft} / \mathrm{d}$ & -- & Yes & $\begin{array}{l}\text { Horizontal hydraulic con- } \\
\text { ductivity layer } 2 \text {, zone } 1 .\end{array}$ \\
\hline HK2_2 & 1.44 & .58 & 3.58 & $\mathrm{ft} / \mathrm{d}$ & -- & Yes & $\begin{array}{l}\text { Horizontal hydraulic con- } \\
\text { ductivity layer } 2 \text {, zone } 2 \text {. }\end{array}$ \\
\hline HK2_3 & .81 & .69 & .95 & $\mathrm{ft} / \mathrm{d}$ & -- & Yes & $\begin{array}{l}\text { Horizontal hydraulic con- } \\
\text { ductivity layer } 2 \text {, zone } 3 \text {. }\end{array}$ \\
\hline HK2_4 & .06 & -- & -- & $\mathrm{ft} / \mathrm{d}$ & HK2_5 & Yes & $\begin{array}{l}\text { Horizontal hydraulic con- } \\
\text { ductivity layer } 2 \text {, zone } 4 .\end{array}$ \\
\hline HK2_5 & .73 & .10 & 5.12 & $\mathrm{ft} / \mathrm{d}$ & -- & Yes & $\begin{array}{l}\text { Horizontal hydraulic con- } \\
\text { ductivity layer } 2 \text {, zone } 5 \text {. }\end{array}$ \\
\hline VKA1_1 & $4.18 \times 10^{-4}$ & $3.45 \times 10^{-7}$ & .507 & $\mathrm{ft} / \mathrm{d}$ & -- & Yes & $\begin{array}{l}\text { Vertical hydraulic conduc- } \\
\text { tivity layer } 1 .\end{array}$ \\
\hline VKA2_1 & $8.77 \times 10^{-5}$ & -- & -- & $\mathrm{ft} / \mathrm{d}$ & VKA1_1 & Yes & $\begin{array}{l}\text { Vertical hydraulic conduc- } \\
\text { tivity layer } 2, \text { zone } 1 .\end{array}$ \\
\hline VKA2_2 & 3.66 & -- & -- & $\mathrm{ft} / \mathrm{d}$ & VKA1_1 & Yes & $\begin{array}{l}\text { Vertical hydraulic conduc- } \\
\text { tivity layer } 2 \text {, zone } 2 \text {. }\end{array}$ \\
\hline VKA2_3 & $9.18 \times 10^{-3}$ & -- & -- & $\mathrm{ft} / \mathrm{d}$ & VKA1_1 & Yes & $\begin{array}{l}\text { Vertical hydraulic conduc- } \\
\text { tivity layer } 2 \text {, zone } 3 \text {. }\end{array}$ \\
\hline VKA2_4 & .101 & -- & -- & $\mathrm{ft} / \mathrm{d}$ & VKA1_1 & Yes & $\begin{array}{l}\text { Vertical hydraulic conduc- } \\
\text { tivity layer } 2 \text {, zone } 4 \text {. }\end{array}$ \\
\hline VKA2_5 & $1.32 \times 10^{-2}$ & -- & -- & $\mathrm{ft} / \mathrm{d}$ & VKA1_1 & Yes & $\begin{array}{l}\text { Vertical hydraulic conduc- } \\
\text { tivity layer } 2 \text {, zone } 5 \text {. }\end{array}$ \\
\hline RECH1 & 2.91 & 2.80 & 3.03 & $\mathrm{in} / \mathrm{yr}$ & -- & No & Recharge layer 1. \\
\hline $\mathrm{RECH} 2$ & 1.45 & -- & -- & $\mathrm{in} / \mathrm{yr}$ & RECH1 & No & Recharge layer 2. \\
\hline EVTR1 & 53.02 & 48.71 & 57.70 & $\mathrm{in} / \mathrm{yr}$ & -- & No & $\begin{array}{l}\text { Maximum evapotranspira- } \\
\text { tion rate. }\end{array}$ \\
\hline L_WHITE & $8.64 \times 10^{3}$ & $1.79 \times 10^{3}$ & $4.16 \times 10^{4}$ & $\mathrm{ft}^{2} / \mathrm{d}$ & -- & Yes & Riverbed conductance. \\
\hline KEYA_PAHA & $4.72 \times 10^{3}$ & 22.0 & $1.01 \times 10^{6}$ & $\mathrm{ft}^{2} / \mathrm{d}$ & -- & Yes & Riverbed conductance. \\
\hline CUTMEAT & $5.56 \times 10^{2}$ & -- & -- & $\mathrm{ft}^{2} / \mathrm{d}$ & L_WHITE & Yes & Riverbed conductance. \\
\hline MDUZA & $4.01 \times 10^{3}$ & -- & -- & $\mathrm{ft}^{2} / \mathrm{d}$ & L_WHITE & Yes & Riverbed conductance. \\
\hline BLACKPIPE & $1.44 \times 10^{2}$ & -- & -- & $\mathrm{ft}^{2} / \mathrm{d}$ & L_WHITE & Yes & Riverbed conductance. \\
\hline SAND & $4.72 \times 10^{3}$ & -- & -- & $\mathrm{ft}^{2} / \mathrm{d}$ & KEYA_PAHA & Yes & Riverbed conductance. \\
\hline L_WHITE_SP & $1.00 \times 10^{4}$ & $2.17 \times 10^{2}$ & $4.61 \times 10^{5}$ & $\mathrm{ft}^{2} / \mathrm{d}$ & -- & Yes & Spring conductance. \\
\hline BLACKP_SP & $9.80 \times 10^{2}$ & -- & -- & $\mathrm{ft}^{2} / \mathrm{d}$ & WT_SP & Yes & Spring conductance. \\
\hline LW1D_SP & $9.75 \times 10^{2}$ & -- & -- & $\mathrm{ft}^{2} / \mathrm{d}$ & WT_SP & Yes & Spring conductance. \\
\hline LW2D_SP & $1.00 \times 10^{3}$ & -- & -- & $\mathrm{ft}^{2} / \mathrm{d}$ & WT_SP & Yes & Spring conductance. \\
\hline LW3D_SP & $1.00 \times 10^{3}$ & -- & -- & $\mathrm{ft}^{2} / \mathrm{d}$ & WT_SP & Yes & Spring conductance. \\
\hline WT_SP & $1.28 \times 10^{3}$ & 1.14 & $1.45 \times 10^{6}$ & $\mathrm{ft}^{2} / \mathrm{d}$ & -- & Yes & Spring conductance. \\
\hline OAK_SP & $9.80 \times 10^{2}$ & -- & -- & $\mathrm{ft}^{2} / \mathrm{d}$ & WT_SP & Yes & Spring conductance. \\
\hline
\end{tabular}


Table 11. Water budget for steady-state simulation compared with the water budget from Long and others (2003).

[ $\mathrm{ft}^{3} / \mathrm{s}$, cubic feet per second; $\%$, percent]

\begin{tabular}{|c|c|c|}
\hline & \multicolumn{2}{|c|}{ Flow rate $\left(\mathrm{ft}^{3} / \mathrm{s}\right)$} \\
\hline & 2003 model $^{\mathrm{a}}$ & $\begin{array}{l}\text { Revised model } \\
\text { (this report) }\end{array}$ \\
\hline \multicolumn{3}{|c|}{ Inflows } \\
\hline Storage & 0.5 & 0.2 \\
\hline Constant-head boundary & 17.9 & 12.5 \\
\hline River leakage & 2.1 & 8.1 \\
\hline Recharge & 266.2 & 255.4 \\
\hline Total inflows & 286.7 & 276.1 \\
\hline \multicolumn{3}{|c|}{ Outflows } \\
\hline Storage & 0.7 & 0.2 \\
\hline Constant-head boundary & 13.2 & 9.9 \\
\hline Well withdrawals & 11.6 & 11.6 \\
\hline $\begin{array}{l}\text { Springs along northern bound- } \\
\text { ary }\end{array}$ & .5 & 1.1 \\
\hline River leakage $^{\mathrm{b}}$ & 78.0 & 81.4 \\
\hline Evapotranspiration & 183.9 & 171.3 \\
\hline Total outflows & 287.9 & 275.5 \\
\hline \multicolumn{3}{|c|}{ Summary } \\
\hline Inflows minus outflows & -1.2 & 0.6 \\
\hline Budget descrepancy & $-.4 \%$ & $.2 \%$ \\
\hline
\end{tabular}

for the steady-state simulation was $12.5 \mathrm{ft}^{3} / \mathrm{s}$. Discharge rates for the steady-state simulation were $171.3 \mathrm{ft}^{3} / \mathrm{s}$ for evapotranspiration, $74.4 \mathrm{ft}^{3} / \mathrm{s}$ for net outflow (outflow minus inflow) to streams and springs, $11.6 \mathrm{ft}^{3} / \mathrm{s}$ for well withdrawals, and $9.9 \mathrm{ft}^{3} / \mathrm{s}$ as outflow from model constant-head boundaries.

A sensitivity analysis was used to examine the response of the steady-state model to changes in parameter values. During each simulation when a parameter was being tested, the other parameters remained at the steady-state calibrated value. The fractional changes in the objective function values for a 5-percent change in parameter values are shown in figure 19. The model was most sensitive to HK2_3, RECH1, and RECH2 followed by HK1_3, VKA1_1, and EVTR1. In terms of parameter classes, the model was most sensitive to recharge and maximum evapotranspiration rate and least sensitive to riverbed and spring conductances (fig. 20).

This sensitivity analysis was useful for quantifying the sensitivity of each parameter with respect to all other parameters. The information gained from this analysis is limited, however, because it does not take into account parameter sensitivities as they covary with other parameters. Confidence intervals on parameter estimates calculated by PEST take into account these sensitivities as parameters covary (Doherty, 2004) and thus provide an assessment of confidence in the values estimated. Also, high correlation between two parameters indicates parameter sets that when varied in a complementary manner have little effect on the objective function value (Doherty, 2004), and thus highly correlated parameters are not desirable. A matrix of parameter correlation coefficients for the independent parameters shows no highly correlated parameter pairs (correlation coefficient greater than 0.95) with the highest correlation coefficient of 0.64 occurring between RECH1 and VKA1_1 (table 12).

A comparison of estimated $K$ values shows differences between calibration of the model described by Long and others (2003) and the revised model described in this report (table 13). The percent deviation from Long and others (2003) ranged from 0 for several values to more than 900 for one of the vertical $K$ values (table 13). Estimated values with the largest percent change were associated with the small parameter sensitivities (fig. 19), and thus, changes in these parameter values resulted in only minor changes to model outcome. These and other revisions to the model resulted in minor changes to the steady-state water budget (table 11).

\section{Transient Simulation}

All parameter estimates from the steady-state calibration except for the time-varying parameters recharge and maximum evapotranspiration rate were applied to the transient model (table 10). Estimated recharge and maximum evapotranspiration rates for the transient model are shown in tables 6 and 2 , respectively. Estimated recharge for the Arikaree aquifer was one-half that of the Ogallala aquifer (table 6). Additional adjustments to model parameters were not necessary to achieve acceptable calibration. Calibration criteria for the transient simulation consisted of approximately reproducing the general temporal trends of the hydrographs for the 44 observation wells. No attempt was made to calibrate the transient simulation to match hydraulic heads in the observation wells closer than that required for the steady-state simulation $( \pm 50 \mathrm{ft})$. Therefore, a difference of as much as $50 \mathrm{ft}$ between the observed and simulated well hydrographs was acceptable if the general trends matched reasonably well.

In most cases, the simulated water levels were within $40 \mathrm{ft}$ of observed values, and the general trends in simulated and observed hydraulic heads matched reasonably well with some exceptions (figs. 21 and 22). In some cases, the simulated hydrograph had an upward trend when the observed hydrograph had a downward trend, or the opposite. In other cases, the trends were consistent. Although the simulated hydrograph trends were not always consistent with those observed, the overall variability of simulated hydrographs generally was consistent with the variability of the observed hydrographs, and it is this variability that is of most concern for purposes of simulating the effects of drought or increased pumping. Measured water levels for well RST-19 (fig. 22) declined by about $30 \mathrm{ft}$ in less than 1 year. Because this is unusual for the Ogallala aquifer and is the only well where such a large decline occurred, the data may be in error. 
Table 12. Parameter correlation matrix showing correlation coefficients for all parameter pair combinations. (Parameter names defined in table 10). [--, not included because of redundancy $]$

\begin{tabular}{|c|c|c|c|c|c|c|c|c|c|c|c|c|c|c|c|}
\hline $\begin{array}{l}\text { Parameter } \\
\text { name }\end{array}$ & L_WHITE_SP & WT_SP & HK1_1 & HK1_2 & HK1_3 & HK1_5 & HK2_1 & HK2_2 & HK2_3 & HK2_5 & VKA1_1 & RECH1 & EVTR1 & L_WHITE & KEYA_PAHA \\
\hline L_WHITE_SP & 1.00 & -- & -- & -- & -- & -- & -- & -- & -- & -- & -- & -- & -- & -- & -- \\
\hline WT_SP & -.52 & 1.00 & -- & -- & -- & -- & -- & -- & -- & -- & -- & -- & -- & -- & -- \\
\hline HK1_1 & -.07 & .02 & 1.00 & -- & -- & -- & -- & -- & -- & -- & -- & -- & -- & -- & -- \\
\hline HK1_2 & -.04 & .03 & 0 & 1.00 & -- & -- & -- & -- & -- & -- & -- & -- & -- & -- & -- \\
\hline HK1_3 & -.08 & .02 & .10 & .18 & 1.00 & -- & -- & -- & -- & -- & -- & -- & -- & -- & -- \\
\hline HK1_5 & -.02 & -.01 & .04 & .20 & .32 & 1.00 & -- & -- & -- & -- & -- & -- & -- & -- & -- \\
\hline HK2_1 & .04 & -.09 & -.10 & -.01 & .13 & .06 & 1.00 & -- & -- & -- & -- & -- & -- & -- & -- \\
\hline HK2_2 & -.01 & .02 & .04 & .02 & .23 & .18 & .07 & 1.00 & -- & -- & -- & -- & -- & -- & -- \\
\hline HK2_3 & -.35 & .26 & .04 & 0 & -.07 & .01 & -.01 & .01 & 1.00 & -- & -- & -- & -- & -- & -- \\
\hline HK2_5 & .01 & .11 & .04 & .01 & .10 & -.14 & .06 & .05 & .01 & 1.00 & -- & -- & -- & -- & -- \\
\hline VKA1_1 & -.07 & .12 & -.19 & .14 & -.29 & -.03 & -.28 & -.12 & -.07 & -.19 & 1.00 & -- & -- & -- & -- \\
\hline RECH1 & -.10 & .10 & -.07 & .38 & .26 & .40 & -.11 & .18 & -.03 & -.06 & .64 & 1.00 & -- & -- & -- \\
\hline EVTR1 & -.02 & .01 & 0 & .06 & .06 & .08 & 0 & .07 & 0 & .01 & .02 & .14 & 1.00 & -- & -- \\
\hline L_WHITE & .14 & .18 & .03 & -.02 & .01 & -.01 & -.13 & .01 & .01 & .01 & -.10 & -.07 & -.01 & 1.00 & -- \\
\hline KEYA_PAHA & .01 & -.77 & .02 & -.02 & .02 & .03 & .02 & -.03 & .01 & -.15 & -.08 & -.06 & 0 & .01 & 1.00 \\
\hline
\end{tabular}




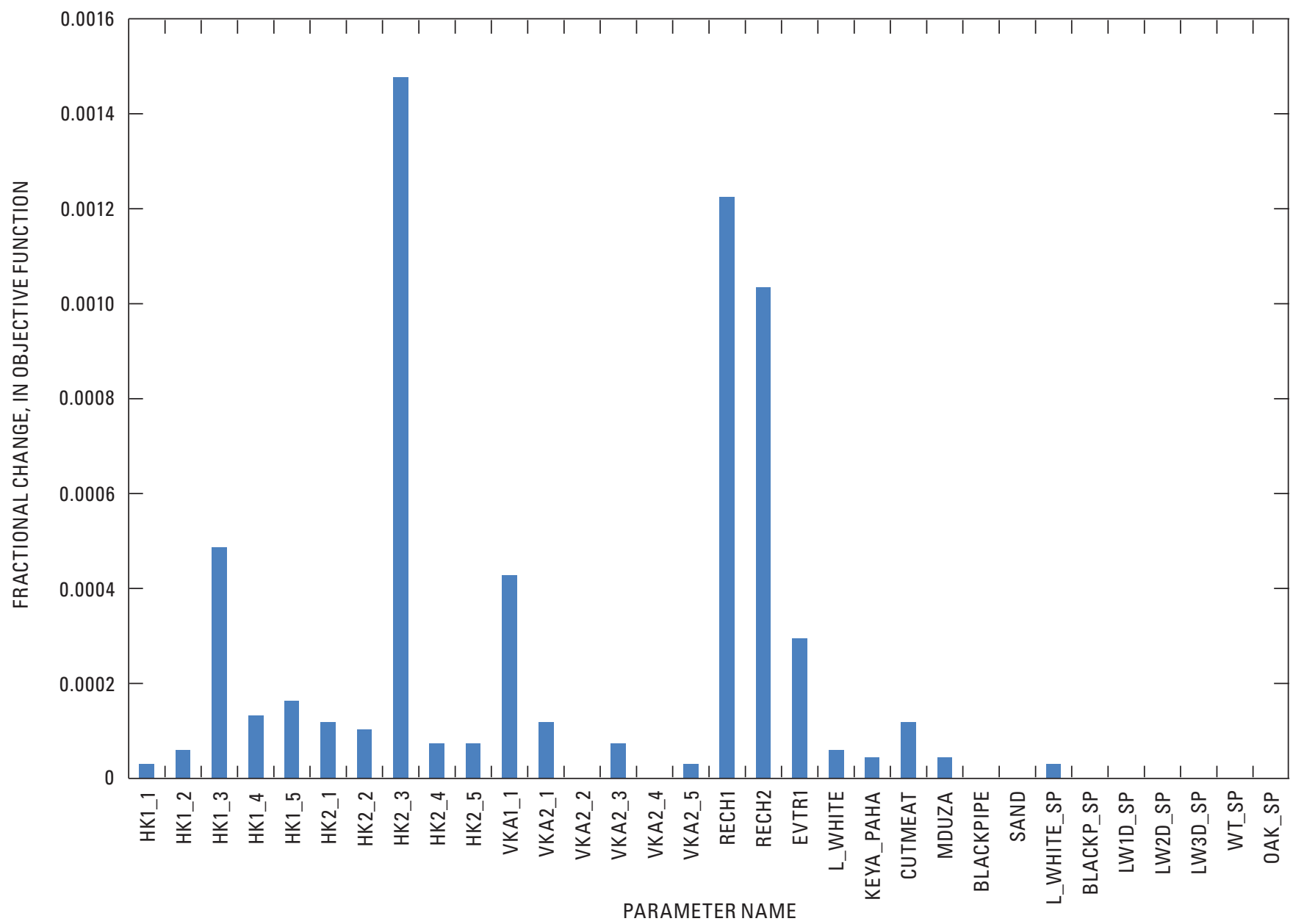

Figure 19. Relative parameter sensitivities as a fractional change in the objective function (sum of the squared weighted residuals) resulting from a 5-percent change in parameter values. (Parameter names defined in table 10).

\section{Simulation of Potential Future Scenarios}

Model simulations were conducted to assess groundwater responses to potential future drought and increases in well withdrawals. A synthetic drought simulation recharge record was created that has similar variability to that of the original estimated record (table 6), except that on average, the synthetic drought record was approximately equal to the 30th-percentile recharge rates for each model season of the original record. Random variability was added to this 30th-percentile recharge rate for each season with a maximum possible variability that was similar to that of the original estimated record for each respective season. This resulted in a mean drought recharge rate for the overall record of $1.87 \mathrm{in} / \mathrm{yr}$ for the Ogallala aquifer, or 64 percent of the original average recharge rate of $3.91 \mathrm{in} / \mathrm{yr}$. The simulation was executed as a 30 -year transient simulation with the first 10 years having the same recharge as in the original record. The synthetic drought record was used for last 20 years of the simulation. Hydrographs of the simulated observation wells plotted with results of the non-drought simulation show the effects of this drought scenario for selected sites (fig. 23). The simulated maximum decline in water levels for the 44 observation wells as a result of the drought simulation ranged from about 1 to $16 \mathrm{ft}$, and about 50 percent of the wells had declines of 8 to $16 \mathrm{ft}$.

The differences in hydraulic-head values between results of the calibrated model and the drought scenario at the end of the 30 -year simulation ranged from 0 to $39 \mathrm{ft}$ for the Ogallala aquifer. The largest differences were in the northwestern part of the model area followed by the center of the model area where many irrigation wells are located. The shift in position of potentiometric contours from those of the calibrated model to those of the drought scenario indicates the differences (fig. 24).

To assess the effects of potential increases in pumping, well withdrawal rates were increased by 50 percent from those listed in table 4 for the last 20 years of record. The first 10 years of record were unchanged from table 4 (fig. 25). The simulated maximum decline in water levels for the 44 observation wells as a result of simulated pumping increases ranged from less than 0.5 to $5 \mathrm{ft}$. The differences in hydraulic-head values between results of the calibrated model and the increased scenario of pumping at the end of the 30 -year simulation ranged from 0 to $13 \mathrm{ft}$ for the Ogallala 


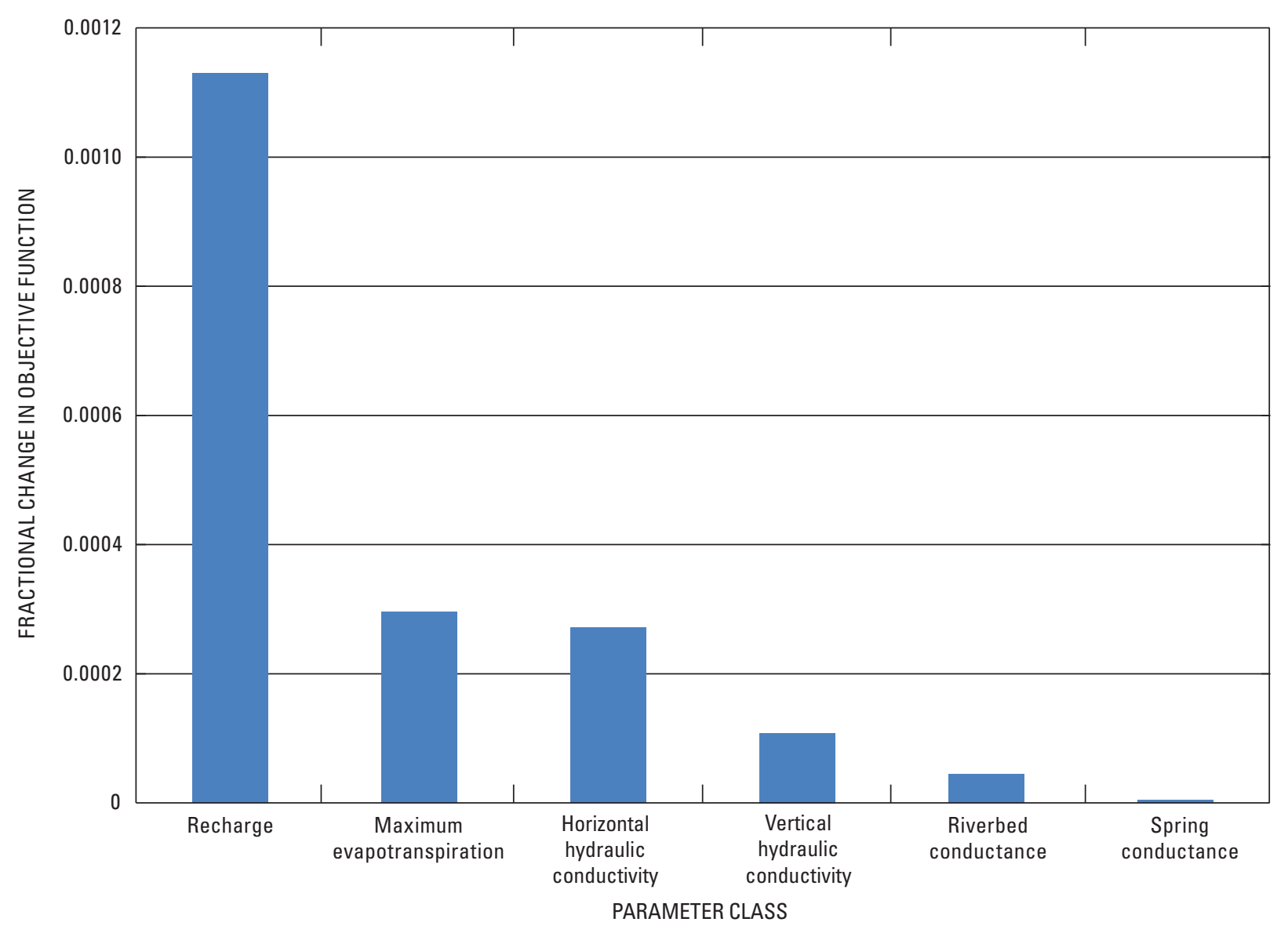

Figure 20. Relative sensitivities of parameter classes as a percent change in the objective function (sum of the squared weighted residuals) resulting from a 5-percent change in parameter values. Sensitivities were calculated as averages of those in figure 19.

aquifer, with the largest differences in the center of the model area where many irrigation wells are located. The shift in position of potentiometric contours from those of the calibrated model to those of the drought scenario are shown in figure 26; the shift generally is only evident in the center of the model area where the largest groundwater withdrawals occur.

\section{Model Limitations}

For purposes and objectives of this study, the numerical model adequately simulates flow in the Ogallala and Arikaree aquifers in the study area. However, water managers should be aware of the model's limitations. There are uncertainties in model input parameters, most importantly recharge, evapotranspiration, and horizontal and vertical hydraulic conductivity. Although these parameters had a large influence on model results, extensive field data with respect to these were not available. The objective function possibly could have been reduced more by breaking down further the spatial discretization of some parameters, such as hydraulic conductivity or recharge; however, without additional field data, finer discretization was not justifiable. Combinations of parameter values other than those used in this model also might give satisfactory results, and thus, parameter confidence intervals help to quantify the uncertainty in the final set of estimated parameter values. The use of inverse modeling methods resulted in more objective parameter estimates than did previous trial-and-error methods.

This numerical model is suitable as a tool to help understand the flow system, to help confirm that previous estimates of aquifer properties were reasonable, and to estimate aquifer properties in areas without data. The model also is useful to help assess the effects of drought and increases in pumping by simulations of these scenarios, the results of which are not precise but may be considered when making water management decisions. Limitations of the model should be taken into account when applying the model to water management. With additional data, further refinement of the model would be possible, which could improve the accuracy of model prediction of the effects of additional stresses on the system, such as increased withdrawals or drought. 

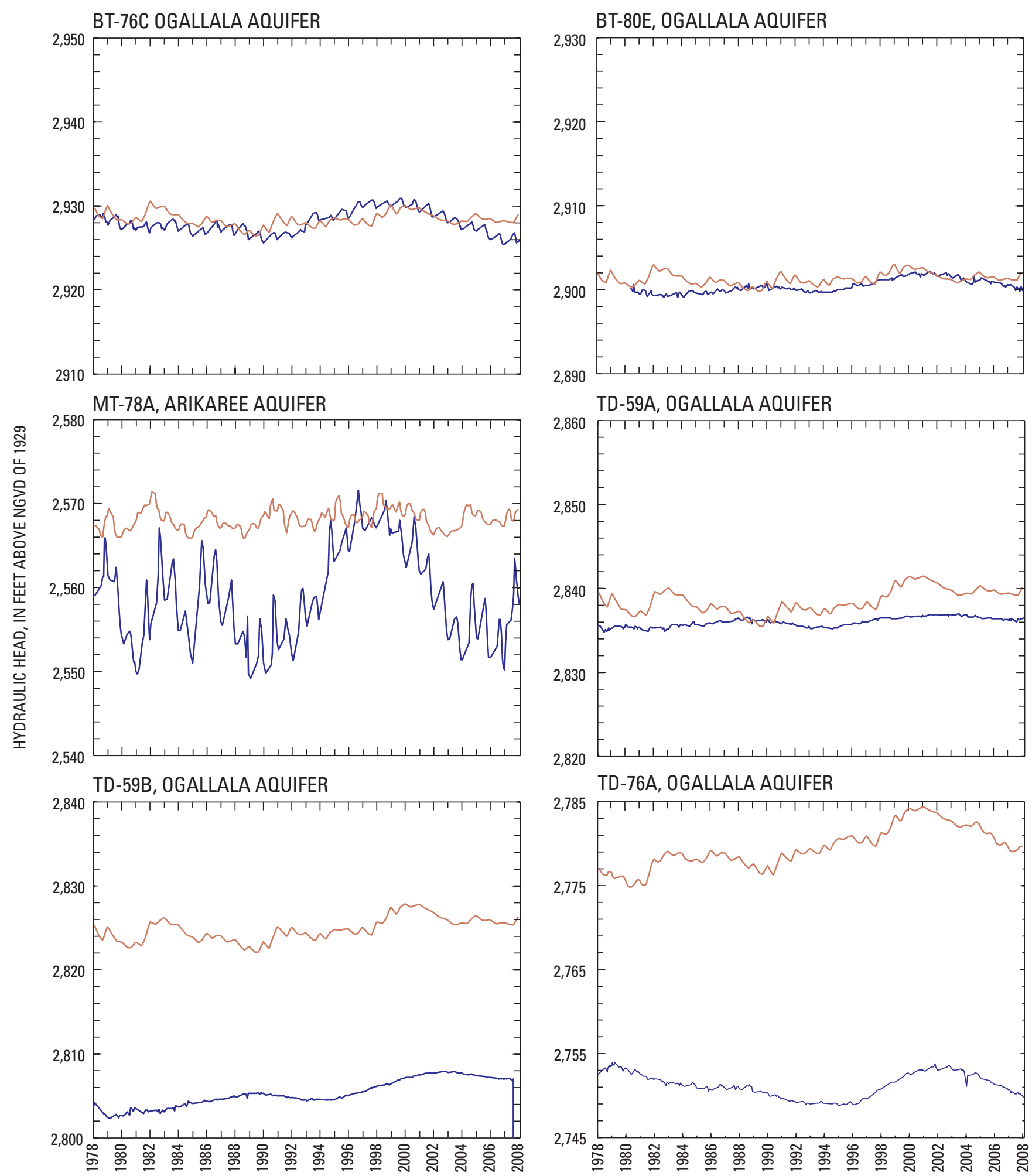

CALENDAR YEAR

\section{EXPLANATION}

Simulated

Observed

Figure 21. Hydrographs showing simulated and observed data for State observation wells for calibrated transient model. 

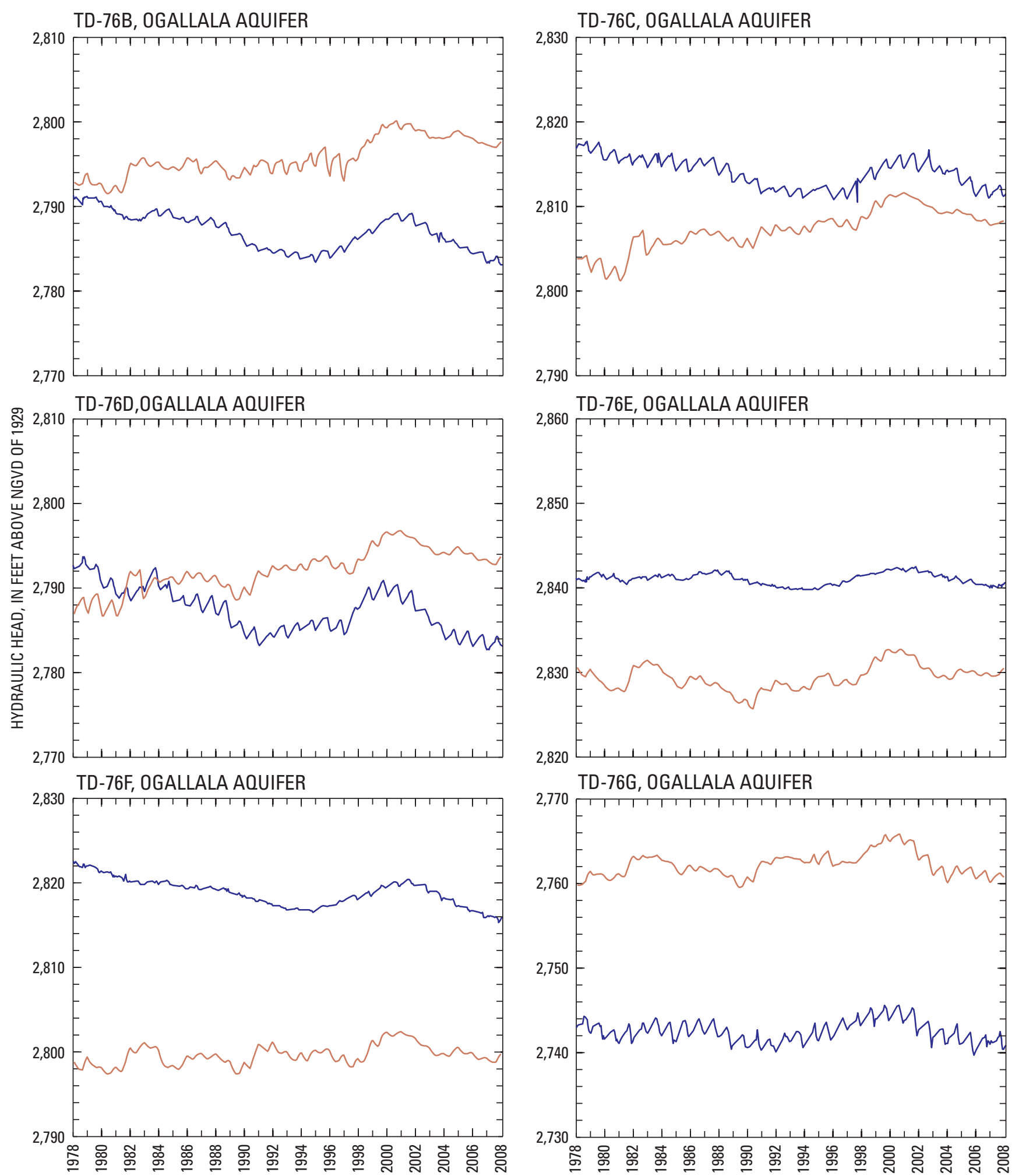

CALENDAR YEAR

\section{EXPLANATION}

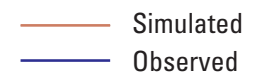

Figure 21. Hydrographs showing simulated and observed data for State observation wells for calibrated transient model.Continued 
TD-76H, OGALLALA AQUIFER
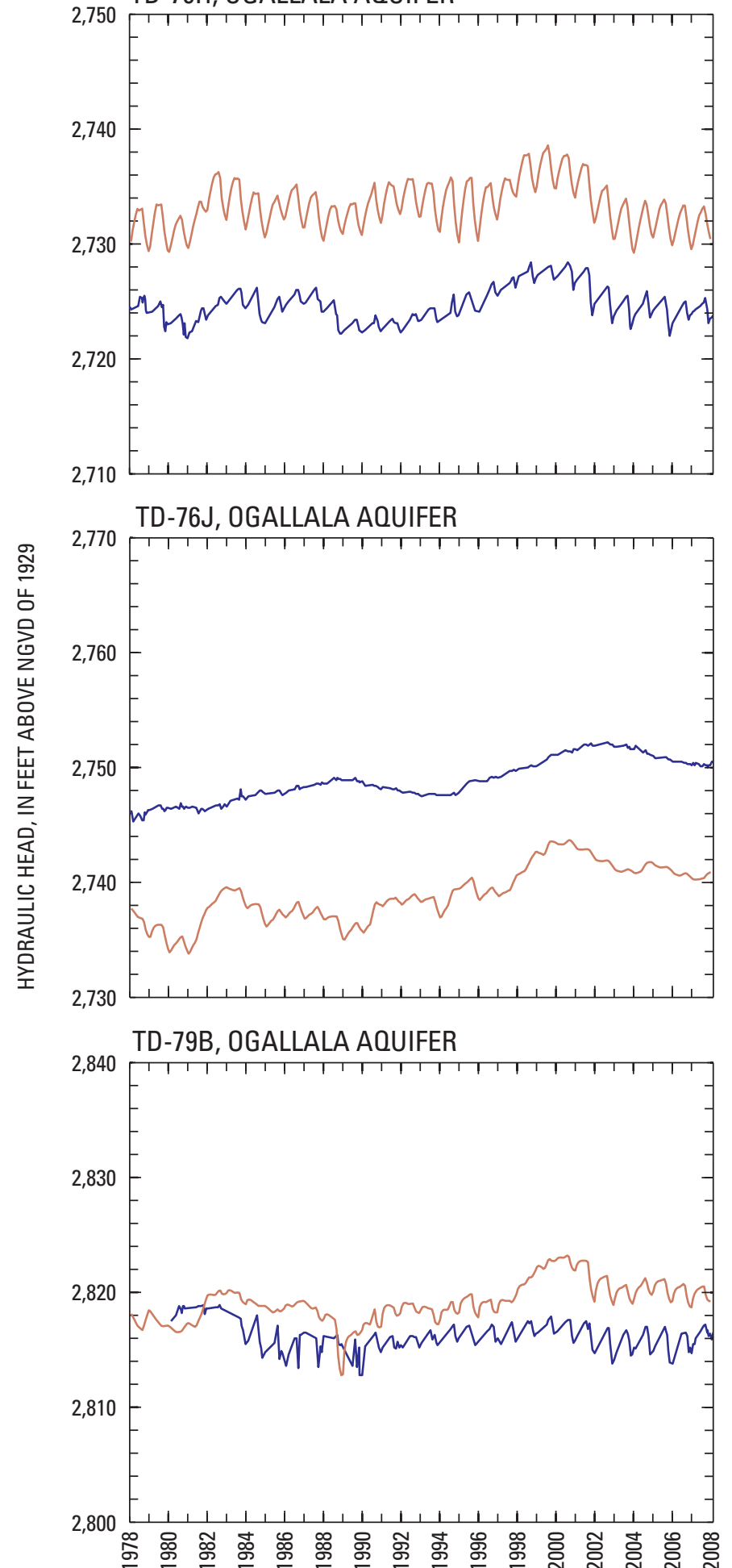

TD-76I, OGALLALA AOUIFER

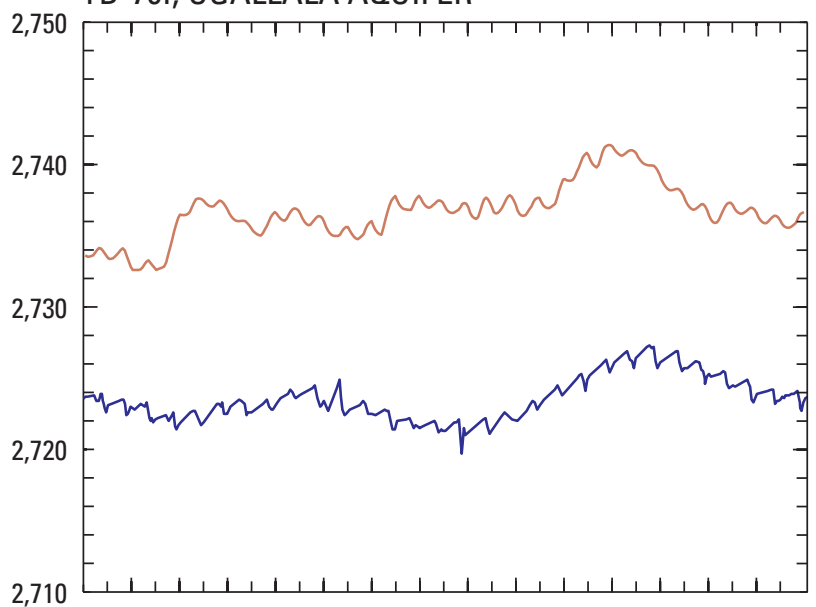

TD-79A, ARIKAREE AQUIFER

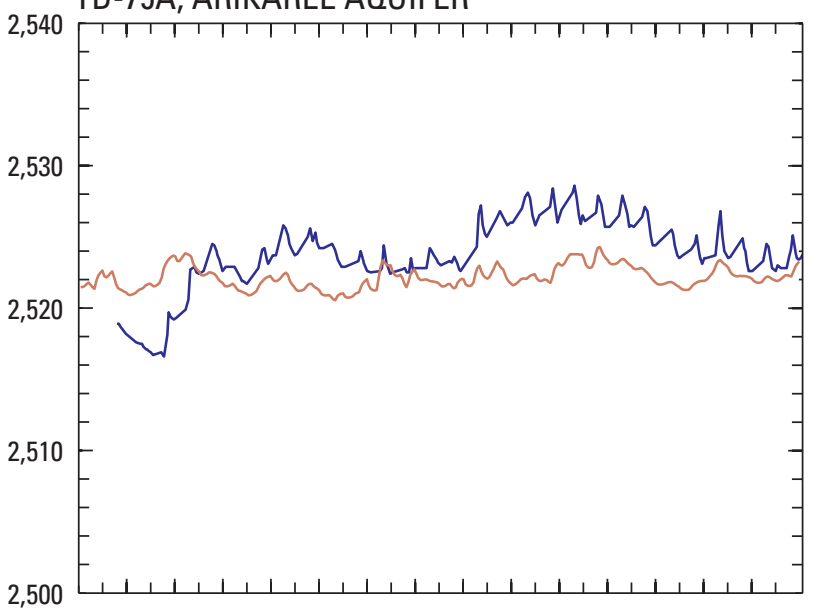

TD-79D, ARIKAREE AOUIFER

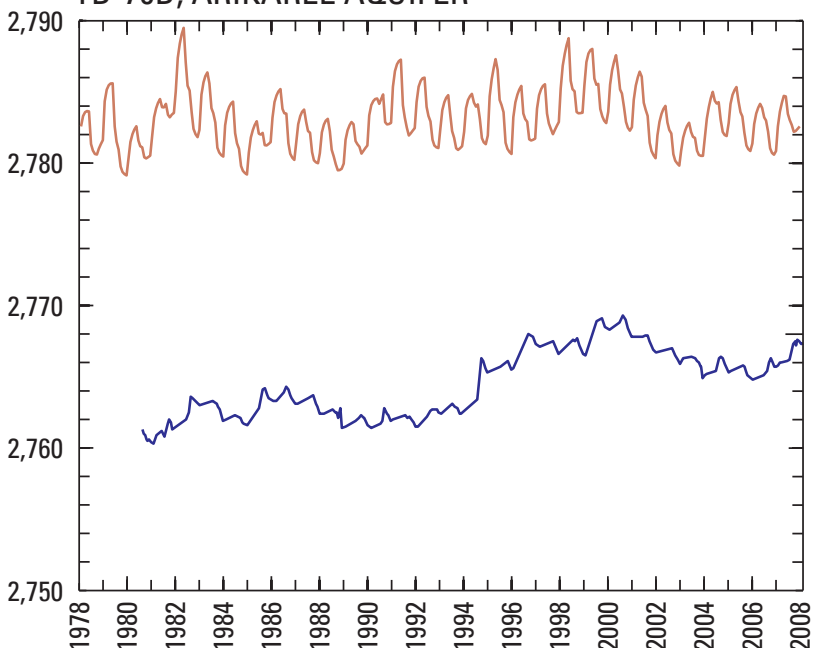

CALENDAR YEAR

\section{EXPLANATION}

Simulated

Observed

Figure 21. Hydrographs showing simulated and observed data for State observation wells for calibrated transient model.Continued 

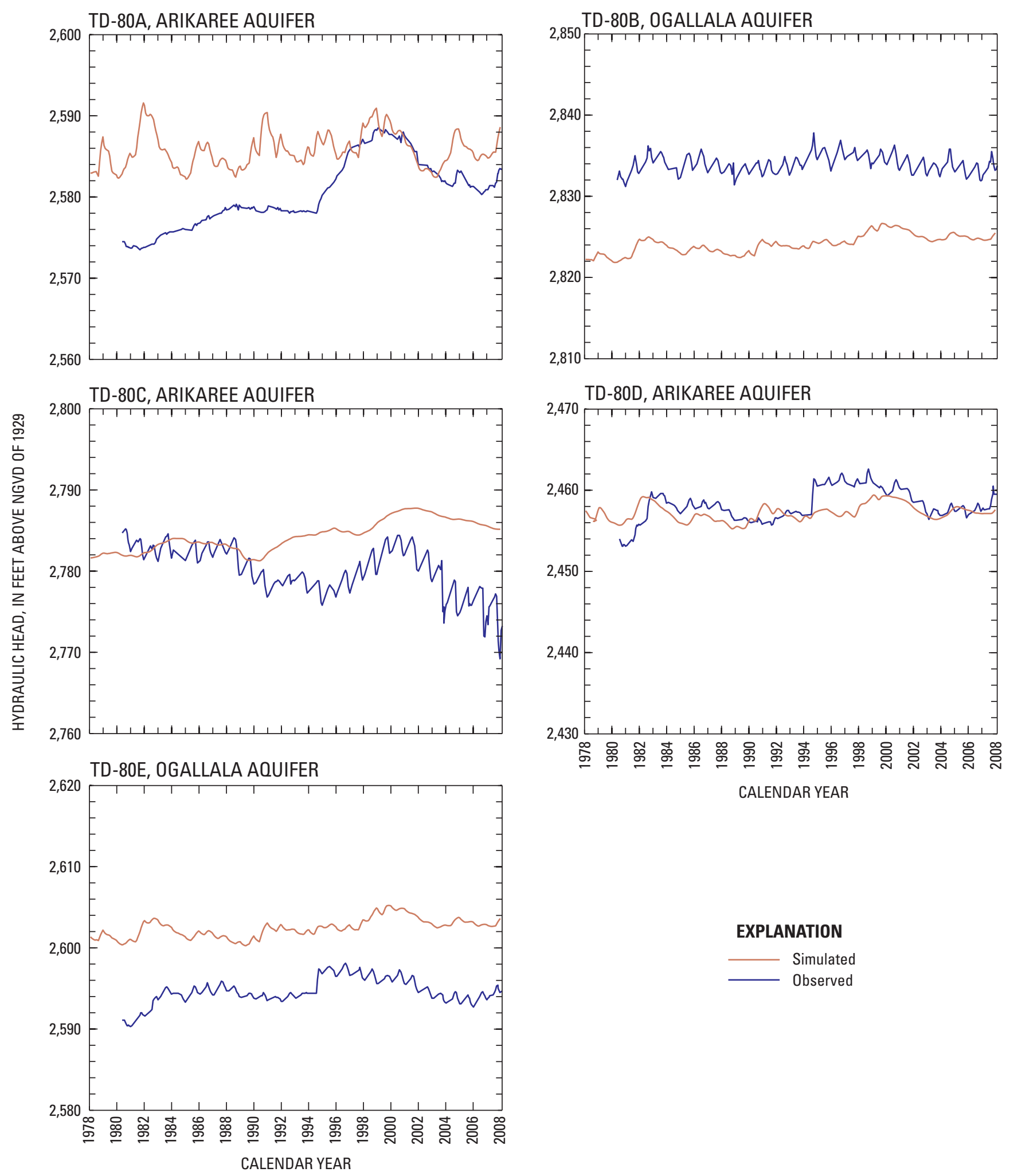

\section{EXPLANATION}

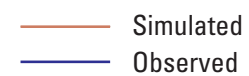

Figure 21. Hydrographs showing simulated and observed data for State observation wells for calibrated transient model.Continued 
Table 13. Comparison of estimated hydraulic conductivity values for the model described by Long and others (2003) and the revised model described in this report.

[--, not applicable]

\begin{tabular}{|c|c|c|c|}
\hline Zone & 2003 model $^{\mathrm{a}}$ & $\begin{array}{c}\text { Revised model } \\
\text { described in this report }\end{array}$ & $\begin{array}{c}\text { Deviation from } 2003 \\
\text { model as a percentage }\end{array}$ \\
\hline \multicolumn{4}{|c|}{ Horizontal hydraulic conductivity layer 1} \\
\hline Zone 1 & -- & 1.3 & -- \\
\hline Zone 1 & 2 & 5.4 & 170 \\
\hline Zone 1 & 20 & 26.8 & 34 \\
\hline Zone 2 & .2 & .2 & 0 \\
\hline Zone 2 & 7.6 & 8.4 & 11 \\
\hline Zone 2 & 23 & 25.1 & 9 \\
\hline Zone 3 & 9 & .4 & -56 \\
\hline Zone 3 & 9.3 & 2.8 & -70 \\
\hline Zone 3 & 46 & 28.1 & -39 \\
\hline Zone 3 & 120 & 84.4 & -30 \\
\hline Zone 4 & 2.5 & 2.5 & 0 \\
\hline Zone 5 & 37 & 13.3 & -64 \\
\hline \multicolumn{4}{|c|}{ Horizontal hydraulic conductivity layer 2} \\
\hline Zone 1 & 5.4 & 3.8 & -30 \\
\hline Zone 2 & 2.3 & 2.2 & -4 \\
\hline Zone 2 & 4.7 & 4.3 & -9 \\
\hline Zone 3 & 1.2 & 1.2 & 0 \\
\hline Zone 3 & 2.4 & 2.4 & 0 \\
\hline Zone 3 & 1.2 & .1 & -92 \\
\hline Zone 4 & .1 & .1 & 0 \\
\hline Zone 5 & 1.3 & 1.1 & -15 \\
\hline \multicolumn{4}{|c|}{ Vertical hydraulic conductivity layer 1} \\
\hline Zone 1 & $6.6 \times 10^{-4}$ & $4.2 \times 10^{-4}$ & -37 \\
\hline \multicolumn{4}{|c|}{ Vertical hydraulic conductivity layer 2} \\
\hline Zone 1 & $8.6 \times 10^{-6}$ & $8.8 \times 10^{-5}$ & 923 \\
\hline Zone 2 & .72 & 3.7 & 414 \\
\hline Zone 3 & $1.8 \times 10^{-3}$ & $9.2 \times 10^{-3}$ & 411 \\
\hline Zone 4 & $2.0 \times 10^{-2}$ & .10 & 400 \\
\hline Zone 5 & $2.6 \times 10^{-3}$ & $1.3 \times 10^{-2}$ & 400 \\
\hline
\end{tabular}



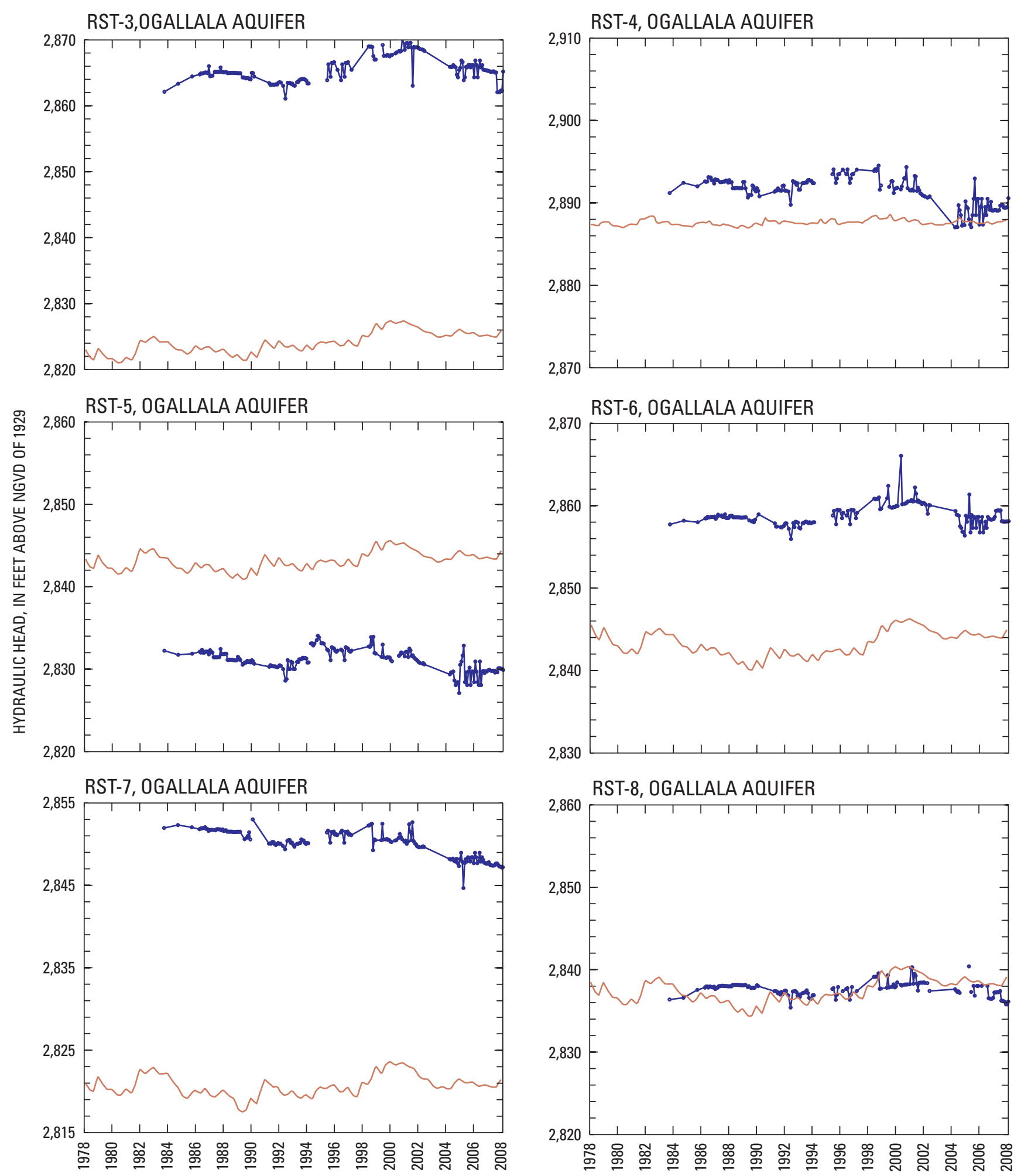

CALENDAR YEAR

\section{EXPLANATION}

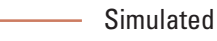

Observed

Figure 22. Hydrographs showing simulated and observed data for Tribal observation wells for calibrated transient model. 

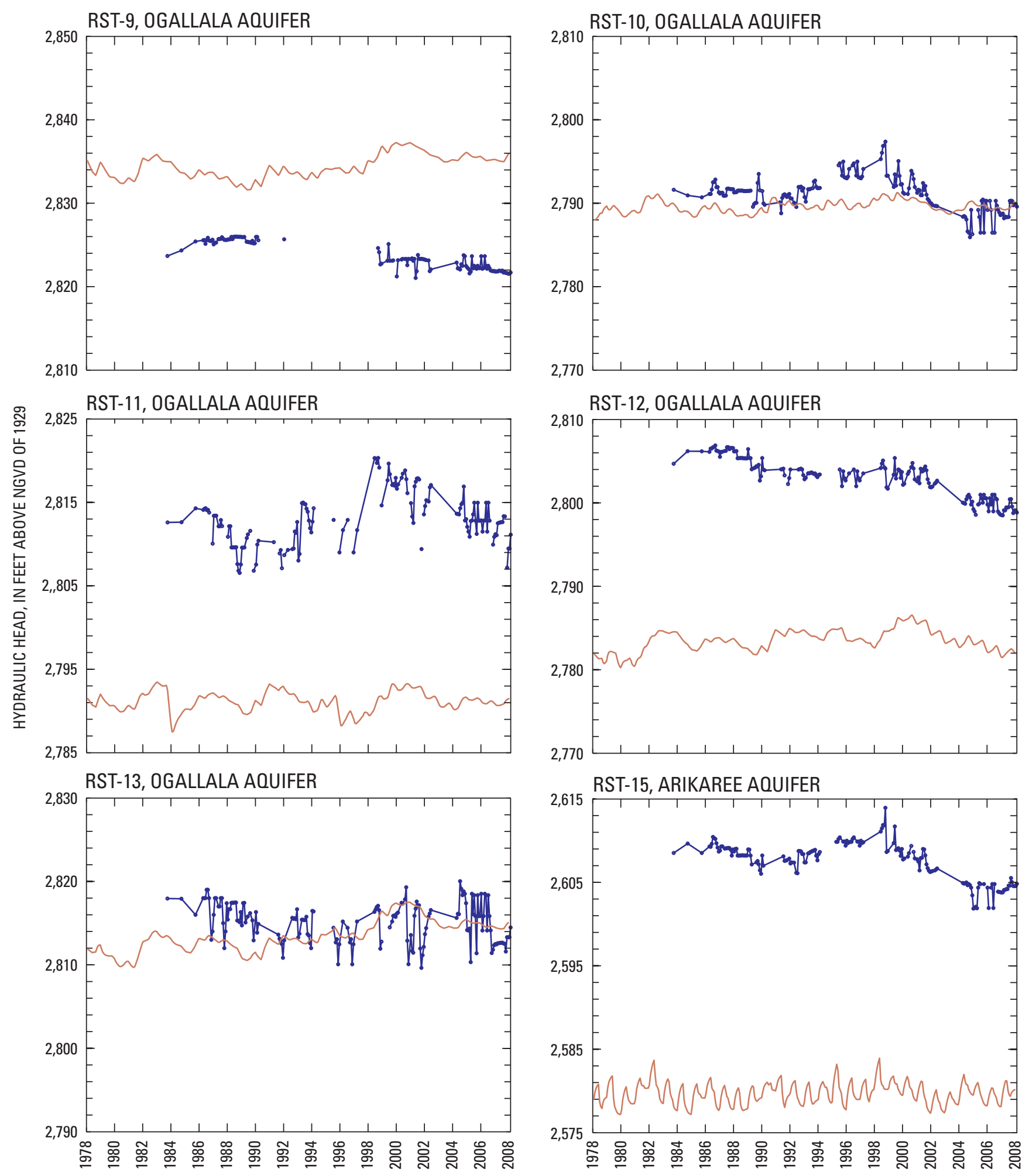

CALENDAR YEAR

\section{EXPLANATION}

Simulated

Observed

Figure 22. Hydrographs showing simulated and observed data for Tribal observation wells for calibrated transient model.Continued 

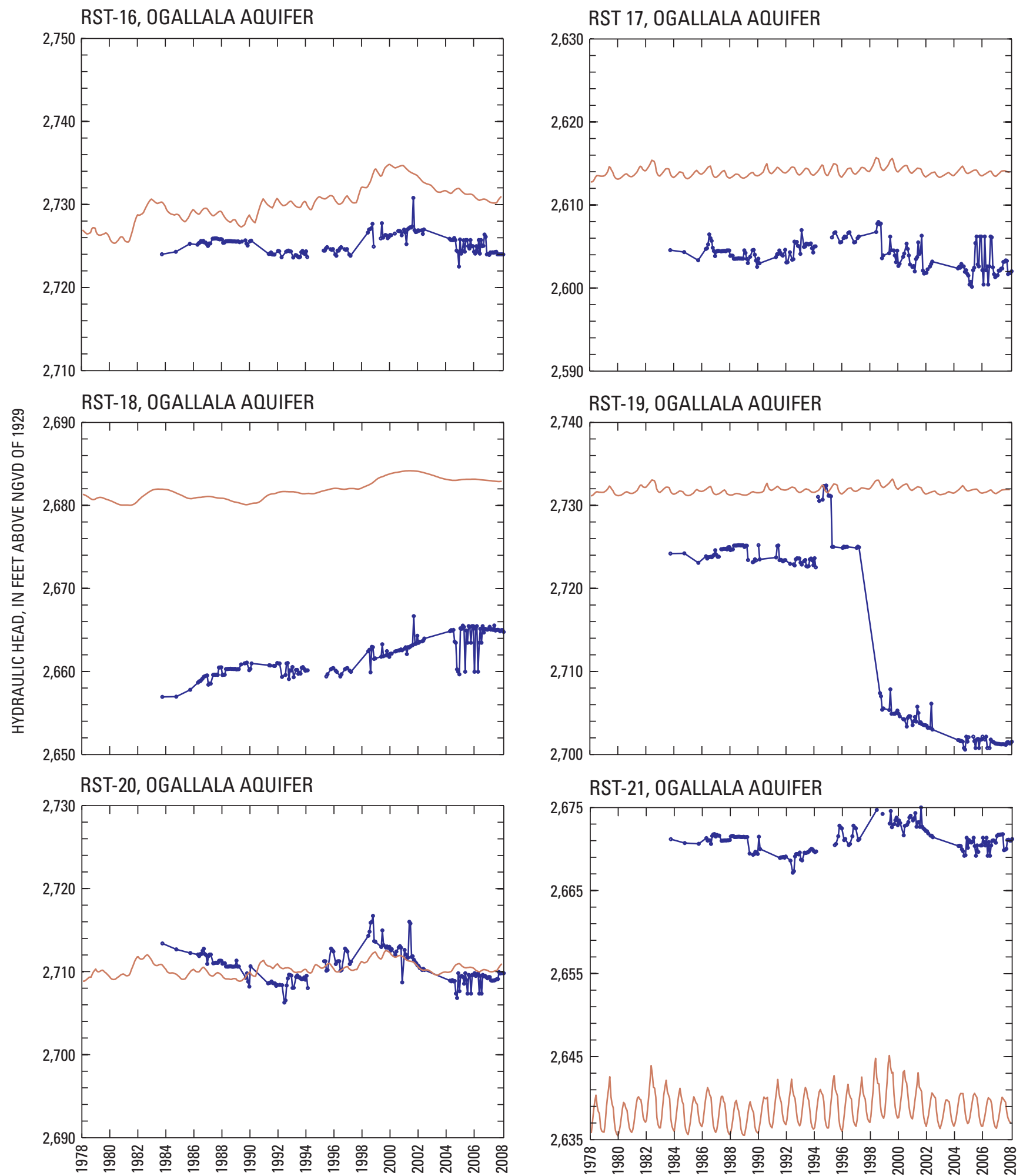

CALENDAR YEAR

\section{EXPLANATION}

Simulated

Ohserved

Figure 22. Hydrographs showing simulated and observed data for Tribal observation wells for calibrated transient model.Continued 


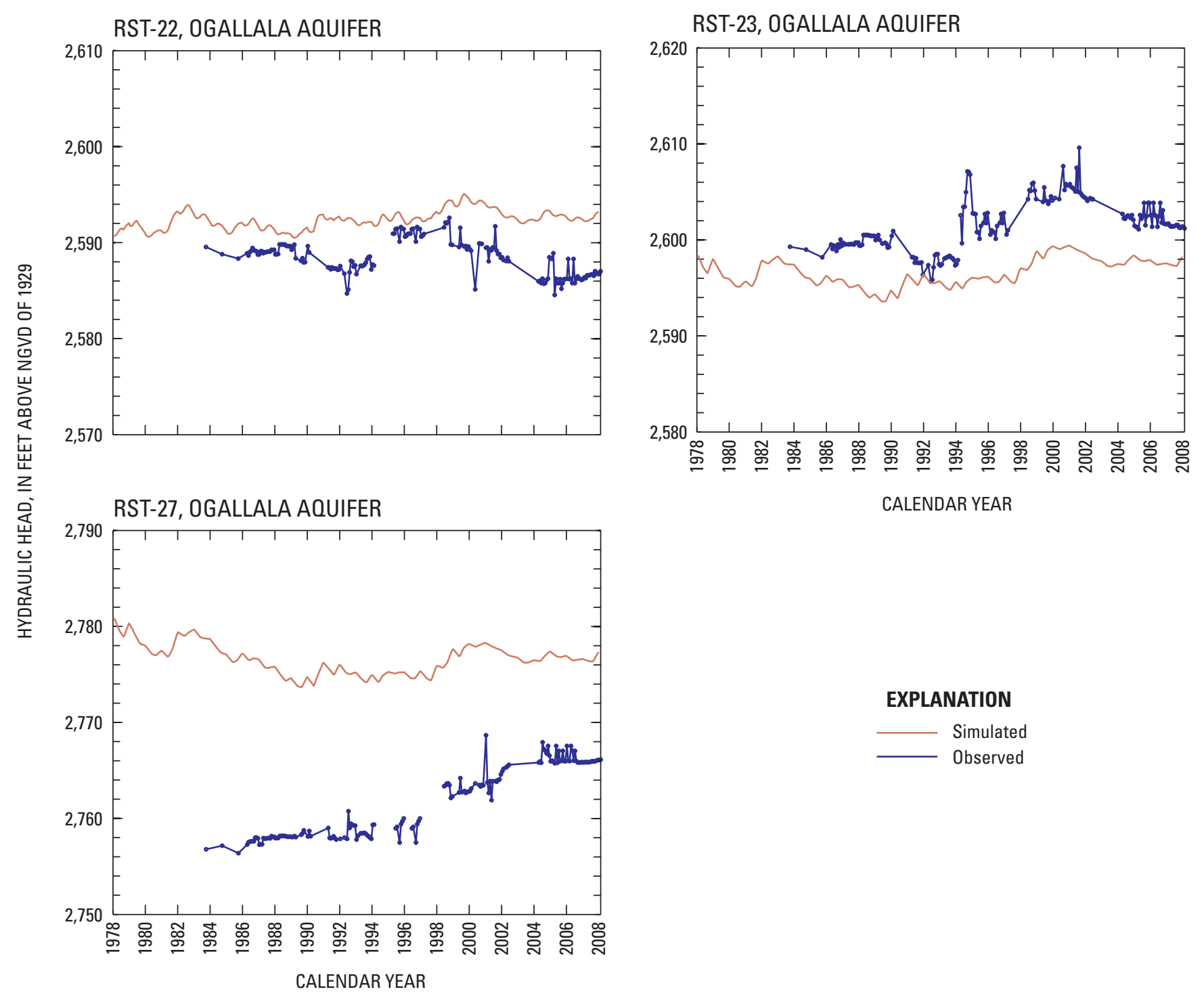

Figure 22. Hydrographs showing simulated and observed data for Tribal observation wells for calibrated transient model.Continued 

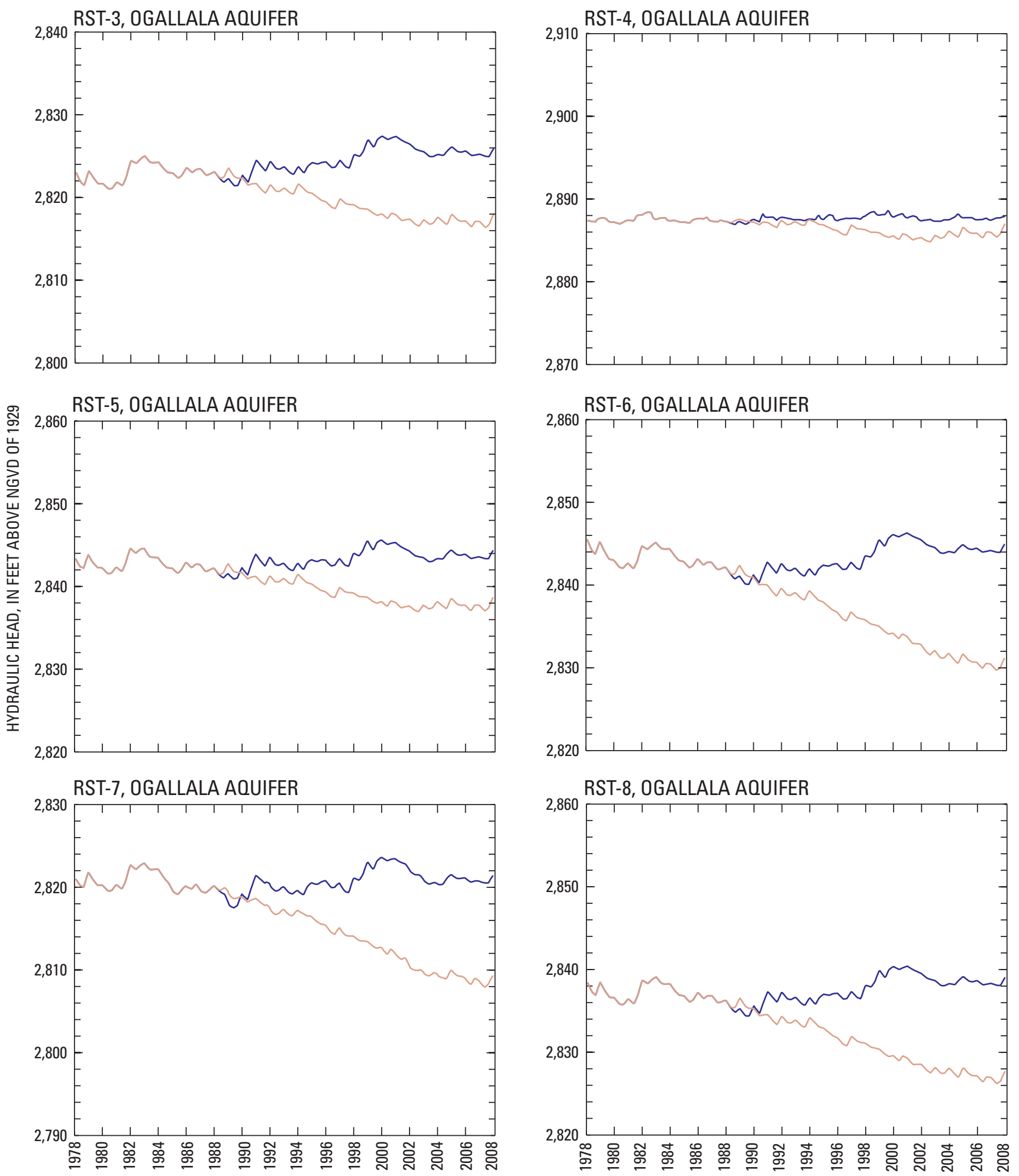

CALENDAR YEAR

\section{EXPLANATION}

Calibrated model

Drought scenario

Figure 23. Hydrographs showing the differences of water levels in wells between results of the calibrated model and the assumed potential drought scenario for the 30 -year simulation period for selected sites for the 0 gallala aquifer. 


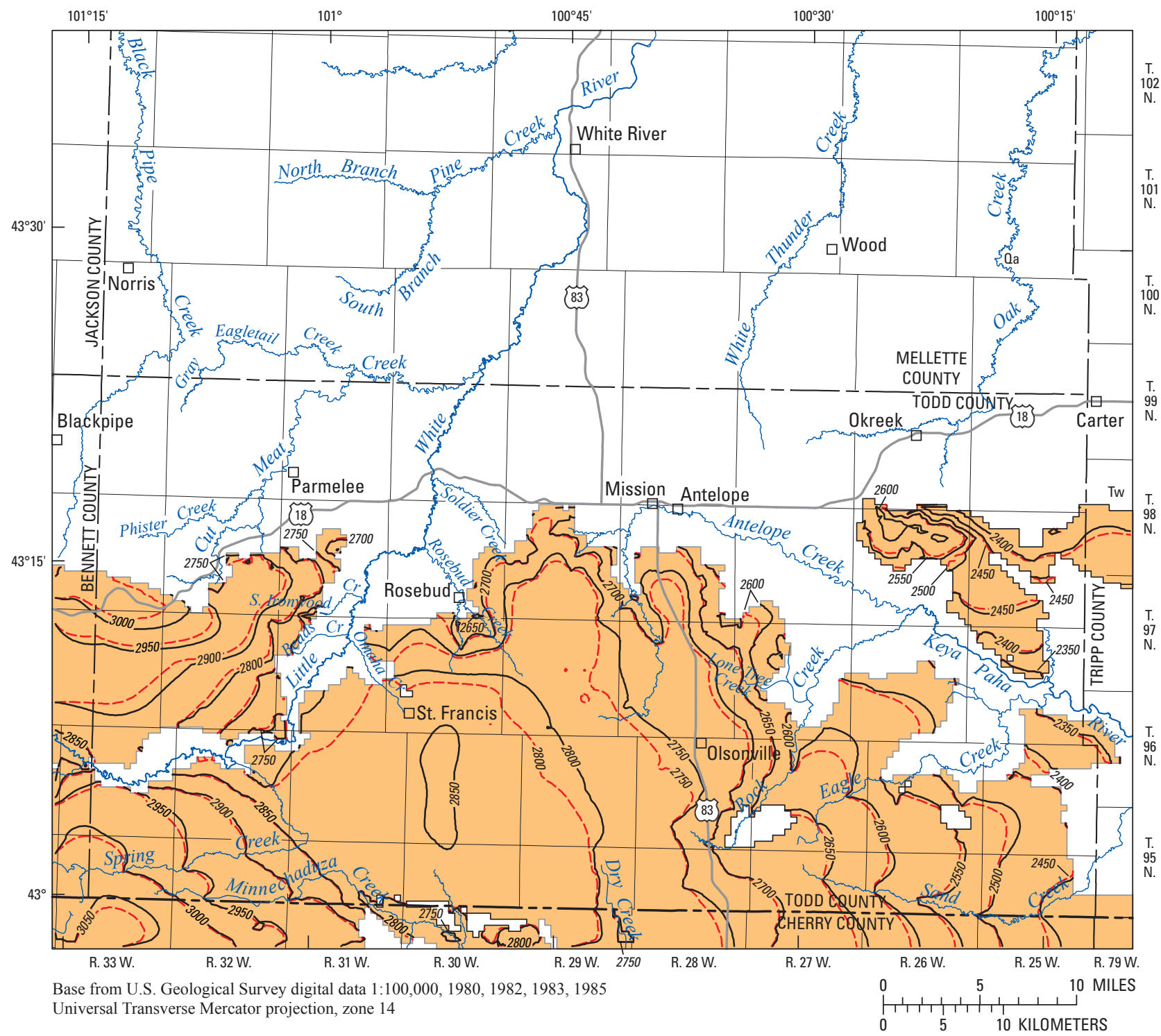

EXPLANATION

Ogallala aquifer active cells

-3550- Simulated potentiometric contour for the calibrated model at the end of the 30-year simulation-Shows average altitude at which water level would have stood in tightly cased wells. Contour interval is 50 feet. Datum is NGVD of 1929

- -3550-- Simulated potentiometric contour for the drought scenario at the end of the 30-year simulationShows average altitude at which water level would have stood in tightly cased wells. Contour interval is 50 feet. Datum is NGVD of 1929

Figure 24. Simulated potentiometric surfaces for the calibrated model and the drought scenario at the end of a 30 -year simulation period for the Ogallala aquifer. 

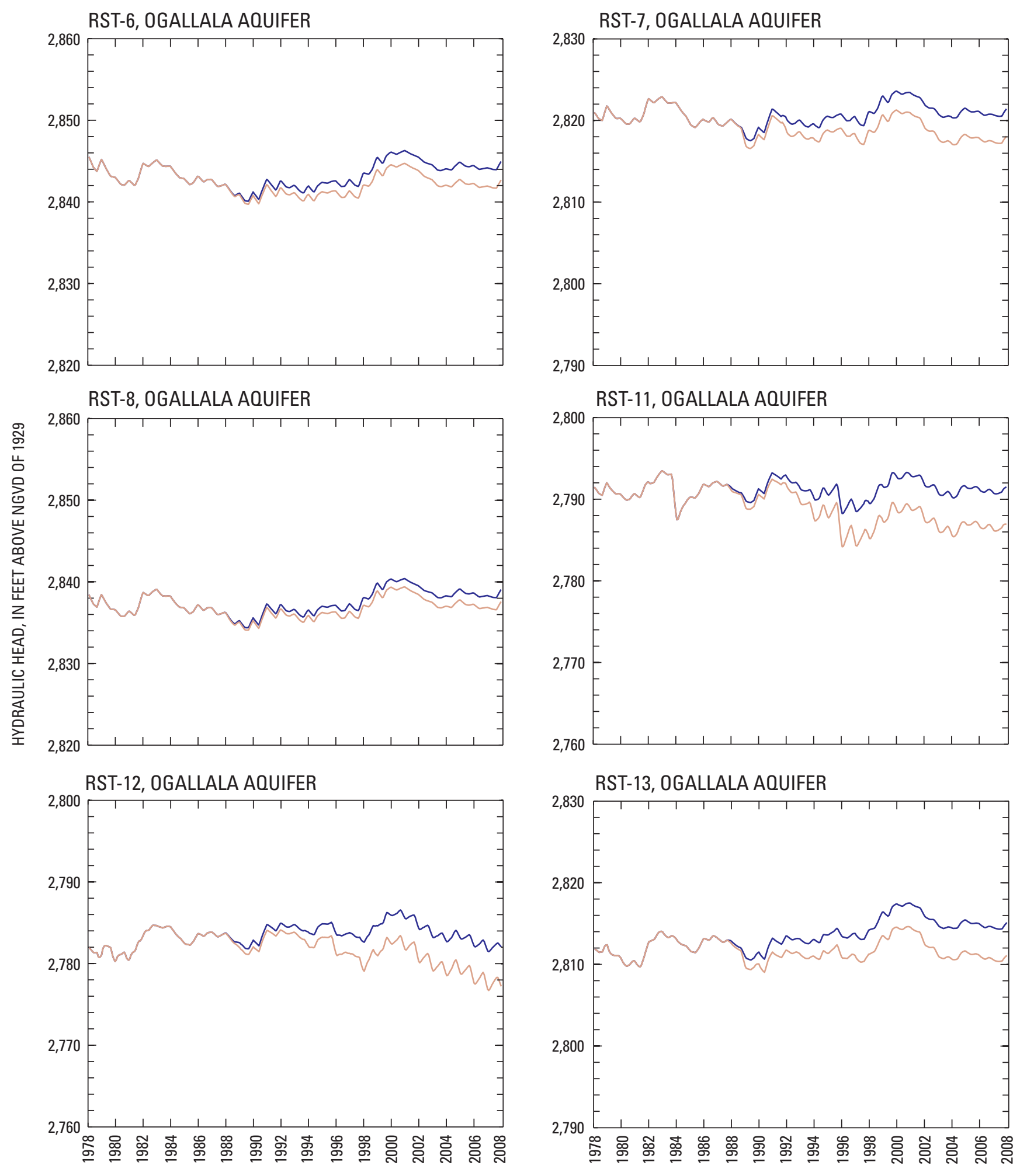

CALENDAR YEAR

\section{EXPLANATION}

Calibrated model

Increased groundwater withdrawals

Figure 25. Hydrographs showing the differences in water levels in wells between results of the calibrated model and the scenario of pumping increased by 50 percent for the 30-year simulation period for selected sites for the Ogallala aquifer. 


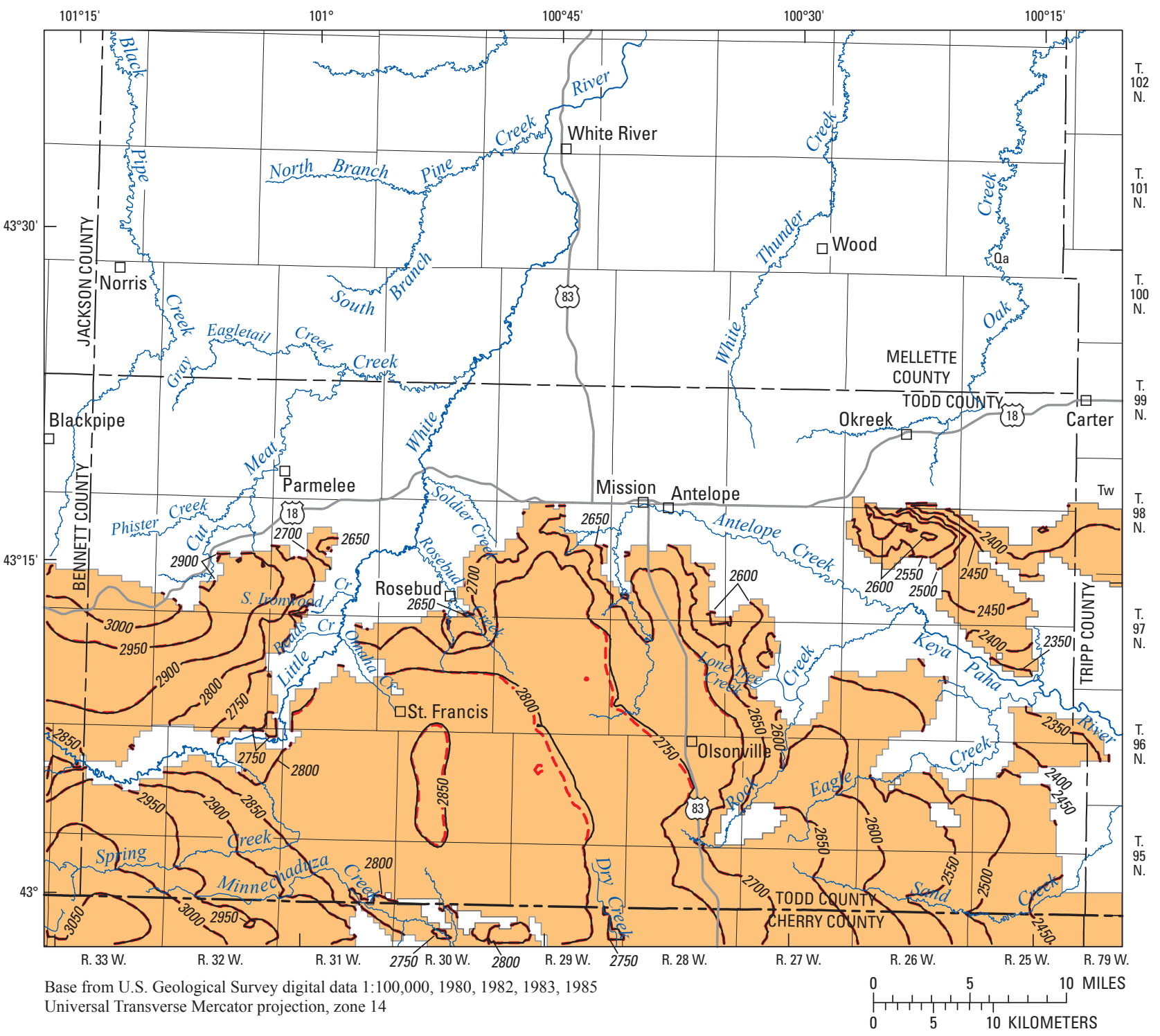

\section{EXPLANATION}

Ogallala aquifer active cells

-2800 - Simulated potentiometric contour for the calibrated model at the end of the 30-year simulation-Shows average altitude at which water level would have stood in tightly cased wells. Contour interval is 50 feet. Datum is NGVD of 1929

$--2850--$ Simulated potentiometric contour for the increased pumping scenario at the end of the 30-year simulation-Shows average altitude at which water level would have stood in tightly cased wells. Contour interval is 50 feet. Datum is NGVD of 1929

Figure 26. Simulated potentiometric surfaces for the calibrated model and the scenario of pumping increased by 50 percent at the end of a 30 -year simulation period for the 0 gallala aquifer. 


\section{Summary}

The Ogallala and Arikaree aquifers are important water resources in the Rosebud Indian Reservation area and are used extensively for irrigation, municipal, and domestic water supplies. Continued or increased withdrawals from the Ogallala and Arikaree aquifers in the Rosebud Indian Reservation area have the potential to affect water levels in these aquifers. A water-resource tool was needed to evaluate management and environmental issues associated with the Ogallala and Arikaree aquifers, such as assessing the effects of drought and potential increases in groundwater withdrawals. To address this need, the U.S. Geological Survey has worked in cooperation with the Rosebud Sioux Tribe to revise and recalibrate a previously published three-dimensional, numerical groundwater-flow model for this area by using data from October 1978 through September 2008.

The model had two layers to represent the Ogallala and Arikaree aquifers. The model grid had 168 rows and 202 columns, most of which were 1,640 feet (500 meters) wide, with narrower rows and columns near large watersupply wells. Data for a 30-year period (water years 1979 through 2008) were used in steady-state and transient numerical simulations of groundwater flow. Revisions to the model include (1) extension of the transient calibration period by 10 years, (2) the use of inverse modeling for steady-state calibration, (3) model calibration to base flow for an additional four surface-water drainage basins, (4) improved estimation of transient aquifer recharge, (5) improved delineation of vegetation types, and (6) reduced cell size near large capacity water-supply wells. In addition, potential future scenarios were simulated to assess the potential effects of drought and increased groundwater withdrawals.

Recharge to the Ogallala and Arikaree aquifers occurs from precipitation on the outcrop areas, and regional flow enters the study area from the west. Groundwater originating from precipitation recharge moves from areas of higher altitude toward streams that gain flow from the Ogallala and Arikaree aquifers. Discharge from the Ogallala and Arikaree aquifers occurs through evapotranspiration, discharge to streams and springs, and well withdrawals. Well withdrawals in the study area are for irrigation, municipal, domestic, and stock use, the largest of which is for irrigation. Evapotranspiration generally occurs in topographically low areas and along streams. Maximum evapotranspiration occurs only when the water level is at the land surface.

Multiple streamflow measurements were made in the study area to obtain information describing stream base flow. Average base flow was estimated for six surface-water drainage basins in the study area, including the Little White and Keya Paha Rivers, which were estimated to have average base flows of 49 and 23 cubic feet per second, respectively. The four smaller drainage basins (Cut Meat Creek, Black Pipe Creek, Minnechaduza Creek, and Sand Creek) were estimated to have a total average base flow of 9.8 cubic feet per second.
These estimates are inclusive of spring flow along stream banks.

Average inflow and outflow rates for water years 19792008 were used in the steady-state simulation, whereas the time-varying rates were used in the transient simulation. The steady-state model was calibrated to average water levels in 383 wells and estimated average base-flow rates for 6 surfacewater drainage basins. Inverse modeling techniques were used for steady-state model calibration. These methods were designed to estimate parameter values that are, statistically, the most likely set of values to result in the smallest overall differences between simulated and observed hydraulic heads and base-flow discharges. Parameters estimated by this method were hydraulic conductivity, recharge, maximum evapotranspiration, riverbed conductance, and spring conductance.

The average recharge rates used for the steady-state simulation were 2.91 and 1.45 inches per year applied to outcrops of the Ogallala and Arikaree aquifers, respectively, for a total rate of 255.4 cubic feet per second. Total inflow from model boundaries for the steady-state simulation was 12.5 cubic feet per second. Discharge rates in cubic feet per second for the steady-state simulation were 171.3 for evapotranspiration, 74.4 for net outflow to streams and springs, 11.6 for well withdrawals, and 9.9 as outflow from model boundaries. Estimated horizontal hydraulic conductivity used for the numerical model ranged from 0.2 to 84.4 feet per day for the Ogallala aquifer and 0.1 to 4.3 feet per day for the Arikaree aquifer. A uniform vertical hydraulic conductivity value of $4.2 \times 10^{-4}$ feet per day was estimated for the Ogallala aquifer. Vertical hydraulic conductivity was estimated for five zones in the Arikaree aquifer and ranged from $8.8 \times 10^{-5}$ to 3.7 feet per day.

For the steady-state simulation, the root mean square error for simulated hydraulic heads for all wells was 27.3 feet. Simulated hydraulic heads were within \pm 50 feet of observed values for 93 percent of the 383 wells. For the transient simulation, the difference between the simulated and observed means for hydrographs was within \pm 40 feet for 98 percent of 44 observation wells. The potentiometric surfaces of the two aquifers calculated by the steady-state simulation established initial conditions for the transient simulation. A sensitivity analysis was used to examine the response of the calibrated steady-state model to changes in model parameter values. The model was most sensitive to recharge and maximum evapotranspiration and least sensitive to riverbed and spring conductances.

To simulate a potential future drought scenario, a synthetic recharge record was created, the mean of which was equal to 64 percent of the average estimated recharge rate for the 30 -year calibration period. This synthetic recharge record was used to simulate the last 20 years of the calibration period under drought conditions. Compared with results of the calibrated model, decreases in hydraulic-head values for the drought scenario at the end of the simulation period were as much as 39 feet for the Ogallala aquifer. To simulate the effects of potential increases in pumping, well withdrawal 
rates were increased by 50 percent from those estimated for the 30-year calibration period for the last 20 years of the calibration period. Compared with results of the calibrated model, decreases in hydraulic-head values for the scenario of increased pumping at the end of the simulation period were as much as 13 feet for the Ogallala aquifer.

This numerical model is suitable as a tool to help understand the flow system, to help confirm that previous estimates of aquifer properties were reasonable, and to estimate aquifer properties in areas without data. The model also is useful to help assess the effects of drought and increases in pumping by simulations of these scenarios, the results of which are not precise but may be considered when making water management decisions. Limitations of the model should be taken into account when applying the model to water management.

\section{References Cited}

Bradley, Edward, 1956, Geology and groundwater resources of the Upper Niobrara River Basin, Nebraska and Wyoming: U.S. Geological Survey Water-Supply Paper 1368, $70 \mathrm{p}$.

Carter, J.M., 1998, Water resources of Mellette and Todd Counties, South Dakota: U.S. Geological Survey WaterResources Investigations Report 98-4146, 68 p.

Doherty, J., 2004, PEST-Model-independent parameter estimation user manual (5th ed.): Watermark Numerical Computing, variously paged, accessed December 2, 2009, at http://www.pesthomepage.org/files/pestman.pdf.

Ellis, M.J., Ficken, J.H., and Adolphson, D.G., 1971, Hydrology of the Rosebud Indian Reservation, South Dakota: U.S. Geological Survey Hydrologic Investigations Atlas HA-335, 2 sheets, scale 1:100,000.

Farnsworth, R.K., Thompson, E.S., and Peck, E.L., 1982, Evaporation atlas for the contiguous 48 United States: National Oceanic and Atmospheric Administration Technical Report NWS 33, 26 p.

Fenneman, N.M., 1946, Physical divisions of the United States: U.S. Geological Survey map prepared in cooperation with the Physiographic Commission, U.S. Geological Survey, scale 1:700,000 (reprinted 1964).

Flint, R.F., 1955, Pleistocene geology of eastern South Dakota: U.S. Geological Survey Professional Paper 262, 173 p.

Gutentag, E.D., Heimes, F.J., Krothe, N.C., Luckey, R.R., and Weeks, J.B., 1984, Geohydrology of the High Plains aquifer in parts of Colorado, Kansas, Nebraska, New Mexico, Oklahoma, South Dakota, Texas, and Wyoming: U.S. Geological Survey Professional Paper 1400-B, 63 p.
Harbaugh, A.W., Banta, E.R., Hill, M.C., and McDonald, M.G., 2000, MODFLOW-2000, the U.S. Geological Survey modular ground-water model-User guide to modularization concepts and the ground-water flow process: U.S. Geological Survey Open-File Report 00-92, 121 p.

Jakeman, A.J., and Hornberger, G.M., 1993, How much complexity is warranted in a rainfall-runoff model?: Water Resources Research, v. 29, no. 8, p. 2,637-2,649.

Kolm, K.E., and Case, H.L., III, 1983, A two-dimensional, finite-difference model of the High Plains aquifer in southern South Dakota: U.S. Geological Survey Water-Resources Investigations Report 83-4175, 34 p.

Langbein, W.B., 1949, Annual runoff in the United States: U.S. Geological Survey Circular 52, 14 p.

Levenberg, K., 1944, A method for the solution of certain non-linear problems in least squares: Quarterly of Applied Mathematics, v. 2, p. 164-168.

Long, A.J., Putnam, L.D., and Carter, J.M., 2003, Groundwater flow model of the Ogallala and Arikaree aquifers in the Rosebud Indian Reservation area, South Dakota: U.S. Geological Survey Water-Resources Investigations Report 03-4043, 69 p.

Long, A.J., 2009, Hydrograph separation for karst watersheds using a two-domain rainfall-discharge model: Journal of Hydrology, v. 364, no. 3-4, p. 249-256.

Marquardt, D.W., 1963. An algorithm for least-squares estimation of nonlinear parameters: Journal of the Society for Industrial and Applied Mathematics, v. 11, no. 2, p. 431-441.

Maupin, M.A., and Barber, N.L., 2005, Estimated withdrawals from principal aquifers in the United States, 2000: U.S. Geological Survey Circular 1279, 52 p., accessed May 6, 2010, at http://pubs.er.usgs.gov/usgspubs/cir/cir1279.

McDonald, M.G., and Harbaugh, A.W., 1988, A modular three-dimensional finite-difference ground-water flow model: U.S. Geological Survey Techniques of WaterResources Investigations, book 6, chap. A1 [variously paged].

McGuire, V.L., 2009, Water-level changes in the High Plains aquifer, predevelopment to 2007, 2005-06, and 2006-07: U.S. Geological Survey Scientific Investigations Report 2009-5019, 9 p., accessed February 22, 2010, at http://pubs.usgs.gov/sir/2009/5019/.

Multi-Resolution Land Characteristics Consortium, 2009, National Land Cover Database 2001, accessed July 10, 2009, at http://www.mrlc.gov/nlcd.php. 
National Climatic Data Center, 2010, NOAA Satellite and Information Service, accessed February 22, 2010, at http://www.ncdc.noaa.gov/oa/climate/stationlocator.html.

National Elevation Dataset, 2006, The Seamless Data Distribution System (SDDS), access May 19, 2010, at http://ned.usgs.gov/.

Rahn, P.H., and Paul, H.A., 1975, Hydrogeology of a portion of the Sand Hills and Ogallala aquifer, South Dakota and Nebraska: Ground Water, v. 13, no. 5, p. 428-437.

Rantz, S.E. and others, 1982, Measurement and computation of streamflow, Volume 1, Measurement of stage and | discharge: U.S. Geological Survey Water-Supply Paper 2175, 284 p., accessed 24 February 2010 at http://pubs.er.usgs.gov/usgspubs/wsp/wsp2175_vol1.
Springer, R.F., 1974, Soil survey of Todd County, South Dakota: U.S. Department of Agriculture, 89 p.

U.S. Geological Survey, 1955, Martin, South Dakota: U.S. Geological Survey Topographic Map, scale 1:250,000.

U.S. Geological Survey, 2009, Water use in the United States: U.S. Geological Survey database, accessed November 30, 2009, at http://water.usgs.gov/watuse/. 
Appendix 1 
Appendix 1. Wells used for estimating potentiometric surfaces of the Ogallala and Arikaree aquifers.

[Hydraulic heads are estimated averages for water years 1979-98. NGVD of 1929, National Geodetic Vertical Datum of 1929. --, not applicable or unknown]

\begin{tabular}{|c|c|c|c|c|c|c|}
\hline $\begin{array}{c}\text { Site identification } \\
\text { number }\end{array}$ & Legal location & Aquifer & $\begin{array}{l}\text { Land surface al- } \\
\text { titude (feet above } \\
\text { NGVD of 1929) }\end{array}$ & $\begin{array}{l}\text { Well depth } \\
\text { (feet) }\end{array}$ & $\begin{array}{l}\text { Average hydraulic } \\
\text { head (feet above } \\
\text { NGVD of 1929) }\end{array}$ & $\begin{array}{c}\text { Observation } \\
\text { well name }\end{array}$ \\
\hline 430239100174301 & $35 \mathrm{~N} 25 \mathrm{~W}$ 5BBAA & Ogallala & 2,518 & 72 & 2,510 & -- \\
\hline 430200100164801 & 35N25W 5DDD & Ogallala & 2,501 & 100 & 2,496 & -- \\
\hline 430242100184801 & $35 \mathrm{~N} 25 \mathrm{~W} 6 \mathrm{BBA}$ & Arikaree & 2,525 & 100 & 2,513 & -- \\
\hline 430151100173901 & $35 \mathrm{~N} 25 \mathrm{~W} 8 \mathrm{BB}$ & Ogallala & 2,513 & 90 & 2,496 & -- \\
\hline 430023100115602 & 35N25W13DADD2 & Ogallala & 2,443 & 160 & 2,434 & -- \\
\hline 430002100174801 & $35 \mathrm{~N} 25 \mathrm{~W} 20 \mathrm{BBBC}$ & Ogallala & 2,493 & 47 & 2,489 & -- \\
\hline 430003100174802 & $35 \mathrm{~N} 25 \mathrm{~W} 20 \mathrm{BBBC} 3$ & Arikaree & 2,493 & 120 & 2,488 & -- \\
\hline 430204100212001 & $35 \mathrm{~N} 26 \mathrm{~W} 3 \mathrm{DDAB}$ & Arikaree & 2,617 & 120 & 2,593 & -- \\
\hline 430237100241201 & $35 \mathrm{~N} 26 \mathrm{~W} 5 \mathrm{BA}$ & Ogallala & 2,635 & 70 & 2,603 & -- \\
\hline 430216100252101 & $35 \mathrm{~N} 26 \mathrm{~W} 6 \mathrm{DBBA}$ & Arikaree & 2,620 & 132 & 2,558 & -- \\
\hline 430127100230601 & 35N26W 9BDAD & Arikaree & 2,585 & 100 & 2,558 & -- \\
\hline 430126100222001 & $35 \mathrm{~N} 26 \mathrm{~W} 10 \mathrm{CBBA} 2$ & Ogallala & 2,618 & 82 & 2,573 & -- \\
\hline 430126100221901 & $35 \mathrm{~N} 26 \mathrm{~W} 10 \mathrm{CBBA} 3$ & Arikaree & 2,617 & 492 & 2,569 & -- \\
\hline 430033100203001 & $35 \mathrm{~N} 26 \mathrm{~W} 14 \mathrm{DB}$ & Ogallala & 2,530 & 28 & 2,520 & -- \\
\hline 430040100233901 & $35 \mathrm{~N} 26 \mathrm{~W} 17 \mathrm{DAB}$ & Ogallala & 2,583 & 60 & 2,576 & -- \\
\hline 430033100234902 & $35 \mathrm{~N} 26 \mathrm{~W} 17 \mathrm{DAB} 2$ & Arikaree & 2,583 & 103 & 2,565 & -- \\
\hline 430006100254301 & $35 \mathrm{~N} 26 \mathrm{~W} 19 \mathrm{BBAC}$ & Ogallala & 2,660 & 100 & 2,623 & -- \\
\hline 430236100274201 & $35 \mathrm{~N} 27 \mathrm{~W} 2 \mathrm{ABCC}$ & Ogallala & 2,700 & 90 & 2,628 & -- \\
\hline 430215100273301 & $35 \mathrm{~N} 27 \mathrm{~W} 2 \mathrm{DBCC}$ & Ogallala & 2,695 & -- & 2,658 & -- \\
\hline 430245100292801 & $35 \mathrm{~N} 27 \mathrm{~W} 3 \mathrm{BBBB}$ & Ogallala & 2,671 & 47 & 2,660 & -- \\
\hline 430245100292701 & $35 \mathrm{~N} 27 \mathrm{~W} 3 \mathrm{BBBB} 4$ & Arikaree & 2,671 & 202 & 2,660 & -- \\
\hline 430230100320301 & $35 \mathrm{~N} 27 \mathrm{~W} 6 \mathrm{AAC}$ & Ogallala & 2,710 & -- & 2,679 & -- \\
\hline 430121100323001 & $35 \mathrm{~N} 27 \mathrm{~W} 7 \mathrm{CACB}$ & Ogallala & 2,724 & 120 & 2,698 & -- \\
\hline 430115100322101 & $35 \mathrm{~N} 27 \mathrm{~W} 7 \mathrm{DACC}$ & Ogallala & 2,731 & 120 & 2,705 & -- \\
\hline 430119100291801 & $35 \mathrm{~N} 27 \mathrm{~W} 10 \mathrm{CBBB}$ & Ogallala & 2,717 & 100 & 2,686 & -- \\
\hline 430103100280601 & $35 \mathrm{~N} 27 \mathrm{~W} 11 \mathrm{CCDC}$ & Ogallala & 2,682 & 120 & 2,651 & -- \\
\hline 430106100271403 & $35 \mathrm{~N} 27 \mathrm{~W} 11 \mathrm{DD}$ & Ogallala & 2,637 & 80 & 2,623 & -- \\
\hline 430106100271402 & 35N27W11DD2 & Arikaree & 2,637 & 120 & 2,611 & -- \\
\hline 430139100264401 & $35 \mathrm{~N} 27 \mathrm{~W} 12 \mathrm{~B}$ & Ogallala & 2,636 & 85 & 2,619 & -- \\
\hline 430057100275401 & $35 \mathrm{~N} 27 \mathrm{~W} 14 \mathrm{BAAB}$ & Ogallala & 2,690 & 84 & 2,671 & RST-21 \\
\hline 430022100270901 & 35N27W14DAA & Ogallala & 2,676 & 50 & 2,666 & -- \\
\hline 430039100301001 & $35 \mathrm{~N} 27 \mathrm{~W} 16 \mathrm{BD}$ & Ogallala & 2,695 & 55 & 2,678 & -- \\
\hline 430039100320801 & $35 \mathrm{~N} 27 \mathrm{~W} 18 \mathrm{~A}$ & Ogallala & 2,725 & 55 & 2,709 & -- \\
\hline 430000100285401 & $35 \mathrm{~N} 27 \mathrm{~W} 22 \mathrm{ABBC}$ & Arikaree & 2,679 & 75 & 2,668 & -- \\
\hline 430154100332601 & 35N28W 1DC & Arikaree & 2,683 & 100 & 2,673 & -- \\
\hline 430217100370801 & $35 \mathrm{~N} 28 \mathrm{~W} 4 \mathrm{ACCB}$ & Arikaree & 2,753 & 140 & 2,719 & -- \\
\hline 430122100344501 & $35 \mathrm{~N} 28 \mathrm{~W} 11 \mathrm{DBBB}$ & Ogallala & 2,728 & 94 & 2,711 & RST-20 \\
\hline 430613100352901 & $35 \mathrm{~N} 28 \mathrm{~W} 14 \mathrm{AAAA}$ & Arikaree & 2,735 & 120 & 2,722 & -- \\
\hline 430055100362702 & $35 \mathrm{~N} 28 \mathrm{~W} 15 \mathrm{BBBD} 2$ & Ogallala & 2,754 & 76 & 2,744 & -- \\
\hline 430154100411801 & 35N29W 2DDDD & Ogallala & 2,800 & 44 & 2,792 & RST-10 \\
\hline 430156100411901 & 35N29W 2DDDD2 & Ogallala & 2,800 & 37 & 2,791 & -- \\
\hline 430238100434801 & $35 \mathrm{~N} 29 \mathrm{~W} 4 \mathrm{AA}$ & Ogallala & 2,830 & 50 & 2,810 & -- \\
\hline 430226100445201 & $35 \mathrm{~N} 29 \mathrm{~W} 4 \mathrm{BCCB}$ & Arikaree & 2,845 & 113 & 2,832 & -- \\
\hline
\end{tabular}


Appendix 1. Wells used for estimating potentiometric surfaces of the Ogallala and Arikaree aquifers.-Continued

[Hydraulic heads are estimated averages for water years 1979-98. NGVD of 1929, National Geodetic Vertical Datum of 1929. --, not applicable or unknown]

\begin{tabular}{|c|c|c|c|c|c|c|}
\hline $\begin{array}{c}\text { Site identification } \\
\text { number }\end{array}$ & Legal location & Aquifer & $\begin{array}{l}\text { Land surface al- } \\
\text { titude (feet above } \\
\text { NGVD of 1929) }\end{array}$ & $\begin{array}{l}\text { Well depth } \\
\text { (feet) }\end{array}$ & $\begin{array}{l}\text { Average hydraulic } \\
\text { head (feet above } \\
\text { NGVD of 1929) }\end{array}$ & $\begin{array}{l}\text { Observation } \\
\text { well name }\end{array}$ \\
\hline 430226100445203 & 35N29W 4BCCB3 & Ogallala & 2,845 & 27 & 2,829 & -- \\
\hline 430225100445401 & 35N29W 5DDDA & Arikaree & 2,880 & 135 & 2,783 & -- \\
\hline 430148100471001 & $35 \mathrm{~N} 29 \mathrm{~W} 7 \mathrm{BBBB}$ & Ogallala & 2,903 & 83 & 2,837 & TD-59A \\
\hline 430151100415402 & $35 \mathrm{~N} 29 \mathrm{~W} 11 \mathrm{ABBB} 2$ & Ogallala & 2,800 & 110 & 2,780 & -- \\
\hline 430048100450201 & 35N29W17AACD & Arikaree & 2,913 & 190 & 2,831 & -- \\
\hline 430014100445401 & 35N29W17DDDA & Arikaree & 2,878 & 140 & 2,851 & -- \\
\hline 430100100460501 & 35N29W18AAAA & Ogallala & 2,870 & 84 & 2,831 & RST-9 \\
\hline 425957100445601 & 35N29W20AADD & Ogallala & 2,890 & 128 & 2,804 & TD-59B \\
\hline 430212100524001 & 35N30W 5CA & Ogallala & 2,828 & 105 & 2,809 & -- \\
\hline 430153100521303 & $35 \mathrm{~N} 30 \mathrm{~W}$ 5DDCC3 & Ogallala & 2,842 & 108 & 2,822 & -- \\
\hline 430217100535201 & 35N30W 6CABA & Ogallala & 2,873 & 105 & 2,834 & -- \\
\hline 430159100531001 & 35N30W 6DDDD & Ogallala & 2,853 & 84 & 2,832 & RST-5 \\
\hline 430113100491601 & $35 \mathrm{~N} 30 \mathrm{~W} 11 \mathrm{C}$ & Arikaree & 2,910 & 260 & 2,824 & -- \\
\hline 430139100474801 & $35 \mathrm{~N} 30 \mathrm{~W} 12 \mathrm{ACBB}$ & Ogallala & 2,935 & 160 & 2,875 & -- \\
\hline 430037100471601 & 35N30W13ADD & Ogallala & 2,895 & 140 & 2,785 & -- \\
\hline 430045100495701 & $35 \mathrm{~N} 30 \mathrm{~W} 15 \mathrm{ACA}$ & Ogallala & 2,880 & 125 & 2,850 & -- \\
\hline 430231100591501 & 35N31W 5AACC & Ogallala & 2,865 & 70 & 2,850 & -- \\
\hline 430142100580301 & $35 \mathrm{~N} 31 \mathrm{~W} 9 \mathrm{AACD}$ & Arikaree & 2,840 & 120 & 2,812 & -- \\
\hline 430120100574901 & $35 \mathrm{~N} 31 \mathrm{~W} 10 \mathrm{CBBC}$ & Ogallala & 2,823 & 57 & 2,818 & -- \\
\hline 430021100543301 & 35N31W13D & Arikaree & 2,840 & 125 & 2,783 & -- \\
\hline 430042100565801 & $35 \mathrm{~N} 31 \mathrm{~W} 15 \mathrm{ACA}$ & Ogallala & 2,822 & 75 & 2,815 & -- \\
\hline 430017100595101 & $35 \mathrm{~N} 31 \mathrm{~W} 17 \mathrm{CCDA}$ & Ogallala & 2,896 & 62 & 2,893 & RST-4 \\
\hline 430113101062401 & $35 \mathrm{~N} 32 \mathrm{~W} 8 \mathrm{D}$ & Ogallala & 2,980 & 80 & 2,975 & -- \\
\hline 430152101054803 & $35 \mathrm{~N} 32 \mathrm{~W} 9 \mathrm{BABB} 3$ & Ogallala & 2,935 & 67 & 2,928 & -- \\
\hline 430153101054902 & $35 \mathrm{~N} 32 \mathrm{~W} 9 \mathrm{BABB} 5$ & Arikaree & 2,938 & 452 & 2,931 & -- \\
\hline 430047101025001 & $35 \mathrm{~N} 32 \mathrm{~W} 14 \mathrm{~A}$ & Ogallala & 2,982 & 105 & 2,913 & -- \\
\hline 430028101111701 & $35 \mathrm{~N} 33 \mathrm{~W} 15 \mathrm{DB}$ & Ogallala & 3,060 & 90 & 3,035 & -- \\
\hline 425956101134503 & $35 \mathrm{~N} 33 \mathrm{~W} 20 \mathrm{ABCC} 3$ & Ogallala & 3,050 & 165 & 3,032 & -- \\
\hline 430727100170304 & 36N25W 5DBD & Arikaree & 2,440 & 45 & 2,428 & -- \\
\hline 430704100145901 & $36 \mathrm{~N} 25 \mathrm{~W} 10 \mathrm{BABB}$ & Ogallala & 2,442 & 30 & 2,421 & -- \\
\hline 430348100172001 & $36 \mathrm{~N} 25 \mathrm{~W} 29 \mathrm{CDAC}$ & Ogallala & 2,573 & 120 & 2,526 & -- \\
\hline 430326100185001 & $36 \mathrm{~N} 25 \mathrm{~W} 31 \mathrm{ABC}$ & Arikaree & 2,597 & 100 & 2,550 & -- \\
\hline 430315100184301 & $36 \mathrm{~N} 25 \mathrm{~W} 31 \mathrm{BDCB}$ & Ogallala & 2,552 & 70 & 2,530 & -- \\
\hline 430331100153301 & $36 \mathrm{~N} 25 \mathrm{~W} 33 \mathrm{AA}$ & Ogallala & 2,585 & 70 & 2,514 & -- \\
\hline 430700100225701 & $36 \mathrm{~N} 26 \mathrm{~W} 9 \mathrm{AB}$ & Arikaree & 2,505 & 120 & 2,498 & -- \\
\hline 430607100212101 & $36 \mathrm{~N} 26 \mathrm{~W} 15 \mathrm{AAAB}$ & Arikaree & 2,505 & 100 & 2,448 & -- \\
\hline 430528100242001 & 36N26W17CDD & Arikaree & 2,554 & 50 & 2,534 & -- \\
\hline 430454100255101 & 36N26W19BBC & Ogallala & 2,650 & 120 & 2,608 & -- \\
\hline 430455100241301 & 36N26W20CAD & Arikaree & 2,537 & 140 & 2,525 & -- \\
\hline 430515100225001 & 36N26W21AAB & Ogallala & 2,585 & 120 & 2,543 & -- \\
\hline 430424100214301 & $36 \mathrm{~N} 26 \mathrm{~W} 27 \mathrm{ABBB}$ & Arikaree & 2,588 & 130 & 2,546 & -- \\
\hline 430310100245501 & 36N26W31ADDD & Ogallala & 2,620 & 125 & 2,594 & TD-80E \\
\hline 430335100241401 & 36N26W32BBAA & Ogallala & 2,619 & 78 & 2,589 & RST-22 \\
\hline
\end{tabular}


Appendix 1. Wells used for estimating potentiometric surfaces of the Ogallala and Arikaree aquifers.-Continued [Hydraulic heads are estimated averages for water years 1979-98. NGVD of 1929, National Geodetic Vertical Datum of 1929. --, not applicable or unknown]

\begin{tabular}{|c|c|c|c|c|c|c|}
\hline $\begin{array}{c}\text { Site identification } \\
\text { number }\end{array}$ & Legal location & Aquifer & $\begin{array}{l}\text { Land surface al- } \\
\text { titude (feet above } \\
\text { NGVD of 1929) }\end{array}$ & $\begin{array}{l}\text { Well depth } \\
\text { (feet) }\end{array}$ & $\begin{array}{l}\text { Average hydraulic } \\
\text { head (feet above } \\
\text { NGVD of 1929) }\end{array}$ & $\begin{array}{c}\text { Observation } \\
\text { well name }\end{array}$ \\
\hline 430246100222302 & $36 \mathrm{~N} 26 \mathrm{~W} 34 \mathrm{CCC} 2$ & Ogallala & 2,634 & 110 & 2,607 & -- \\
\hline 430727100262801 & $36 \mathrm{~N} 27 \mathrm{~W} 1$ & Arikaree & 2,650 & 128 & 2,597 & -- \\
\hline 430728100135801 & $36 \mathrm{~N} 27 \mathrm{~W} 1 \mathrm{BDDD}$ & Ogallala & 2,627 & 58 & 2,600 & RST-23 \\
\hline 430721100290001 & $36 \mathrm{~N} 27 \mathrm{~W} 3 \mathrm{CA}$ & Ogallala & 2,663 & 150 & 2,602 & -- \\
\hline 430705100304701 & 36N27W 5DDD & Ogallala & 2,600 & 120 & 2,579 & -- \\
\hline 430512100291801 & $36 \mathrm{~N} 27 \mathrm{~W} 15 \mathrm{CC}$ & Ogallala & 2,698 & 150 & 2,622 & -- \\
\hline 430458100300901 & 36N27W21BDDB & Ogallala & 2,664 & 90 & 2,613 & -- \\
\hline 430451100290001 & $36 \mathrm{~N} 27 \mathrm{~W} 22 \mathrm{CDBA}$ & Arikaree & 2,638 & 75 & 2,628 & -- \\
\hline 430410100261701 & $36 \mathrm{~N} 27 \mathrm{~W} 25 \mathrm{ADBB}$ & Arikaree & 2,658 & 205 & 2,614 & -- \\
\hline 430412100323001 & $36 \mathrm{~N} 27 \mathrm{~W} 30 \mathrm{BDA}$ & Arikaree & 2,693 & 140 & 2,673 & -- \\
\hline 430245100272401 & 36N27W35DCD & Arikaree & 2,673 & 144 & 2,647 & -- \\
\hline 430737100350602 & $36 \mathrm{~N} 28 \mathrm{~W} 2 \mathrm{BDAC} 2$ & Ogallala & 2,773 & 167 & 2,677 & -- \\
\hline 430719101380501 & $36 \mathrm{~N} 28 \mathrm{~W} 5 \mathrm{DACC}$ & Ogallala & 2,818 & 140 & 2,783 & -- \\
\hline 430604100390801 & 36N28W 7DDB & Ogallala & 2,829 & 214 & 2,793 & -- \\
\hline 430649100364801 & 36N28W 9ADDA & Ogallala & 2,805 & 70 & 2,764 & -- \\
\hline 430701100363001 & $36 \mathrm{~N} 28 \mathrm{~W} 10 \mathrm{BBBB}$ & Ogallala & 2,823 & 183 & 2,750 & TD-76J \\
\hline 430700100344501 & $36 \mathrm{~N} 28 \mathrm{~W} 11 \mathrm{ABB}$ & Ogallala & 2,807 & 140 & 2,707 & -- \\
\hline 430702100330501 & $36 \mathrm{~N} 28 \mathrm{~W} 12 \mathrm{AABA}$ & Ogallala & 2,806 & 215 & 2,660 & RST-18 \\
\hline 430618100330301 & $36 \mathrm{~N} 28 \mathrm{~W} 12 \mathrm{DD}$ & Ogallala & 2,675 & 20 & 2,669 & -- \\
\hline 430614100362503 & $36 \mathrm{~N} 28 \mathrm{~W} 15 \mathrm{BABB} 3$ & Ogallala & 2,778 & 75 & 2,753 & -- \\
\hline 430601100364501 & $36 \mathrm{~N} 28 \mathrm{~W} 16 \mathrm{ABCA}$ & Ogallala & 2,805 & 40 & 2,779 & -- \\
\hline 430454100341801 & 36N28W23DAAC & Arikaree & 2,730 & 120 & 2,712 & -- \\
\hline 430515100331201 & 36N28W24AAA & Ogallala & 2,685 & 140 & 2,665 & -- \\
\hline 430448100332401 & 36N28W24ACA & Arikaree & 2,655 & 40 & 2,645 & -- \\
\hline 430406100380701 & 36N28W29ACDC & Ogallala & 2,771 & 40 & 2,756 & -- \\
\hline 430403100395001 & 36N28W30BCDD & Ogallala & 2,820 & 100 & 2,801 & -- \\
\hline 430348100390401 & 36N28W30DDAB & Ogallala & 2,792 & 100 & 2,773 & -- \\
\hline 430314100392301 & 36N28W31ACDC & Ogallala & 2,839 & 95 & 2,819 & -- \\
\hline 430243100371701 & 36N28W33BDDD & Ogallala & 2,753 & 75 & 2,723 & RST-19 \\
\hline 430712100421301 & $36 \mathrm{~N} 29 \mathrm{~W} 2 \mathrm{CDCC}$ & Ogallala & 2,850 & 200 & 2,804 & RST-12 \\
\hline 430714100445001 & $36 \mathrm{~N} 29 \mathrm{~W} 4 \mathrm{CCBC}$ & Ogallala & 2,853 & 150 & 2,816 & -- \\
\hline 430624100461601 & 36N29W 7DDB & Ogallala & 2,925 & 190 & 2,890 & -- \\
\hline 430659100434901 & 36N29W 9AA & Ogallala & 2,845 & 200 & 2,778 & -- \\
\hline 430629100434401 & 36N29W 9DAD & Ogallala & 2,885 & 209 & 2,817 & -- \\
\hline 430530100422501 & 36N29W14CDAB & Ogallala & 2,893 & 200 & 2,811 & RST-11 \\
\hline 430522100411902 & 36N29W14DDDD2 & Ogallala & 2,884 & 225 & 2,815 & -- \\
\hline 430558100430301 & $36 \mathrm{~N} 29 \mathrm{~W} 15 \mathrm{ACBB}$ & Ogallala & 2,884 & 160 & 2,866 & -- \\
\hline 430609100434201 & 36N29W16AAAA & Ogallala & 2,863 & 222 & 2,822 & TD-76F \\
\hline 430604100445201 & 36N29W17AADD R & Ogallala & 2,905 & 243 & 2,823 & -- \\
\hline 430603100460501 & 36N29W18AADD & Ogallala & 2,940 & 123 & 2,850 & -- \\
\hline 430450100453701 & $36 \mathrm{~N} 29 \mathrm{~W} 20 \mathrm{CA}$ & Ogallala & 2,868 & 140 & 2,845 & -- \\
\hline 430508100431901 & $36 \mathrm{~N} 29 \mathrm{~W} 22 \mathrm{BBDD}$ & Ogallala & 2,911 & 230 & 2,831 & -- \\
\hline 430415100451401 & 36N29W29ACAA & Ogallala & 2,870 & 134 & 2,851 & RST-7 \\
\hline
\end{tabular}


Appendix 1. Wells used for estimating potentiometric surfaces of the Ogallala and Arikaree aquifers. - Continued

[Hydraulic heads are estimated averages for water years 1979-98. NGVD of 1929, National Geodetic Vertical Datum of 1929. --, not applicable or unknown]

\begin{tabular}{|c|c|c|c|c|c|c|}
\hline $\begin{array}{c}\text { Site identification } \\
\text { number }\end{array}$ & Legal location & Aquifer & $\begin{array}{l}\text { Land surface al- } \\
\text { titude (feet above } \\
\text { NGVD of 1929) }\end{array}$ & $\begin{array}{l}\text { Well depth } \\
\text { (feet) }\end{array}$ & $\begin{array}{l}\text { Average hydraulic } \\
\text { head (feet above } \\
\text { NGVD of 1929) }\end{array}$ & $\begin{array}{c}\text { Observation } \\
\text { well name }\end{array}$ \\
\hline 430305100455401 & $36 \mathrm{~N} 29 \mathrm{~W} 32 \mathrm{CB}$ & Ogallala & 2,835 & 60 & 2,823 & -- \\
\hline 430252100431301 & $36 \mathrm{~N} 29 \mathrm{~W} 34 \mathrm{CD}$ & Ogallala & 2,804 & 100 & 2,794 & -- \\
\hline 430302100412001 & $36 \mathrm{~N} 29 \mathrm{~W} 35 \mathrm{DAD}$ & Ogallala & 2,834 & 45 & 2,819 & -- \\
\hline 430723100512101 & $36 \mathrm{~N} 30 \mathrm{~W} 4 \mathrm{DBCB}$ & Ogallala & 2,978 & 235 & 2,872 & -- \\
\hline 430627100532601 & 36N30W 7D & Arikaree & 2,960 & 187 & 2,856 & -- \\
\hline 430652100484001 & $36 \mathrm{~N} 30 \mathrm{~W} 11 \mathrm{ADBB}$ & Ogallala & 2,949 & 300 & 2,851 & -- \\
\hline 430615100472701 & 36N30W12DDCD & Ogallala & 2,960 & 285 & 2,827 & -- \\
\hline 430610100481701 & $36 \mathrm{~N} 30 \mathrm{~W} 13 \mathrm{BBBB}$ & Ogallala & 2,916 & 225 & 2,843 & TD-76E \\
\hline 430518100533701 & 36N30W19ABB & Ogallala & 2,902 & 145 & 2,855 & -- \\
\hline 430501100504901 & $36 \mathrm{~N} 30 \mathrm{~W} 22 \mathrm{CBBB}$ & Ogallala & 2,888 & 137 & 2,858 & RST-6 \\
\hline 430507100483701 & $36 \mathrm{~N} 30 \mathrm{~W} 23 \mathrm{ADBB}$ & Ogallala & 2,934 & 217 & 2,848 & -- \\
\hline 430342100482901 & 36N30W26DDDB & Ogallala & 2,851 & 50 & 2,832 & -- \\
\hline 430250100532701 & 36N30W31DCDA & Ogallala & 2,868 & 50 & 2,849 & -- \\
\hline 430327100512301 & $36 \mathrm{~N} 30 \mathrm{~W} 33 \mathrm{BADD}$ & Ogallala & 2,945 & 180 & 2,854 & -- \\
\hline 430334100515201 & 36N30W33BBB & Ogallala & 2,896 & 110 & 2,843 & -- \\
\hline 430254100515001 & $36 \mathrm{~N} 30 \mathrm{~W} 33 \mathrm{CCBD}$ & Ogallala & 2,879 & 50 & 2,856 & -- \\
\hline 430301100492101 & $36 \mathrm{~N} 30 \mathrm{~W} 35 \mathrm{CBCC}$ & Arikaree & 2,917 & 179 & 2,843 & -- \\
\hline 430258100471401 & 36N30W36DDDA & Ogallala & 2,885 & 123 & 2,836 & RST-8 \\
\hline 430721100563001 & $36 \mathrm{~N} 31 \mathrm{~W} 2 \mathrm{CBCD}$ & Ogallala & 2,934 & 200 & 2,785 & -- \\
\hline 430630100565401 & $36 \mathrm{~N} 31 \mathrm{~W} 10 \mathrm{DACD} 3$ & Arikaree & 2,958 & 305 & 2,736 & -- \\
\hline 430613100544901 & 36N31W12DCCD & Arikaree & 2,899 & 194 & 2,843 & -- \\
\hline 430613101561701 & 36N31W14BAAA & Ogallala & 2,955 & 160 & 2,816 & TD-79B \\
\hline 430541100555501 & $36 \mathrm{~N} 31 \mathrm{~W} 14 \mathrm{DB}$ & Ogallala & 2,970 & 140 & 2,871 & -- \\
\hline 430555100570301 & $36 \mathrm{~N} 31 \mathrm{~W} 15 \mathrm{ACAC}$ & Ogallala & 3,005 & 310 & 2,916 & -- \\
\hline 430603101003401 & 36N31W18ABDD & Ogallala & 2,877 & 98 & 2,839 & -- \\
\hline 430309100570901 & $36 \mathrm{~N} 31 \mathrm{~W} 34 \mathrm{DBBC}$ & Ogallala & 2,920 & 91 & 2,865 & RST-3 \\
\hline 430650101021001 & $36 \mathrm{~N} 32 \mathrm{~W} 1 \mathrm{DCDC}$ & Arikaree & 2,623 & 60 & 2,614 & -- \\
\hline 430721101032801 & $36 \mathrm{~N} 32 \mathrm{~W} 2 \mathrm{C}$ & Arikaree & 2,660 & 180 & 2,667 & -- \\
\hline 430712101042801 & $36 \mathrm{~N} 32 \mathrm{~W} 3 \mathrm{CD}$ & Arikaree & 2,686 & 118 & 2,631 & -- \\
\hline 430619101020501 & $36 \mathrm{~N} 32 \mathrm{~W} 12 \mathrm{CD} 2$ & Arikaree & 2,895 & 335 & 2,734 & -- \\
\hline 430612101014401 & $36 \mathrm{~N} 32 \mathrm{~W} 12 \mathrm{DD}$ & Arikaree & 2,842 & 340 & 2,674 & -- \\
\hline 430537101062801 & 36N32W17DBD & Arikaree & 2,860 & 205 & 2,820 & -- \\
\hline 430458101042001 & $36 \mathrm{~N} 32 \mathrm{~W} 22 \mathrm{CADA}$ & Ogallala & 2,850 & 40 & 2,821 & -- \\
\hline 430426101020201 & $36 \mathrm{~N} 32 \mathrm{~W} 25 \mathrm{BAA}$ & Ogallala & 2,845 & 55 & 2,811 & -- \\
\hline 430340101012301 & 36N32W25DDDD & Ogallala & 2,841 & 125 & 2,834 & TD-80B \\
\hline 431500101133301 & $36 \mathrm{~N} 33 \mathrm{~W} 21 \mathrm{BBC}$ & Arikaree & 2,985 & 160 & 2,860 & -- \\
\hline 431236100172601 & $37 \mathrm{~N} 25 \mathrm{~W} 4 \mathrm{BCCA}$ & Ogallala & 2,467 & 100 & 2,386 & -- \\
\hline 431254100191001 & $37 \mathrm{~N} 25 \mathrm{~W} 6 \mathrm{ABA}$ & Arikaree & 2,410 & 120 & 2,373 & -- \\
\hline 431211100194502 & $37 \mathrm{~N} 25 \mathrm{~W} 6 \mathrm{CCC} 2$ & Arikaree & 2,369 & 80 & 2,347 & -- \\
\hline 430908100175801 & 37N25W29ACDD & Arikaree & 2,374 & 60 & 2,360 & -- \\
\hline 430757100183301 & $37 \mathrm{~N} 25 \mathrm{~W} 32 \mathrm{CCAB}$ & Arikaree & 2,423 & 124 & 2,396 & -- \\
\hline 431245100210801 & $37 \mathrm{~N} 26 \mathrm{~W} 2 \mathrm{ADAA}$ & Arikaree & 2,383 & 109 & 2,351 & -- \\
\hline 431215100225801 & 37N26W 3CDA & Arikaree & 2,444 & 95 & 2,401 & -- \\
\hline
\end{tabular}


Appendix 1. Wells used for estimating potentiometric surfaces of the Ogallala and Arikaree aquifers. - Continued [Hydraulic heads are estimated averages for water years 1979-98. NGVD of 1929, National Geodetic Vertical Datum of 1929. --, not applicable or unknown]

\begin{tabular}{|c|c|c|c|c|c|c|}
\hline $\begin{array}{c}\text { Site identification } \\
\text { number }\end{array}$ & Legal location & Aquifer & $\begin{array}{l}\text { Land surface al- } \\
\text { titude (feet above } \\
\text { NGVD of 1929) }\end{array}$ & $\begin{array}{l}\text { Well depth } \\
\text { (feet) }\end{array}$ & $\begin{array}{l}\text { Average hydraulic } \\
\text { head (feet above } \\
\text { NGVD of 1929) }\end{array}$ & $\begin{array}{c}\text { Observation } \\
\text { well name }\end{array}$ \\
\hline 431020100243501 & 37N26W16CCBB & Arikaree & 2,530 & -- & 2,523 & TD-79A \\
\hline 430932100262401 & 37N26W19DCC & Ogallala & 2,655 & 160 & 2,584 & -- \\
\hline 430931100251801 & 37N26W20CDD & Arikaree & 2,605 & 140 & 2,557 & -- \\
\hline 430932100211701 & 37N26W23DDCD & Arikaree & 2,538 & 140 & 2,495 & -- \\
\hline 431019100200001 & 37N26W24AAA & Arikaree & 2,471 & 110 & 2,453 & -- \\
\hline 430953100200001 & 37N26W24DAA & Arikaree & 2,451 & 90 & 2,418 & -- \\
\hline 430858100202301 & 37N26W25DBBD & Arikaree & 2,565 & 140 & 2,522 & -- \\
\hline 430851100210801 & 37N26W26DADD & Arikaree & 2,576 & 140 & 2,533 & -- \\
\hline 430756100231601 & 37N26W34CCAA & Arikaree & 2,540 & 140 & 2,521 & -- \\
\hline 430803100212801 & 37N26W35DBDA & Arikaree & 2,554 & 140 & 2,511 & -- \\
\hline 431212100280601 & 37N27W 1CC & Arikaree & 2,474 & 120 & 2,451 & -- \\
\hline 431245100320601 & 37N27W 5A & Arikaree & 2,593 & 60 & 2,582 & -- \\
\hline 431126100321001 & $37 \mathrm{~N} 27 \mathrm{~W} 8 \mathrm{D}$ & Arikaree & 2,553 & 100 & 2,537 & -- \\
\hline 431139100311501 & $37 \mathrm{~N} 27 \mathrm{~W} 9 \mathrm{CAAA}$ & Arikaree & 2,540 & 120 & 2,526 & -- \\
\hline 431050100274501 & 37N27W13BDD & Arikaree & 2,530 & 140 & 2,472 & -- \\
\hline 431051100293101 & 37N27W15ADD & Arikaree & 2,518 & 150 & 2,466 & -- \\
\hline 431027100333001 & $37 \mathrm{~N} 27 \mathrm{~W} 18 \mathrm{DDAB}$ & Ogallala & 2,609 & 53 & 2,605 & RST-17 \\
\hline 431000100325101 & 37N27W20BCD & Arikaree & 2,620 & 80 & 2,609 & -- \\
\hline 430938100273701 & 37N27W24DCB & Arikaree & 2,595 & 165 & 2,548 & -- \\
\hline 430926100290301 & 37N27W26BAB & Arikaree & 2,564 & 250 & 2,442 & -- \\
\hline 430909100333501 & $37 \mathrm{~N} 27 \mathrm{~W} 30 \mathrm{BDDA}$ & Ogallala & 2,722 & 150 & 2,662 & -- \\
\hline 430817100312001 & 37N27W33BD & Arikaree & 2,620 & 120 & 2,604 & -- \\
\hline 431159100412102 & $37 \mathrm{~N} 28 \mathrm{~W} 7 \mathrm{BBBC} 2$ & Arikaree & 2,793 & 243 & 2,718 & -- \\
\hline 431159100412103 & $37 \mathrm{~N} 28 \mathrm{~W} 7 \mathrm{BBBC} 3$ & Ogallala & 2,793 & 98 & 2,716 & -- \\
\hline 431021100384701 & $37 \mathrm{~N} 28 \mathrm{~W} 16 \mathrm{CCDD}$ & Ogallala & 2,744 & 80 & 2,714 & -- \\
\hline 430956100402901 & 37N28W19ACDD & Ogallala & 2,800 & 120 & 2,773 & -- \\
\hline 430932100390001 & $37 \mathrm{~N} 28 \mathrm{~W} 21 \mathrm{CCCC}$ & Ogallala & 2,772 & 163 & 2,727 & TD-76H \\
\hline 430839100373801 & $37 \mathrm{~N} 28 \mathrm{~W} 27 \mathrm{CCCC}$ & Ogallala & 2,805 & 182 & 2,727 & TD-76I \\
\hline 430907100401001 & 37N28W30ADDA & Ogallala & 2,757 & 80 & 2,742 & -- \\
\hline 430922100410302 & 37N28W30BBAA2 & Arikaree & 2,818 & 321 & 2,753 & -- \\
\hline 430842100411301 & 37N28W30CCCB & Ogallala & 2,770 & 184 & 2,745 & TD-76G \\
\hline 430820100371401 & 37N28W34ABDA & Ogallala & 2,783 & 171 & 2,725 & RST-16 \\
\hline 430821100373401 & 37N28W34BCAB & Arikaree & 2,808 & 200 & 2,734 & -- \\
\hline 430809100372401 & 37N28W34BDA (2) & Ogallala & 2,800 & 171 & 2,740 & -- \\
\hline 431212100472901 & $37 \mathrm{~N} 29 \mathrm{~W} 6 \mathrm{DDBD}$ & Ogallala & 2,868 & 237 & 2,740 & -- \\
\hline 431149100462301 & $37 \mathrm{~N} 29 \mathrm{~W} 8 \mathrm{AADC}$ & Arikaree & 2,810 & -- & 2,740 & -- \\
\hline 431138100441601 & $37 \mathrm{~N} 29 \mathrm{~W} 10 \mathrm{DBBB}$ & Ogallala & 2,818 & 150 & 2,756 & -- \\
\hline 431141100422501 & 37N29W12BCDD & Ogallala & 2,825 & 150 & 2,762 & -- \\
\hline 431211100194502 & 37N25W 6CCC2 & Arikaree & 2,369 & 80 & 2,347 & -- \\
\hline 430908100175801 & 37N25W29ACDD & Arikaree & 2,374 & 60 & 2,360 & -- \\
\hline 430757100183301 & $37 \mathrm{~N} 25 \mathrm{~W} 32 \mathrm{CCAB}$ & Arikaree & 2,423 & 124 & 2,396 & -- \\
\hline 431245100210801 & $37 \mathrm{~N} 26 \mathrm{~W} 2 \mathrm{ADAA}$ & Arikaree & 2,383 & 109 & 2,351 & -- \\
\hline 431133100402201 & $37 \mathrm{~N} 29 \mathrm{~W} 13 \mathrm{CBCD}$ & Ogallala & 2,796 & 150 & 2,732 & -- \\
\hline
\end{tabular}


Appendix 1. Wells used for estimating potentiometric surfaces of the Ogallala and Arikaree aquifers.-Continued

[Hydraulic heads are estimated averages for water years 1979-98. NGVD of 1929, National Geodetic Vertical Datum of 1929. --, not applicable or unknown]

\begin{tabular}{|c|c|c|c|c|c|c|}
\hline $\begin{array}{c}\text { Site identification } \\
\text { number }\end{array}$ & Legal location & Aquifer & $\begin{array}{l}\text { Land surface al- } \\
\text { titude (feet above } \\
\text { NGVD of 1929) }\end{array}$ & $\begin{array}{l}\text { Well depth } \\
\text { (feet) }\end{array}$ & $\begin{array}{l}\text { Average hydraulic } \\
\text { head (feet above } \\
\text { NGVD of 1929) }\end{array}$ & $\begin{array}{c}\text { Observation } \\
\text { well name }\end{array}$ \\
\hline 431109100445901 & 37N29W16AAAA & Ogallala & 2,852 & 184 & 2,754 & TD-76A \\
\hline 431100100461601 & 37N29W17AACD & Ogallala & 2,845 & 180 & 2,768 & -- \\
\hline 430959100444001 & $37 \mathrm{~N} 29 \mathrm{~W} 22 \mathrm{CCCC}$ & Arikaree & 2,882 & 265 & 2,781 & TD-80C \\
\hline 430920100444801 & 37N29W27BBCA & Ogallala & 2,877 & 190 & 2,810 & -- \\
\hline 430852100435001 & 37N29W27DACD & Ogallala & 2,825 & 180 & 2,768 & -- \\
\hline 430909100452701 & $37 \mathrm{~N} 29 \mathrm{~W} 28 \mathrm{ACBC}$ & Ogallala & 2,880 & 150 & 2,803 & -- \\
\hline 430840100445601 & 37N29W28DDDD & Ogallala & 2,858 & 195 & 2,791 & TD-76D \\
\hline 430924100460601 & 37N29W29AAAA & Ogallala & 2,868 & 204 & 2,790 & TD-76B \\
\hline 430836100464301 & 37N29W29CDDD & Ogallala & 2,870 & 88 & 2,801 & -- \\
\hline 430755100582301 & 37N29W31DACC & Ogallala & 2,921 & 275 & 2,815 & RST-13 \\
\hline 430748100455601 & $37 \mathrm{~N} 29 \mathrm{~W} 33 \mathrm{CCCC}$ & Ogallala & 2,909 & 203 & 2,817 & TD-76C \\
\hline 431238100490301 & 37N30W 1ACB & Arikaree & 2,740 & 220 & 2,694 & -- \\
\hline 431250100530101 & 37N30W 4BAA & Arikaree & 2,842 & 265 & 2,717 & -- \\
\hline 431122100551202 & 37N30W 7CDBA2 & Arikaree & 2,770 & 187 & 2,604 & -- \\
\hline 431127100532801 & 37N30W 8DACC & Ogallala & 2,880 & 150 & 2,759 & RST-27 \\
\hline 431033100493201 & 37N30W13CBCD & Ogallala & 2,783 & 60 & 2,766 & -- \\
\hline 431022100542301 & 37N30W17CCCB & Arikaree & 2,995 & 386 & 2,789 & -- \\
\hline 430910100490201 & $37 \mathrm{~N} 30 \mathrm{~W} 25 \mathrm{ACBC}$ & Ogallala & 2,899 & 165 & 2,882 & -- \\
\hline 430912100542301 & 37N30W29BCBB & Ogallala & 2,997 & 216 & 2,812 & -- \\
\hline 430848100544001 & 37N30W30DDBC & Ogallala & 2,980 & 272 & 2,778 & -- \\
\hline 430824100522501 & 37N30W33ABD & Arikaree & 2,985 & 265 & 2,839 & -- \\
\hline 430800100491801 & 37N30W36ADCA & Arikaree & 2,935 & 320 & 2,825 & -- \\
\hline 431234100574401 & 37N31W 3ADAC & Arikaree & 2,512 & 42 & 2,506 & -- \\
\hline 431131100580701 & 37N31W10DBBB & Arikaree & 2,530 & 55 & 2,498 & -- \\
\hline 430920100581201 & $37 \mathrm{~N} 31 \mathrm{~W} 22 \mathrm{ABCD} 2$ & Arikaree & 2,943 & 430 & 2,639 & -- \\
\hline 430838100561701 & $37 \mathrm{~N} 31 \mathrm{~W} 25 \mathrm{CC}$ & Arikaree & 3,015 & 370 & 2,802 & -- \\
\hline 430845100571903 & 37N31W26C3 & Arikaree & 3,017 & 350 & 2,737 & -- \\
\hline 430807100591001 & 37N31W33DAA & Arikaree & 3,037 & 445 & 2,781 & -- \\
\hline 430831100580301 & 37N31W34ABAC & Ogallala & 2,970 & 295 & 2,777 & -- \\
\hline 431200101034801 & $37 \mathrm{~N} 32 \mathrm{~W} 11 \mathrm{ABA}$ & Ogallala & 3,060 & 245 & 2,876 & -- \\
\hline 431030101031201 & 37N32W13CAD & Arikaree & 2,970 & 325 & 2,792 & -- \\
\hline 430907101073801 & 37N32W29ACB & Ogallala & 2,910 & 165 & 2,882 & -- \\
\hline 431222101093501 & 37N33W 1DAA & Ogallala & 3,104 & 285 & 3,009 & -- \\
\hline 431148101165001 & 37N33W 7ABD & Ogallala & 3,018 & 260 & 2,947 & -- \\
\hline 431156101105801 & 37N33W11AAB & Ogallala & 3,153 & 305 & 3,032 & -- \\
\hline 431018101132301 & 37N33W16DCDC & Ogallala & 3,023 & 270 & 2,955 & -- \\
\hline 431018101152001 & 37N33W17CCCC & Ogallala & 2,998 & 181 & 2,930 & BT-76C \\
\hline 430929101104202 & 37N33W26AAAA2 & Arikaree & 2,953 & 395 & 2,876 & -- \\
\hline 430929101104203 & 37N33W26AAAA3 & Ogallala & 2,953 & 236 & 2,876 & -- \\
\hline 431432101123401 & 37N33W27BAA & Ogallala & 2,978 & 120 & 2,918 & -- \\
\hline 430836101152201 & 37N33W32BBBB & Ogallala & 2,960 & 185 & 2,895 & -- \\
\hline 430825101151801 & 37N33W32BBBB2 & Ogallala & 2,960 & 143 & 2,902 & BT-80E \\
\hline 431250101163701 & 37N34W 1AAAA & Ogallala & 3,113 & 245 & 2,960 & -- \\
\hline
\end{tabular}


Appendix 1. Wells used for estimating potentiometric surfaces of the Ogallala and Arikaree aquifers.-Continued

[Hydraulic heads are estimated averages for water years 1979-98. NGVD of 1929, National Geodetic Vertical Datum of 1929. --, not applicable or unknown]

\begin{tabular}{|c|c|c|c|c|c|c|}
\hline $\begin{array}{c}\text { Site identification } \\
\text { number }\end{array}$ & Legal location & Aquifer & $\begin{array}{l}\text { Land surface al- } \\
\text { titude (feet above } \\
\text { NGVD of 1929) }\end{array}$ & $\begin{array}{l}\text { Well depth } \\
\text { (feet) }\end{array}$ & $\begin{array}{l}\text { Average hydraulic } \\
\text { head (feet above } \\
\text { NGVD of 1929) }\end{array}$ & $\begin{array}{c}\text { Observation } \\
\text { well name }\end{array}$ \\
\hline 431540100154501 & 38N25W15DCCB & Ogallala & 2,467 & 110 & 2,406 & -- \\
\hline 431509100185901 & $38 \mathrm{~N} 25 \mathrm{~W} 19 \mathrm{ADCC}$ & Ogallala & 2,530 & 80 & 2,504 & -- \\
\hline 431430100195901 & $38 \mathrm{~N} 25 \mathrm{~W} 30 \mathrm{BCBB}$ & Arikaree & 2,483 & 144 & 2,458 & TD-80D \\
\hline 431311100193201 & 38N25W31CDBA & Arikaree & 2,426 & 56 & 2,414 & -- \\
\hline 431327100164501 & 38N25W33ACD & Ogallala & 2,475 & 24 & 2,466 & -- \\
\hline 431637100264101 & $38 \mathrm{~N} 26 \mathrm{~W} 7 \mathrm{CDB}$ & Arikaree & 2,513 & 90 & 2,486 & -- \\
\hline 431716100212001 & 38N26W11AAB & Ogallala & 2,651 & 160 & 2,601 & -- \\
\hline 431554100203301 & $38 \mathrm{~N} 26 \mathrm{~W} 13 \mathrm{BCCA}$ & Arikaree & 2,608 & 230 & 2,505 & -- \\
\hline 431532100200101 & $38 \mathrm{~N} 26 \mathrm{~W} 24 \mathrm{AAAB}$ & Ogallala & 2,503 & 85 & 2,467 & -- \\
\hline 431413100244901 & 38N26W29DAA & Arikaree & 2,440 & 90 & 2,418 & -- \\
\hline 431356100255401 & 38N26W30DAD & Arikaree & 2,420 & 90 & 2,388 & -- \\
\hline 431340100253901 & 38N26W32BBD & Arikaree & 2,452 & 85 & 2,437 & -- \\
\hline 431328100240901 & 38N26W33BDD & Arikaree & 2,424 & 70 & 2,413 & -- \\
\hline 431308100223101 & 38N26W34DDB & Arikaree & 2,417 & 100 & 2,395 & -- \\
\hline 431323100213501 & 38N26W35DBBA & Arikaree & 2,403 & 100 & 2,341 & -- \\
\hline 431736100293201 & $38 \mathrm{~N} 27 \mathrm{~W} 3 \mathrm{DAD}$ & Arikaree & 2,526 & 100 & 2,474 & -- \\
\hline 431808100312801 & $38 \mathrm{~N} 27 \mathrm{~W} 4 \mathrm{BAB}$ & Arikaree & 2,550 & 100 & 2,489 & -- \\
\hline 431757100323302 & $38 \mathrm{~N} 27 \mathrm{~W} 5 \mathrm{BDAB}$ & Arikaree & 2,522 & 100 & 2,497 & -- \\
\hline 431650100330701 & $38 \mathrm{~N} 27 \mathrm{~W} 7 \mathrm{DAAB}$ & Arikaree & 2,477 & -- & 2,468 & -- \\
\hline 431548100314401 & $38 \mathrm{~N} 27 \mathrm{~W} 16 \mathrm{CBCD}$ & Arikaree & 2,484 & 90 & 2,453 & -- \\
\hline 431440100275301 & $38 \mathrm{~N} 27 \mathrm{~W} 25 \mathrm{BABA}$ & Arikaree & 2,448 & 100 & 2,416 & -- \\
\hline 431430100320101 & $38 \mathrm{~N} 27 \mathrm{~W} 28 \mathrm{~B}$ & Arikaree & 2,518 & 110 & 2,507 & -- \\
\hline 431337100312101 & 38N27W33BDA & Arikaree & 2,570 & 130 & 2,541 & -- \\
\hline 431539100352401 & $38 \mathrm{~N} 28 \mathrm{~W} 13 \mathrm{CCCC}$ & Arikaree & 2,577 & -- & 2,539 & -- \\
\hline 431625100361301 & 38N28W14BAAB & Arikaree & 2,589 & 115 & 2,529 & -- \\
\hline 431615100390701 & 38N28W17AADD & Arikaree & 2,664 & -- & 2,610 & -- \\
\hline 431625100411801 & $38 \mathrm{~N} 28 \mathrm{~W} 18 \mathrm{BBBA}$ & Arikaree & 2,596 & -- & 2,587 & -- \\
\hline 431512100402501 & 38N28W19ADCD & Arikaree & 2,673 & -- & 2,639 & -- \\
\hline 431714100364101 & 38N28W20AAAD & Ogallala & 2,700 & -- & 2,646 & -- \\
\hline 431506100363601 & $38 \mathrm{~N} 28 \mathrm{~W} 23 \mathrm{CBBB}$ & Arikaree & 2,635 & -- & 2,627 & -- \\
\hline 431430100371601 & 38N28W27ACB & Arikaree & 2,768 & 220 & 2,724 & -- \\
\hline 431427100375201 & $38 \mathrm{~N} 28 \mathrm{~W} 28 \mathrm{ADAA}$ & Ogallala & 2,781 & -- & 2,729 & -- \\
\hline 431354100375201 & 38N28W28DDDD & Ogallala & 2,781 & -- & 2,750 & -- \\
\hline 431347100404901 & $38 \mathrm{~N} 28 \mathrm{~W} 31 \mathrm{ABBB}$ & Arikaree & 2,666 & 120 & 2,645 & -- \\
\hline 431342100344101 & $38 \mathrm{~N} 28 \mathrm{~W} 36 \mathrm{ABCB}$ & Arikaree & 2,620 & 73 & 2,609 & RST-15 \\
\hline 431551100441601 & 38N29W15DBCD & Arikaree & 2,696 & -- & 2,699 & -- \\
\hline 431536100472201 & $38 \mathrm{~N} 29 \mathrm{~W} 17 \mathrm{BCDA}$ & Arikaree & 2,687 & 100 & 2,670 & -- \\
\hline 431502100443801 & 38N29W22CAC & Arikaree & 2,730 & 160 & 2,686 & -- \\
\hline 431435100414101 & $38 \mathrm{~N} 29 \mathrm{~W} 25 \mathrm{AACB}$ & Ogallala & 2,663 & -- & 2,647 & -- \\
\hline 431424100430601 & 38N29W26ACB & Arikaree & 2,750 & 220 & 2,671 & -- \\
\hline 431340100430401 & $38 \mathrm{~N} 29 \mathrm{~W} 35 \mathrm{ACBB}$ & Arikaree & 2,803 & 370 & 2,708 & -- \\
\hline 431809100483401 & $38 \mathrm{~N} 30 \mathrm{~W} 1 \mathrm{AAAA}$ & Arikaree & 2,763 & 180 & 2,626 & -- \\
\hline 431740100502201 & 38N30W 2CAA & Arikaree & 2,640 & 265 & 2,492 & -- \\
\hline
\end{tabular}


Appendix 1. Wells used for estimating potentiometric surfaces of the Ogallala and Arikaree aquifers.-Continued

[Hydraulic heads are estimated averages for water years 1979-98. NGVD of 1929, National Geodetic Vertical Datum of 1929. --, not applicable or unknown]

\begin{tabular}{|c|c|c|c|c|c|c|}
\hline $\begin{array}{c}\text { Site identification } \\
\text { number }\end{array}$ & Legal location & Aquifer & $\begin{array}{l}\text { Land surface al- } \\
\text { titude (feet above } \\
\text { NGVD of 1929) }\end{array}$ & $\begin{array}{l}\text { Well depth } \\
\text { (feet) }\end{array}$ & $\begin{array}{l}\text { Average hydraulic } \\
\text { head (feet above } \\
\text { NGVD of 1929) }\end{array}$ & $\begin{array}{c}\text { Observation } \\
\text { well name }\end{array}$ \\
\hline 431610100484701 & 38N30W13ADBB & Arikaree & 2,645 & 119 & 2,632 & -- \\
\hline 431537100504701 & $38 \mathrm{~N} 30 \mathrm{~W} 14 \mathrm{CCCA}$ & Arikaree & 2,723 & 280 & 2,639 & -- \\
\hline 431601100514301 & 38N30W15BDC & Arikaree & 2,650 & 158 & 2,650 & -- \\
\hline 431612100551201 & $38 \mathrm{~N} 30 \mathrm{~W} 18 \mathrm{BADB}$ & Arikaree & 2,550 & 245 & 2,416 & -- \\
\hline 431515100501701 & $38 \mathrm{~N} 30 \mathrm{~W} 23 \mathrm{ACBC}$ & Arikaree & 2,720 & 258 & 2,657 & -- \\
\hline 431255100545701 & 38N30W31DCCD & Arikaree & 2,872 & 250 & 2,701 & -- \\
\hline 431315100541301 & 38N30W32CBD & Arikaree & 2,887 & 265 & 2,736 & -- \\
\hline 431318100532301 & 38N30W32DAAB & Ogallala & 2,838 & 47 & 2,818 & -- \\
\hline 431340100521405 & 38N30W33AA5 & Arikaree & 2,840 & 238 & 2,624 & -- \\
\hline 431335100511101 & 38 N30W34A & Arikaree & 2,600 & -- & 2,573 & -- \\
\hline 431252100501801 & 38N30W35BDDB & Arikaree & 2,708 & 219 & 2,605 & -- \\
\hline 431744100561401 & $38 \mathrm{~N} 31 \mathrm{~W} 1 \mathrm{BACB} 2$ & Arikaree & 2,600 & 160 & 2,502 & -- \\
\hline 431744100583601 & $38 \mathrm{~N} 31 \mathrm{~W} 3 \mathrm{ABAB}$ & Arikaree & 2,692 & 200 & 2,601 & -- \\
\hline 431733100585701 & $38 \mathrm{~N} 31 \mathrm{~W} 4 \mathrm{DABD} 2$ & Arikaree & 2,725 & 226 & 2,656 & -- \\
\hline 431623101010501 & $38 \mathrm{~N} 31 \mathrm{~W} 8 \mathrm{CCC}$ & Arikaree & 2,787 & 93 & 2,732 & -- \\
\hline 431654100574302 & $38 \mathrm{~N} 31 \mathrm{~W} 10 \mathrm{ADAC} 2$ & Arikaree & 2,698 & 210 & 2,606 & -- \\
\hline 431630100570201 & 38N31W11CDAA & Arikaree & 2,652 & 240 & 2,553 & -- \\
\hline 431550100590501 & 38N31W16CABD (2) & Ogallala & 2,747 & 20 & 2,743 & -- \\
\hline 431520100593601 & 38N31W16DBAA & Arikaree & 2,710 & 128 & 2,688 & -- \\
\hline 431551101003901 & 38N31W17CAA & Arikaree & 2,880 & 180 & 2,878 & -- \\
\hline 431501101005701 & $38 \mathrm{~N} 31 \mathrm{~W} 20 \mathrm{CBAA}$ & Arikaree & 2,837 & 140 & 2,827 & -- \\
\hline 431526100563202 & 38N31W23AAAB2 R & Arikaree & 2,443 & 60 & 2,431 & -- \\
\hline 431508100562101 & 38N31W24BDAD R & Arikaree & 2,605 & 262 & 2,505 & -- \\
\hline 431427100561201 & $38 \mathrm{~N} 31 \mathrm{~W} 25 \mathrm{BBAC}$ & Arikaree & 2,722 & 360 & 2,563 & -- \\
\hline 431259100574401 & $38 \mathrm{~N} 31 \mathrm{~W} 34 \mathrm{DDAC}$ & Arikaree & 2,502 & 85 & 2,477 & -- \\
\hline 431338100570901 & 38N31W35BA & Arikaree & 2,485 & 60 & 2,476 & -- \\
\hline 431738103035702 & $38 \mathrm{~N} 32 \mathrm{~W} 1 \mathrm{BAAC}$ & Arikaree & 2,750 & 262 & 2,671 & -- \\
\hline 431740101044601 & 38N32W 3ADDD & Arikaree & 2,750 & 205 & 2,681 & -- \\
\hline 431637101084802 & $38 \mathrm{~N} 32 \mathrm{~W} 7 \mathrm{DCAB} 2$ & Arikaree & 2,890 & 152 & 2,841 & -- \\
\hline 431639101043102 & 38N32W11CBD2 & Arikaree & 2,785 & 225 & 2,716 & -- \\
\hline 431554101044501 & $38 \mathrm{~N} 32 \mathrm{~W} 15 \mathrm{DAAA}$ & Arikaree & 2,805 & 90 & 2,782 & -- \\
\hline 431533101080501 & 38N32W17CCD & Arikaree & 3,059 & 154 & 2,907 & -- \\
\hline 431303101075401 & $38 \mathrm{~N} 32 \mathrm{~W} 32 \mathrm{CDB}$ & Arikaree & 3,032 & 285 & 2,926 & -- \\
\hline 431625101103001 & $38 \mathrm{~N} 33 \mathrm{~W} 12 \mathrm{CCDC}$ & Arikaree & 2,943 & 150 & 2,931 & -- \\
\hline 431843100263301 & 39N26W31BDA & Arikaree & 2,600 & 140 & 2,543 & -- \\
\hline 431830100250201 & 39N26W32DCDA & Arikaree & 2,533 & 153 & 2,457 & -- \\
\hline 432242100281201 & 39N27W 1CCB & Arikaree & 2,520 & 80 & 2,479 & -- \\
\hline 432316100305801 & 39N27W 3BBD & Arikaree & 2,500 & 65 & 2,469 & -- \\
\hline 432205100294301 & 39N27W10DABB & Arikaree & 2,513 & 75 & 2,482 & -- \\
\hline 432033100305601 & 39N27W21ADDA & Arikaree & 2,754 & 220 & 2,583 & -- \\
\hline 432009100290301 & 39N27W23CDBA & Arikaree & 2,651 & 130 & 2,610 & -- \\
\hline 431937100320101 & 39N27W29ADBD & Arikaree & 2,676 & 130 & 2,645 & -- \\
\hline 431815100341801 & 39N27W31CCC & Arikaree & 2,537 & 160 & 2,477 & -- \\
\hline 431818100324201 & $39 \mathrm{~N} 27 \mathrm{~W} 32 \mathrm{CDCB} 2$ & Arikaree & 2,544 & 90 & 2,513 & -- \\
\hline
\end{tabular}


Appendix 1. Wells used for estimating potentiometric surfaces of the Ogallala and Arikaree aquifers. - Continued [Hydraulic heads are estimated averages for water years 1979-98. NGVD of 1929, National Geodetic Vertical Datum of 1929. --, not applicable or unknown]

\begin{tabular}{|c|c|c|c|c|c|c|}
\hline $\begin{array}{c}\text { Site identification } \\
\text { number }\end{array}$ & Legal location & Aquifer & $\begin{array}{l}\text { Land surface al- } \\
\text { titude (feet above } \\
\text { NGVD of 1929) }\end{array}$ & $\begin{array}{l}\text { Well depth } \\
\text { (feet) }\end{array}$ & $\begin{array}{c}\text { Average hydraulic } \\
\text { head (feet above } \\
\text { NGVD of 1929) }\end{array}$ & $\begin{array}{c}\text { Observation } \\
\text { well name }\end{array}$ \\
\hline 431814100302602 & 39N27W34CCDC2 & Arikaree & 2,562 & 80 & 2,536 & -- \\
\hline 431903100282002 & 39N27W35AAAB2 & Arikaree & 2,598 & 91 & 2,552 & -- \\
\hline 432150100381701 & 39N28W 9DCA & Arikaree & 2,518 & 68 & 2,506 & -- \\
\hline 432203100361301 & 39N28W11CAA & Arikaree & 2,535 & 160 & 2,510 & -- \\
\hline 432117100371601 & 39N28W15ACC & Arikaree & 2,585 & 160 & 2,525 & -- \\
\hline 432108100400001 & 39N28W17CBD & Arikaree & 2,683 & 210 & 2,616 & -- \\
\hline 432003100352501 & $39 \mathrm{~N} 28 \mathrm{~W} 24 \mathrm{CC}$ & Arikaree & 2,675 & 150 & 2,615 & -- \\
\hline 431907100350201 & $39 \mathrm{~N} 28 \mathrm{~W} 25 \mathrm{CCD}$ & Arikaree & 2,565 & 150 & 2,505 & -- \\
\hline 431947100354001 & 39N28W26AADB & Arikaree & 2,628 & 150 & 2,568 & -- \\
\hline 431927100381501 & 39N28W28DBAA & Arikaree & 2,628 & 140 & 2,599 & -- \\
\hline 431949100392901 & 39N28W29ABAD & Arikaree & 2,634 & 150 & 2,625 & -- \\
\hline 431933100412101 & 39N28W30BCDB & Arikaree & 2,622 & 150 & 2,603 & -- \\
\hline 431912100410501 & 39N28W30CDBD & Arikaree & 2,601 & 150 & 2,587 & -- \\
\hline 431812100383901 & 39N28W33CDD & Arikaree & 2,563 & 140 & 2,521 & -- \\
\hline 432049100415301 & 39N29W13CC & Arikaree & 2,640 & 200 & 2,585 & -- \\
\hline 432025100434001 & 39N29W23BCD & Arikaree & 2,500 & 112 & 2,469 & -- \\
\hline 431830100450901 & 39N29W33DA & Arikaree & 2,657 & 140 & 2,629 & -- \\
\hline 431822100424301 & 39N29W35DDAB & Arikaree & 2,681 & -- & 2,648 & -- \\
\hline 431813100413101 & 39N29W36DDDC & Arikaree & 2,645 & 220 & 2,597 & -- \\
\hline 432244100594502 & 39N31W 4CBDB2 & Arikaree & 2,467 & 60 & 2,449 & -- \\
\hline 432149101005001 & 39N31W 8CACB & Arikaree & 2,653 & 274 & 2,517 & -- \\
\hline 432020101010901 & 39N31W19ACDA2 & Arikaree & 2,625 & 300 & 2,545 & -- \\
\hline 431903100561701 & 39N31W25CCCA & Arikaree & 2,558 & 170 & 2,471 & -- \\
\hline 431933101010501 & 39N31W29BCB & Arikaree & 2,640 & 240 & 2,586 & -- \\
\hline 431823101005201 & $39 \mathrm{~N} 31 \mathrm{~W} 32 \mathrm{CBDB}$ & Arikaree & 2,685 & 198 & 2,646 & -- \\
\hline 431813100571001 & 39N31W35CDBD & Arikaree & 2,620 & 200 & 2,534 & -- \\
\hline 432310101045501 & 39N32W 3AAAA & Arikaree & 2,610 & 125 & 2,578 & TD-80A \\
\hline 432205101032201 & $39 \mathrm{~N} 32 \mathrm{~W} 11 \mathrm{ACDA}$ & Arikaree & 2,595 & 125 & 2,585 & -- \\
\hline 432131101034001 & 39N32W14AAA & Arikaree & 2,634 & 125 & 2,600 & -- \\
\hline 432131101053001 & $39 \mathrm{~N} 32 \mathrm{~W} 15 \mathrm{BAB}$ & Arikaree & 2,678 & 200 & 2,639 & -- \\
\hline 431922101032201 & $39 \mathrm{~N} 32 \mathrm{~W} 25 \mathrm{CBAB}$ & Arikaree & 2,705 & 180 & 2,626 & -- \\
\hline 431913101084001 & 39N32W30DBDC & Arikaree & 2,820 & 138 & 2,768 & -- \\
\hline 431820101045002 & 39N32W34DADC2 & Arikaree & 2,781 & 300 & 2,646 & -- \\
\hline 432044101115201 & 39N33W15DDDD & Arikaree & 2,800 & 360 & 2,764 & TD-79D \\
\hline 432416100315601 & 40N27W32AAA & Arikaree & 2,478 & 16 & 2,470 & -- \\
\hline 432540101092202 & 40N32W19BCC2 & Arikaree & 2,595 & 100 & 2,570 & -- \\
\hline 432515101071701 & 40N32W20DDBB & Arikaree & 2,597 & 220 & 2,586 & -- \\
\hline 432554101065601 & $40 \mathrm{~N} 32 \mathrm{~W} 21 \mathrm{BBBB}$ & Arikaree & 2,576 & 163 & 2,561 & MT-78A \\
\hline 432530101024801 & 40N32W24CBB & Arikaree & 2,568 & 152 & 2,543 & -- \\
\hline 432453101075601 & 40N32W29BCAB & Arikaree & 2,618 & 240 & 2,600 & -- \\
\hline 432654101130401 & 40N33W 9DDDA & Arikaree & 2,570 & 120 & 2,516 & -- \\
\hline 432545101102701 & 40N33W24BBDD & Arikaree & 2,548 & 108 & 2,523 & -- \\
\hline 432446101131104 & 40N33W28AD & Arikaree & 2,740 & 110 & 2,686 & -- \\
\hline 432407101131201 & 40N33W33AAB & Arikaree & 2,742 & 225 & 2,686 & -- \\
\hline
\end{tabular}


Publishing support provided by:

Rolla and Lafayette Publishing Service Centers

For more information concerning this publication, contact:

Director, South Dakota Water Science Center

1608 Mt. View Rd.

Rapid City, South Dakota 57702

(605) 394-3200

Or visit the South Dakota Water Science Center Web site at: http://sd.water.usgs.gov/ 


